\title{
Concepts for Reuse and Recycling of Construction and Demolition Waste
}

by

Patrick J. Dolan, Richard G. Lampo, and Jacqueline C. Dearborn

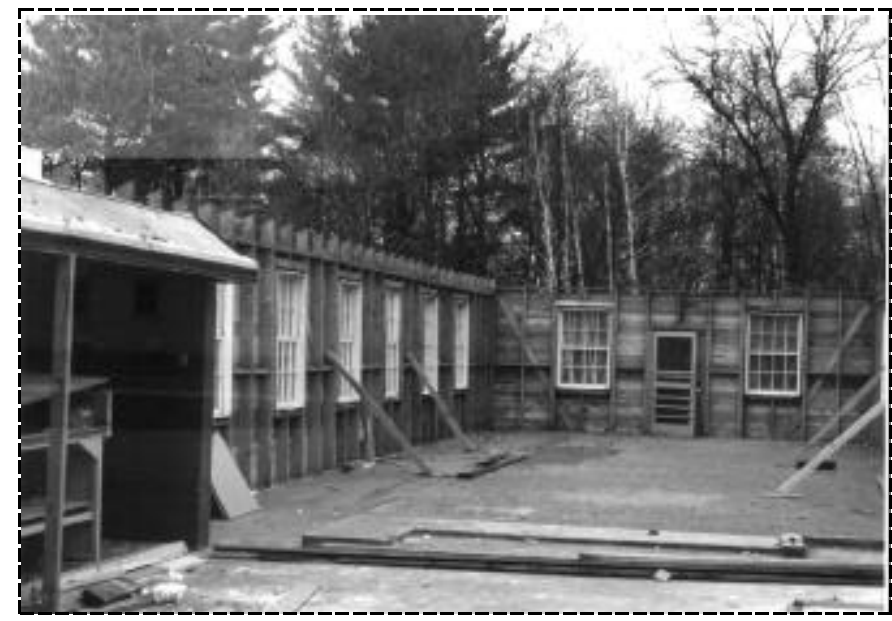

Wood-framed

barracks in

process of

deconstruction.

The U.S. Army engages in a great number of construction, renovation, and demolition projects across the nation. A significant amount of debris resulting from these activities is currently disposed of in landfills. Landfilling this debris results in a large burden on the world's natural resources and an increasingly expensive problem for solid waste management. Throughout the United States, construction and demolition (C\&D) waste accounts for an estimated 35 to 40 percent of the municipal solid waste (MSW) stream.

This research project: (1) identified the primary opportunities, constraints, and means to divert C\&D debris from the solid waste stream, (2) evaluated C\&D material recycling technologies and materials,
(3) identified construction materials from existing facilities that may be directly salvaged or reused without substantial alteration or reprocessing, and (4) developed guidelines that project managers can use to organize a construction project recycling program.

This report presents an innovative approach to construction and demolition waste management. The current level of construction and demolition in the Army, and also any programs, regulations, or policies that may affect the level of construction in the future are addressed and provide the justification for increasing the level of recycling C\&D waste on military installations. 
SF 298 


\section{Foreword}

This study was conducted for Headquarters, U.S. Army Corps of Engineers (HQUSACE) under Project 4A162784AT41, "Military Facilities Engineering Technology"; Work Unit FL-C07, "Construction and Demolition Waste." The technical monitors were Daniel Chen, CEMP-ET, and Malcolm McLeod, CECPWES.

The work was performed by the Materials and Structures Branch (CF-M), of the Facilities Division (CF), Construction Engineering Research Laboratory (CERL). The CERL Principal Investigator was Richard G. Lampo. Special appreciation is owed to Stephen Cosper, CECER-CN-E, and Art Davey, Fort McCoy Directorate of Public Works for technical input into this project and report. Patrick Dolan and J acqueline Dearborn were student contractors, and Charles Lozar was a commercial contractor asociated with this project. I lker R. Adiguzel is Chief, CECE R-CF-M and L. Michael Golish is Chief, CECER-CF. The technical editor was William J . Wolfe, Information Technology Laboratory.

The Director of CERL is Dr. Michael J . O'Connor. 


\section{Contents}

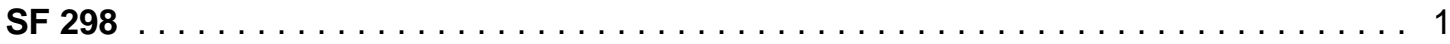

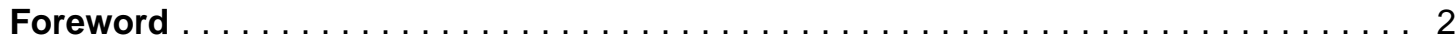

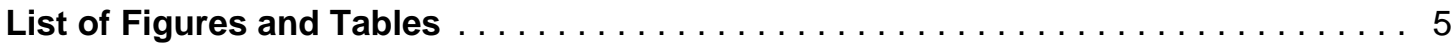

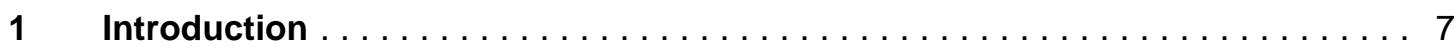

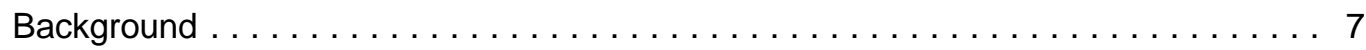

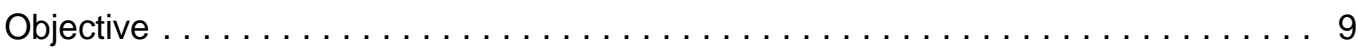

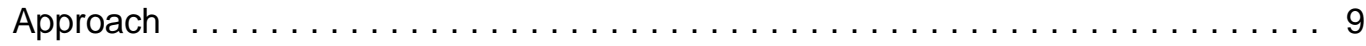

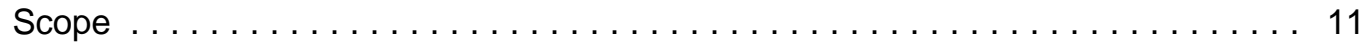

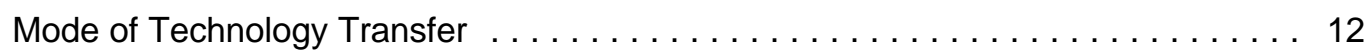

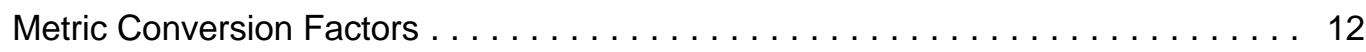

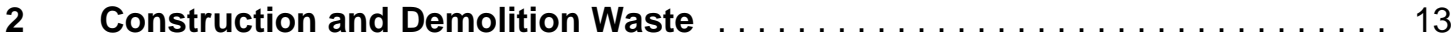

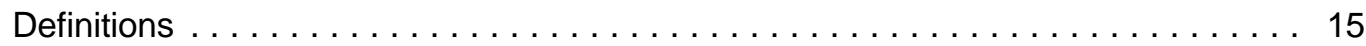

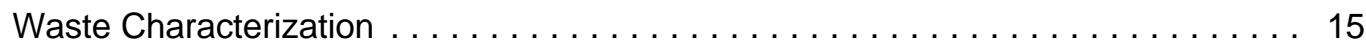

Current Waste Stream . . . . . . . . . . . . . . . . . . . . . . . . . 21

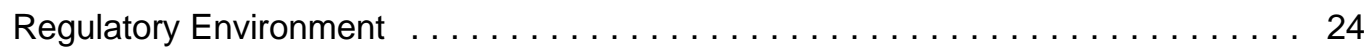

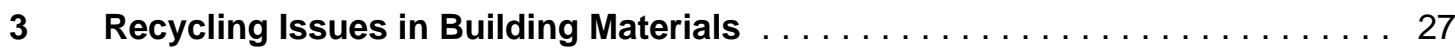

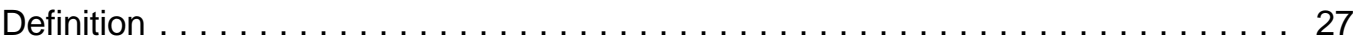

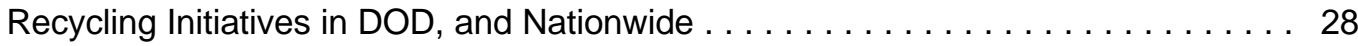

Barriers to Recycling . . . . . . . . . . . . . . . . . . . . . 29

Benefits of Recycling C\&D Waste $\ldots \ldots \ldots \ldots \ldots \ldots \ldots \ldots \ldots \ldots \ldots \ldots \ldots \ldots \ldots \ldots \ldots \ldots \ldots$

Managing Construction/Demolition Site Recycling Operations . . . . . . . . . . 34

Incentives To Recycle $\ldots \ldots \ldots \ldots \ldots \ldots \ldots \ldots \ldots \ldots \ldots \ldots \ldots \ldots \ldots \ldots$

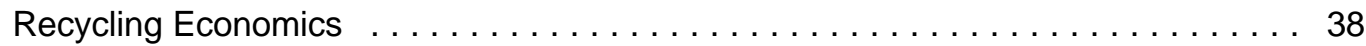

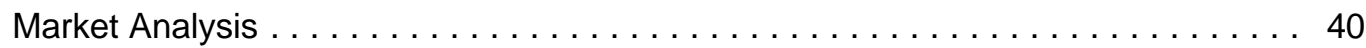

$4 \quad$ Salvaged Building Materials and Systems $\ldots \ldots \ldots \ldots \ldots \ldots \ldots \ldots \ldots$

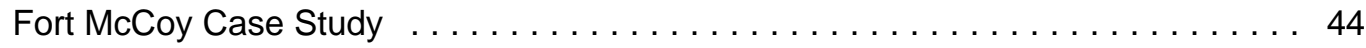

Project Planning for Salvage Operations $\ldots \ldots \ldots \ldots \ldots \ldots \ldots \ldots \ldots \ldots$

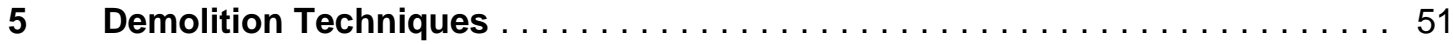

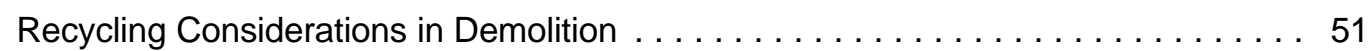

Criteria for System Selection and Evaluation $\ldots \ldots \ldots \ldots \ldots \ldots \ldots \ldots \ldots \ldots$ 


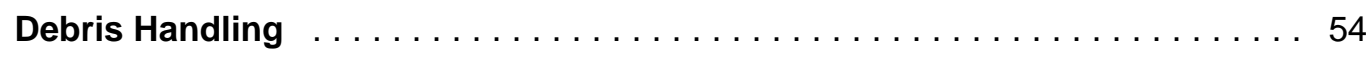

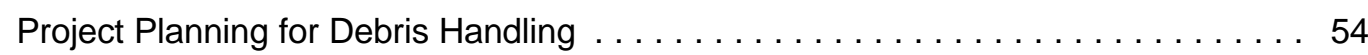

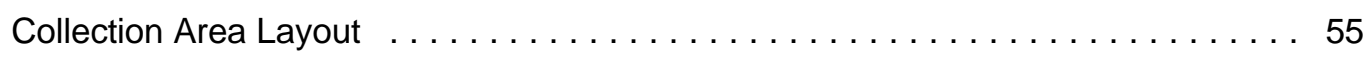

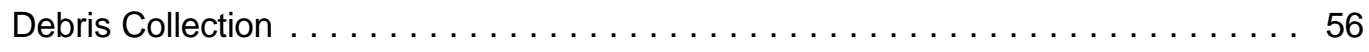

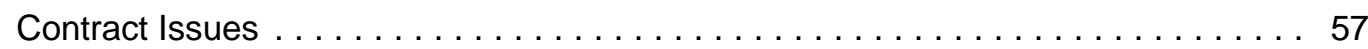

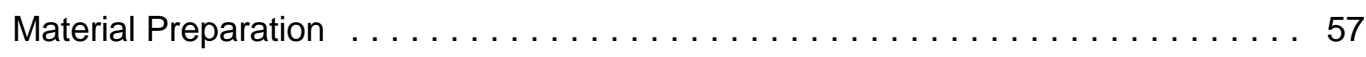

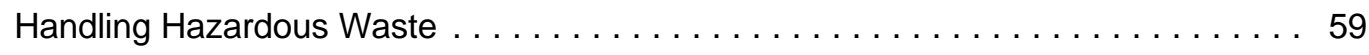

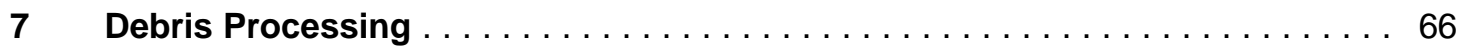

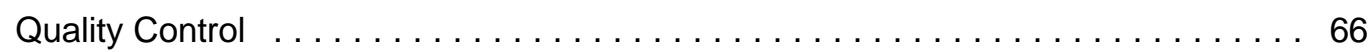

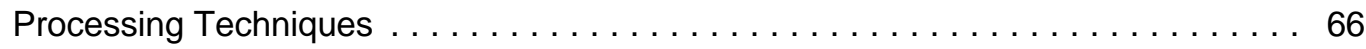

Criteria for Choosing Processing Equipment $\ldots \ldots \ldots \ldots \ldots \ldots \ldots \ldots \ldots$

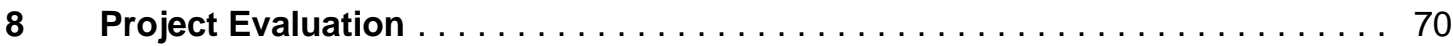

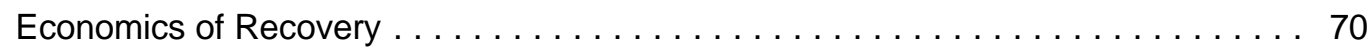

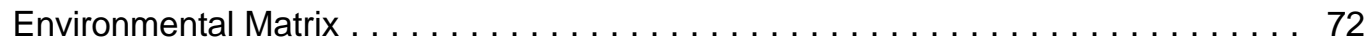

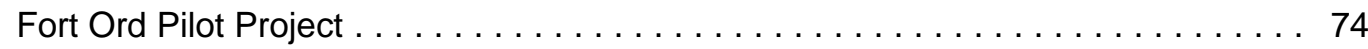

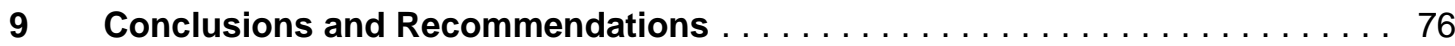

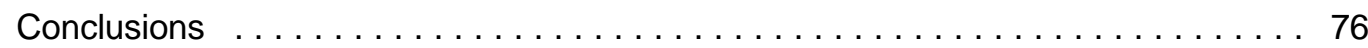

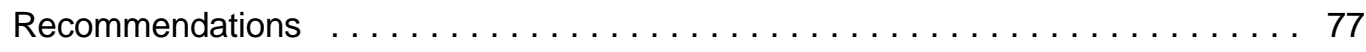

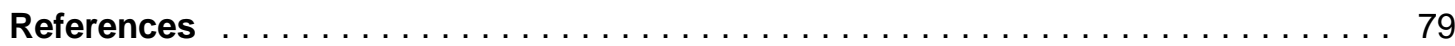

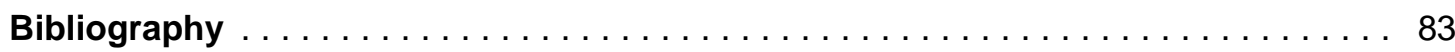

Appendix A: Catalog of Recyclable Building Materials $\ldots \ldots \ldots \ldots \ldots \ldots$

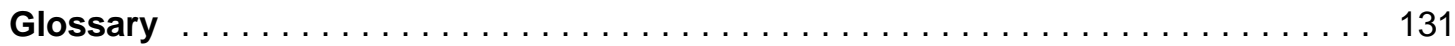

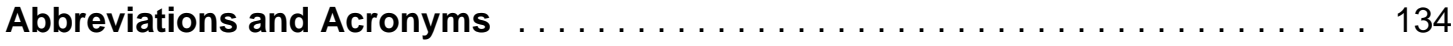

Distribution 


\section{List of Figures and Tables}

\section{Figures}

1 Heavy equipment being used to smash and compact building material. . . . . 7

2 Development of a recycling plan. $\ldots \ldots \ldots \ldots \ldots \ldots \ldots \ldots$

3 Use of materials and C\&D waste generation in the life cycle of buildings. . . . . 13

$4 \quad$ C\&D waste recycling action plan. $\ldots \ldots \ldots \ldots \ldots \ldots \ldots \ldots \ldots \ldots \ldots \ldots$

5 Worksheet for determining waste sales economic analysis (Adapted from Department of the Army Technical Manual 5-634). . . . . . . . . . . 41

$6 \quad$ Wood-framed barracks in process of deconstruction. . . . . . . . . . 47

$7 \quad$ Wood-framed mess hall in process of deconstruction. $\ldots \ldots \ldots \ldots \ldots \ldots 4$

8 Equipment used to grind building foundation materials for future use on

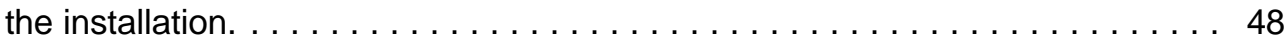

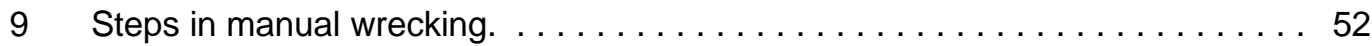

10 Flow chart for determining status of lead paint waste. $\ldots \ldots \ldots \ldots \ldots 61$

11 Flow chart for asbestos demolition/renovation. . . . . . . . . . . 64

12 Demolition debris being loaded into debris compactor. . . . . . . . . 67

A1 Representative recycling asphalt paving processing plant. . . . . . . 95

A2 Representative concrete processing plant. . . . . . . . . . . . . 109

A3 Flow of drywall waste through a representative gypsum processing plant. $\ldots 117$

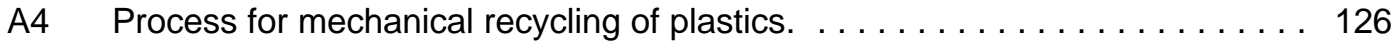

A5 Flow of materials through a representative wood waste processing plant. . . 128 


\section{Tables}

1 Common components of construction and demolition activi-

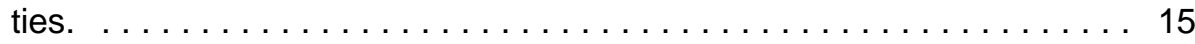

$2 \quad$ C\&D waste material categories and sources. $\ldots \ldots \ldots \ldots \ldots \ldots$

$3 \quad$ Volume-weight conversions. . . . . . . . . . . . . . 20

$4 \quad$ Typical densities for construction material. . . . . . . . . . . . . . . 22

$5 \quad$ Cost savings with Fort McCoy WWII salvage program. . . . . . . . 48

$6 \quad$ Mechanical demolition techniques and equipment. ........... 52

$7 \quad$ Possible hazardous contaminants in C\&D waste. . . . . . . . . . . . 65

$8 \quad$ Costs and benefits of disposal and recovery. $\ldots \ldots \ldots \ldots \ldots \ldots$

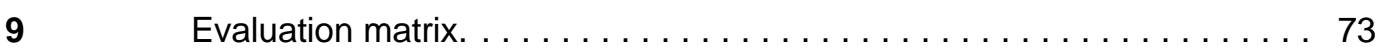

$10 \quad$ Scores for reuse, recycling, and price. $\ldots \ldots \ldots \ldots \ldots \ldots \ldots$

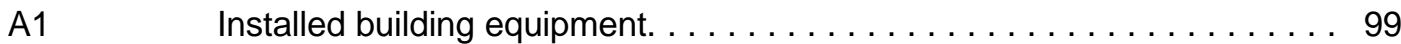

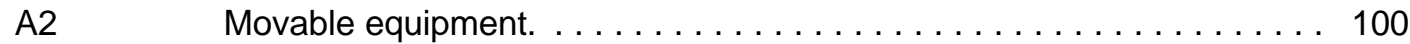

A3 Proportionate quantity of concrete in various floor systems. . . . . . 106

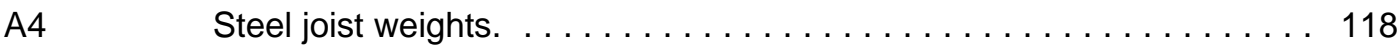




\section{Introduction}

\section{Background}

The U.S. Army engages in a great number of construction, renovation, and demolition projects across the nation. A significant amount of debris resulting from these activities, including concrete, wood, and metals is currently disposed of in landfills. Landfilling this debris results in a large burden on the world's natural resources and an increasingly expensive problem for solid wastemanagement. The problem is widespread throughout the United States, with construction and demolition (C\&D) waste accounting for an estimated 35 to 40 percent of the municipal solid waste (MSW) stream (Brickner 1997). Figure 1 shows a typical "smash and trash" operation for demolition. This research project will explore alternatives to the outright disposal of C\&D waste in landfills.

The most important issue that forms the basis of this project is that the amount of construction and demolition waste on Department of the Army (DA) installations is expected to increase in the near future. The Army's efforts to reduce unnecessary

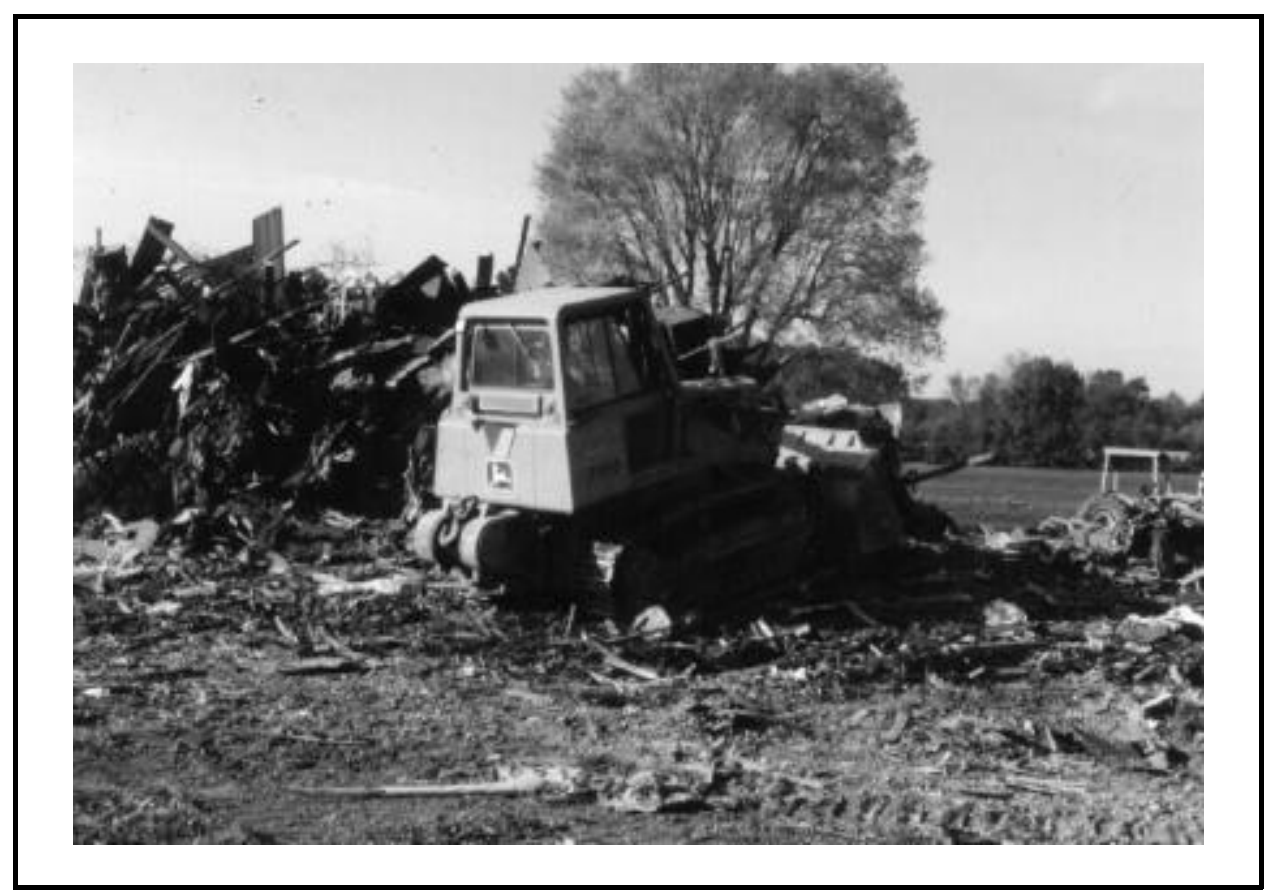

Figure 1. Heavy equipment being used to smash and compact building material. 
infrastructure began with the Defense Secretary's Commission on Base Realignments and Closures (BRAC) in 1988. Construction, renovation, and demolition activities will significantly increaseduring the continued BRAC program. The 1995 BRAC program, coupled with the previously approved closures, will reduce the domestic base structure by about 21 percent. The DA's Facilities Reduction Program alone had the goal to reduce Army facilities 27 percent by Fiscal Year 1996.

Installations continue to maintain excess and/or obsol ete structures due to lack of funds to dispose of them. Disposal/demolition of these structures will cut costs and improve safety. Approximately 80 million excess square feet, including more than 8,000 specific structures, have been identified as excess and/or obsolete structures. Under Defense Reform I nitiative Directive (DRID) \#36 - Disposal/ Demolition of Excess Structures (1998), military departments, beginning in 1998, are directed to meet the following disposal/demolition targets (in millions of feet) by the end of the year indicated:

\begin{tabular}{|l|l|r|}
\hline & Year & \multicolumn{1}{|c|}{ MSF } \\
\hline Army & FY03 & 53.2 \\
\hline Navy & FY02 & 9.9 \\
\hline Air Force & FY03 & 14.9 \\
\hline Marine & FY00 & 2.1 \\
\hline
\end{tabular}

Besides the facility reduction programs, other important issues include: the increased replacement of infrastructure on military installations; the occurrence of catastrophic natural disasters, such as Hurricane Andrew and the recent flooding of the Mississippi River valley; the increasing cost of conventional disposal of $C \& D$ waste; and stricter Federal and State C\&D landfill regulations.

Thereareseveral barriers to recycling construction and demolition waste. Themost significant barrier is the potential inability on the part of project managers and solid waste authorities to identify markets for the debris. Another barrier is the difficulty in accurately characterizing $C \& D$ waste. Construction and demolition waste is highly variable in both content and quantity. This variability is due to the nature of the waste, the dispersion of $C \& D$ activities, inconsistent waste management regulations, range of disposal options, and the variance in cost of disposal options. 


\section{Objective}

The objective of this study was to develop concepts for the reutilization of construction materials, including waste debris, by means of recycling into other components that are useful in construction. This study: (1) identified the primary opportunities, constraints, and means to divert $C \& D$ debris from the solid waste stream, (2) evaluated C\&D material recycling technologies and materials, (3) identified construction materials from existing facilities that may be directly salvaged or reused without substantial alteration or reprocessing, and (4) devel oped guidelines that project managers can use to organize a construction project recycling program.

\section{Approach}

This research project was based primarily on a review of literature, including Army regulations and policies, popular and technical journals, reports, solid waste industry reports, and interviews. The complexity of this type of project, as well as the growing awareness of the significance of the $C \& D$ waste problem warranted a comprehensive and systematic study of the entire spectrum of issues concerning recycling of construction and demolition debris on military installations.

This report presents an innovative approach to construction and demolition waste management. The current level of construction and demolition in the Army, and also any programs, regulations, or policies that may affect the level of construction

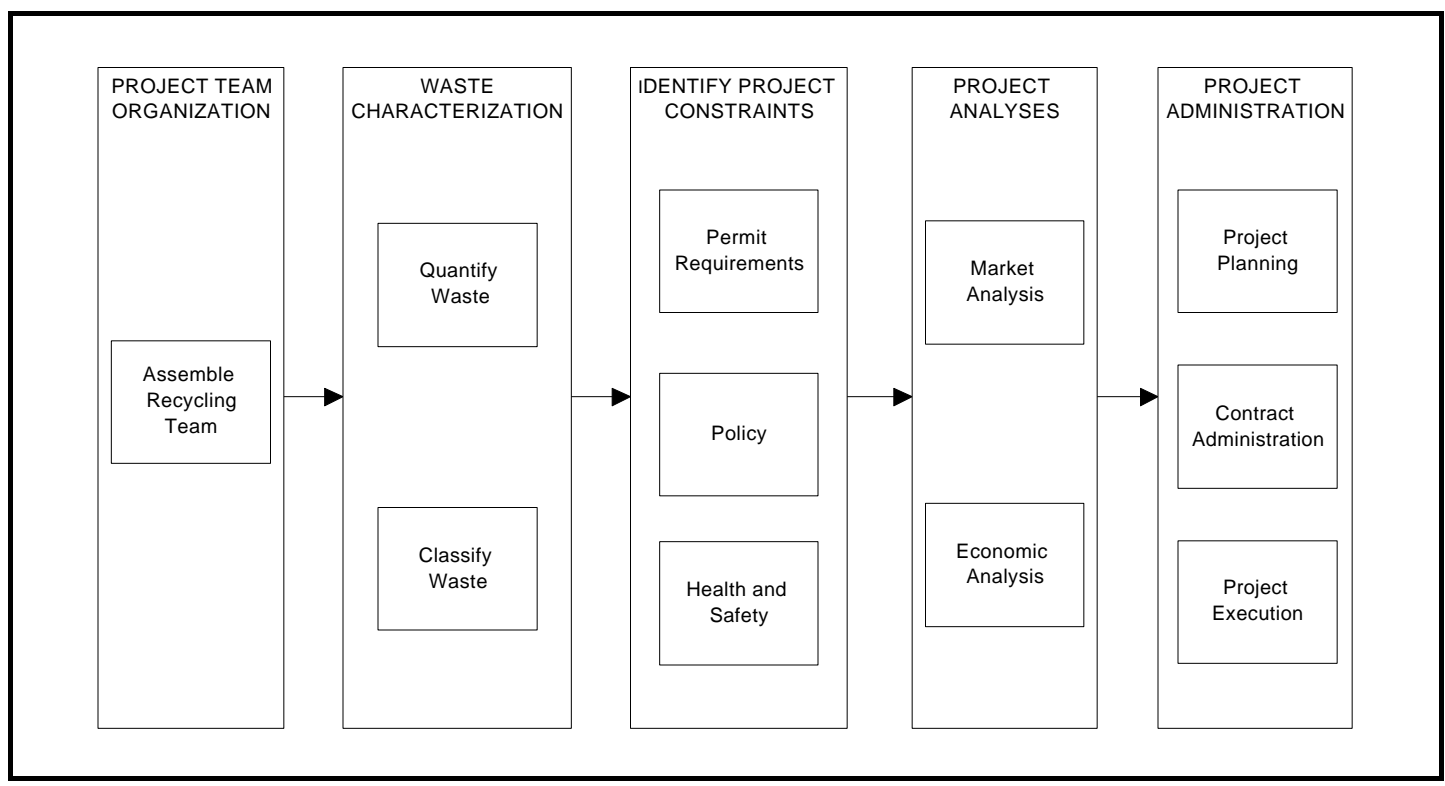

Figure 2. Development of a recycling plan. 
in the future are addressed and provide the justification for increasing the level of recycling $C \& D$ waste on military installations. 


\section{Scope}

The organization of the research was based around the eventual development of guidelines for developing a $C \& D$ waste recycling project on the construction site. Thevarious aspects of construction recycling projects to beaddressed by this project include:

- quantifying the waste

- classifying the material, including salvage and recycling potential

- developing a Recycling Action Plan, including: (Figure 2)

- identification of possible markets

- planning site storage and handling

- identification of possible hazardous waste and permitting requirements.

- assessing recyclability of material class, including:

- existing markets

- potential markets

- constraints, including:

- institutional

- scheduling

- economic

- environmental

- safety and health.

Included is a review and analysis of existing data on the quantity of waste per building structural type, leading to the devel opment of a baseline waste generation rate for each of the following categories per building structural type:

- asphalt

- building equipment

- concrete

- glass
- gypsum/plaster

- masonry

- packaging materials

- soil.
- steel

- other metals

- wood

Since increased recycling on the part of the contractor is new and may not have perceived benefits for the contractor, the project manager must also consider how to best structure the project (contract, etc.) to maximize recycling. Construction contracting issues that must be addressed are: (1) contract specifications, and (2) operation supervision.

For most Army facilities, an extensive $C \& D$ wasterecycling operation will entail an investment of both time and financing capital. The project will investigate the five 
factors that will affect the financial and methodological feasibility of the recycling project:

- material costs

- energy costs

- capital investment costs

- expected condition of the recycled material

- scheduling.

\section{Mode of Technology Transfer}

It is anticipated that the information from this study will be used to draft a Handbook for Managing Construction and Demolition Wastes for use by engineers and managers involved with construction and demolition activities on Army installations. This handbook could be published as a Technical Instructions (TI) document. Other information in this report may be used to hel $p$ formulate new or to revise existing Army/Corps Policy regarding $C \& D$ waste issues. Note that, as this report was going to print, funding was received to initiate the above referenced Handbook for Managing Demolition Wastes.

\section{Metric Conversion Factors}

The foll owing metric conversion factors are provided for standard units of measure used throughout this report:

$\begin{aligned} 1 \mathrm{in.} & =25.4 \mathrm{~mm} \\ 1 \mathrm{ft} & =0.305 \mathrm{~m} \\ 1 \mathrm{sq} \mathrm{ft} & =0.093 \mathrm{~m}^{2} \\ 1 \mathrm{cu} \mathrm{ft} & =0.028 \mathrm{~m}^{3} \\ 1 \mathrm{cu} \mathrm{yd} & =0.7645 \mathrm{~m}^{3} \\ 1 \mathrm{lb} & =0.453 \mathrm{~kg} \\ 1 \mathrm{gal} & =3.78 \mathrm{~L} \\ 1 \mathrm{psi} & =6.89 \mathrm{kPa} \\ 1 \mathrm{ton} & =0.907 \text { metric ton }\end{aligned}$




\section{Construction and Demolition Waste}

Waste is produced in different types and quantities throughout the life-cycle of a building with the bulk of the waste (not including wastes generated by building occupants as part of operations) being produced during the construction and demolition phases. Figure 3 schematically represents thelife-cycle of a building and indicates the use of materials and the waste generated during this life-cycle. The challenge is to reduce or eliminate the wastes that follow the various paths leading to the landfill. The overall problem exists due to factors such as the use of materials and processes that create disposal problems, the use of materials that have no potential for future reuse or recyding, the use of inefficient materials, and the use of designs and details that result in excessive waste when executed at the job site. This report focuses on ways to reduce the burden on landfills by focusing on the various points of $C \& D$ waste generation and the paths that lead to the landfill.

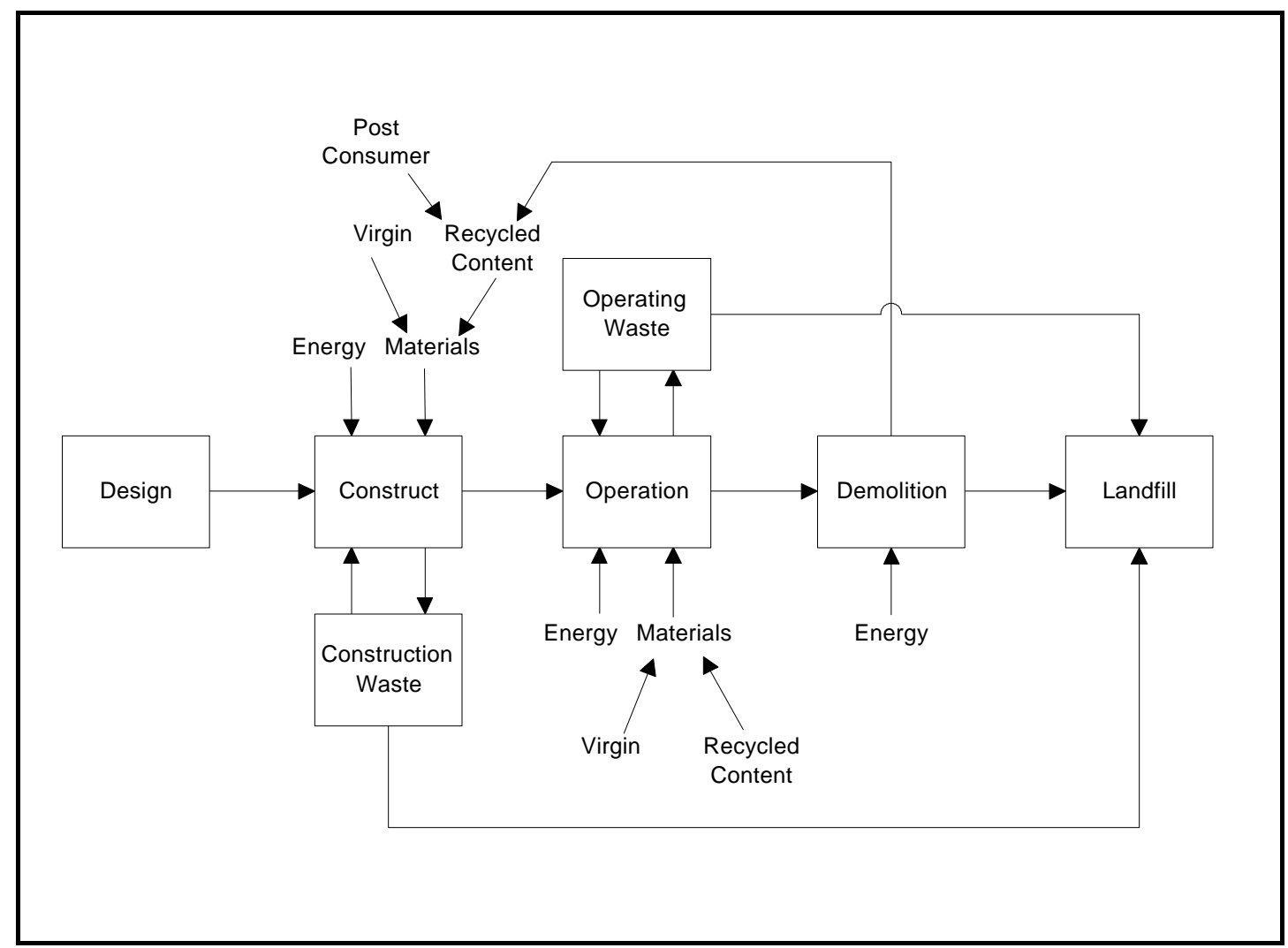

Figure 3. Use of materials and $C \& D$ waste generation in the life cycle of buildings. 


\section{Definitions}

The terms "construction" and "demolition" are used to describe a wide variety of activities involving the fabrication, installation, renovation, and removal of Army facilities. TheU.S. Environmental Protection Agency (USEPA) defines C\&D waste as: "The waste building materials, packaging, and rubble resulting from construction, remodeling, repair, and demolition operations on pavements, houses, commercial buildings, and other structures." (40 CFR 243.101).

Most contractors consider the waste produced during construction or demolition as a homogenous by-product of the construction process. All cut-off material, packaging, and spent containers are placed into the same refuse container even though the nature of the waste may vary across each type of activity. Major renovation projects, for example, create significantly more amounts of $C \& D$ waste than new construction projects, particularly if the renovation involves substantial demolition of the existing structures. A survey of the DA activities that produce $C \& D$ waste includes:

$\begin{array}{llll}\text { - } \text { road work } & \text { - } & \text { site work } & \text { - excavation } \\ \text { - demolition } & \text { - } & \text { construction } & \text { - }\end{array}$

Table 1 describes the most commonly found components of each class of activity.

\section{Waste Characterization}

There are two components to the characterization of construction and demolition waste: (1) composition and (2) quantity. The composition of the waste is defined by the type of included constituent components. The quantity of $C \& D$ waste is based either on the volume or weight of the debris depending on the requirement

Table 1Common components of construction and demolition activities.

\begin{tabular}{|l|l|}
\hline Road Work & Asphalt; Concrete; Soil; Reinforcing Metal. \\
\hline Site work & $\begin{array}{l}\text { Soil; wood, including trees and brush; organic matter; sand; stone; concrete; } \\
\text { pipe. }\end{array}$ \\
\hline Demolition & $\begin{array}{l}\text { Mixed rubble, including wood, concrete, masonry, and steel; fixtures; } \\
\text { mechanical equipment, etc. }\end{array}$ \\
\hline Construction & $\begin{array}{l}\text { Scrap wood; roofing; wall board; insulation; flooring; ducts; pipe; packaging; } \\
\text { fasteners; concrete; steel. }\end{array}$ \\
\hline Renovation & $\begin{array}{l}\text { Scrap wood; roofing; wall board; insulation; flooring; ducts; pipe; fixtures; } \\
\text { mechanical equipment; packaging; fasteners; concrete; steel. }\end{array}$ \\
\hline
\end{tabular}


of the hauler/processor.

One objective of this report is to add two additional components within this description: recyclability and salvageability. The recyclability of a material is defined as its potential for reuse after some form of substantial processing. Processing may take the form of reduction of the debris to its constituent materials. The salvageability of materials is defined as the potential to reuse them in their current state. Chapter 3 discusses the recycling issues in building materials and Chapter 4 studies salvaged building materials and systems.

\section{Composition of Waste}

Construction waste does not typically have the same characteristics as demolition waste. Building material inputs are principally needed during construction and operation. A builder will typically order excess sizes or quantities of materials to ensure that there will be enough materials on hand to construct the building. One economic objective in the construction of a building is to produce a facility in the most cost-effective manner possible. For a contractor, this may involve procuring standardized building products to take advantage of the economies of scale. A contractor purchases rolls of insulation, sheets of gypsum wall board, etc., rather than single pieces. To accommodate the specific situation of a particular system or configuration, these standard units must be trimmed to fit.

By weight or by volume, wood, drywall and cardboard combined make up between 60 and 80 percent of jobsite waste in construction projects (Yost and Lund 1997) Even prefabricated assemblies, such as doors and windows, which are packaged in large quantities of cardboard, metal or plastic strapping, and wood tend to produce a significant amount of wast at construction sites. Concrete is also one of the largest and most visible components of construction waste. In new construction, partial truckloads of concrete have long been a disposal problem. To avoid creating waste, ready mix plants have come up with many innovative solutions. Unused portions are returned to produce concrete retaining wall blocks or highway dividers, or the unset concrete is washed to recover the coarse aggregate for reuse.

Construction waste will also vary according to the type of project. For example, the construction of an interior partition will generally involve discarding lumber cutoffs, scrap pieces of gypsum wall board, and excess insulation. The framing of wood buildings typically produces, by percent to square foot of area, the most waste. However, an efficient design and framing plan cannot only reduce the required amount of material but can also decrease disposal costs by keeping excess $2 x$ wood cutoffs to a minimum. 
Demolition produces a significantly different wastethan construction or renovation. Demolition debris is more likely to contribute materials contaminated by undesirable components and/or potentially toxic substances such as lead paints, stains, and adhesives. In some cases, the physical and chemical makeup of the individual constituent material has been changed by the use of finishes or maintenance techniques. Wood flooring, for instance, when finished with a sealer, such as varnish, has an altered chemical composition.

In terms of solid waste management, the biggest problem with demolition debris is that the various types of debris are mixed together during the course of the demolition. Even with careful manual disassembly of the structure (deconstruction), different types of materials mixed together arestill possible. For example, the removal of exterior walls in a load-bearing masonry system will result in a combination of masonry units, such as concreteblock or brick, mild steel reinforcing metal, metal ties, and grout. In this case, further processing beyond typical deconstruction practices would be required to separate all of the dissimilar materials.

As mentioned above, the composition of $C \& D$ waste varies according to the type of project and the method of construction and demolition. In terms of the individual components, there are sixteen categories of materials that make up C\&D waste in general. Table 2 lists these categories and their sources. Each class of materials consists of several different types of materials. This information is a survey of all individual components that may or may not be found in a building (Appendix A). Several of these dasses of materials, such as concrete, masonry, and ceramics are considered inert by solid waste authorities-because they will not degrade by bacterial activity once landfilled. There are, however, many components of $C \& D$ waste that are not inert in nature and, therefore, are putrescible. Wood is the best example of a material the will putrefy under the right conditions in a landfill. Therearealso several types of materials that can beconsidered chemically-reactive, such as paint, paint thinner, etc., and must be handled in a special manner.

\section{Quantifying Waste}

The amount of $C \& D$ waste produced in the United States depends on several variables. Donovan (1991) suggests that the amount of C\&D waste generated at the national level depends on: 
- the extent of growth and overall economic development that drives the level of construction, renovation, and demolition

- $\quad$ periodic special projects, such as urban renewal, road construction and bridge repair, and unplanned events, such as natural disasters

- $\quad$ availability and cost of hauling and disposal options

- local, State and Federal regulations concerning separation, reuse, and recycling of $C \& D$ waste

- $\quad$ availability of recycling facilities and the extent of end-use markets.

There are few comprehensive estimates of $C \& D$ waste generation rates at the national level. It has been either historically aggregated into the municipal solid waste data, or not accounted for since there are so many nonregulated disposal options. Brickner (1997) estimates that the quantity of $C \& D$ debris generated is over 100 million tons per year. This equates to almost 35 to 40 percent of the total amount of municipal solid waste.

Table 2C\&D waste material categories and sources.

\begin{tabular}{|c|c|c|}
\hline Waste Material & Demolition Source & Construction Source \\
\hline Asphalt & $\begin{array}{l}\text { Roads, bridges, parking lots, roofing materials, flooring } \\
\text { materials }\end{array}$ & Same \\
\hline Brick & $\begin{array}{l}\text { Masonry building equipment white goods, appliances } \\
\text { installed equipment }\end{array}$ & Same \\
\hline Ceramics/clay & Plumbing fixtures, tile & Same \\
\hline Concrete & $\begin{array}{l}\text { Foundation, reinforced concrete frame, sidewalks, } \\
\text { parking lots, driveways }\end{array}$ & Same \\
\hline Contaminants & $\begin{array}{l}\text { Lead-based paint, asbestos insulation, fiberglass, fuel } \\
\text { tanks }\end{array}$ & Paints, finishes \\
\hline Fiber-based & Ceiling systems materials, insulation & Same \\
\hline Glass & Windows, doors & $\mathrm{N} / \mathrm{A}$ \\
\hline Gypsum/plaster & Wall board, interior partitions & Same \\
\hline Metals, ferrous & $\begin{array}{l}\text { Structural steel, pipes roofing, flashing, iron, stainless } \\
\text { steel }\end{array}$ & Same \\
\hline Metals, nonferrous & Aluminum, copper, brass, lead & Same lead \\
\hline Paper/cardboard & $\mathrm{N} / \mathrm{A}$ & $\begin{array}{l}\text { Corrugated cardboard, } \\
\text { packaging }\end{array}$ \\
\hline Plastics & Vinyl siding, doors, windows, signage, plumbing & Same \\
\hline Soil & Site clearance & Same, packaging \\
\hline Wood, treated & Plywood: pressure- or creosote-treated, laminates & Same \\
\hline Wood, untreated & Framing, scraps, stumps, tops, limbs & Same \\
\hline
\end{tabular}


At the local level, the difficulty in quantifying the amount of waste being landfilled is due to the difficulty of measuring specific quantity of the waste. $C \& D$ debris is handled by a myriad of individual contractors, wastehaulers, and landfill operators. The amount of materials handled by each one of these handlers would have to be measured to accurately determine generation rates. Many studies have found that landfill operators' either keep no records, or keep records that are inadequate to determine waste generation rates of the original producer. Another difficulty in quantifying the waste is its highly variable and heterogenous nature. The amount of waste produced by one contractor may differ significantly that produced by another, due primarily to the level of expertise or training of employees. Finally, estimating C\&D waste by State may not be very accurate because many States allow inter-state disposal of this waste.

There have been several attempts to quantify $C \& D$ waste according to generalizable variables, such as per capita. The Solid Waste Association of North America (SWANA) suggests a method to determinethe $C \& D$ wastegeneration data for a community, which includes the following steps:

1. Contact the State regulatory officials for a list of licensed sanitary landfills and/or C\&D waste landfills in the study area.

2. I dentify the types of businesses and industries, by Standard Industrial Code $(\mathrm{SIC})$, that have the potential to generate $C \& D$ waste.

3. Determine the specific materials that are to be included in the $C \& D$ waste stream estimate (based on type and quantity of materials estimated to be generated).

4. Interview major generators of $C \& D$ waste (including general buildings contractors, demolition contractors, land clearing contractors, etc.) to obtain estimates of C\&D waste materials generated, recycled, and disposed.

5. Interview local landfill operators and inspect weight records, if available.

6. Interview State and local Department of Transportation (DOT) officials for planned road and bridge related activities.

7. Interview local municipal planners to discuss any major upcoming construction or demolition quantities.

8. Develop estimates for each of the "major components" of the C\&D waste stream (SWANA 1993).

Another method to determine municipal waste generation rates for specific classes of materials was suggested by Y ost and Halstead (1996). Y ost and Halstead related the dollar value of construction collected by the Census Bureau and per square footage of building waste generation rates, with the square footage of construction 
(obtained from building permit records) of a large geographic study area, to generate an estimate of gypsum board waste.

The prediction of waste generation quantities for a single building project has only had a limited amount of study. This type of data, however would be useful to both solid waste authorities as well as construction project administrators, since it would allow them to accurately develop a recycling project plan. It would also allow the recycling manager of a $C \& D$ project to performaccurateeconomicanalysis, market identification, and plan for storage/handling.
Table 3Volume-weight conversions.

\begin{tabular}{|l|l|}
\hline Material & Conversion Rate \\
\hline Wood & $\begin{array}{l}300 \mathrm{lb} / \mathrm{cu} \text { yd. } \\
6.7 \mathrm{cu} \text { yd./ton }\end{array}$ \\
\hline Cardboard & $30-100 \mathrm{lb} / \mathrm{cu}$ yd. \\
& $20-50 \mathrm{cu}$ yd./ton \\
\hline Drywall & $400 \mathrm{lb} / \mathrm{cu}$ yd. \\
& $5 \mathrm{cu}$ yd./ton \\
\hline Rubble & $1400 \mathrm{lb} / \mathrm{cu}$ yd \\
& $1.4 \mathrm{cu}$ yd./ton \\
\hline Mixed waste & $350 \mathrm{lb} / \mathrm{cu}$ yd. \\
& $5.7 \mathrm{cu}$ yd./ton \\
\hline \multicolumn{2}{|l|}{ *Source: Yost and Lund (1997). } \\
\hline
\end{tabular}

Accurately predictingthequantity of individual wastematerials froma construction or demolition project is, however, problematic. For some materials, such as concrete, the project team may be able to reasonably determine the total volume of reinforced concrete that is in a specific building, based on a survey of the total volume of individual components of the concreteframe, i.e., the columns, floor slabs and foundation. It is not certain, however, if the predicted amount is the total amount that can be sent to a recycling facility. Factors such as the method of demolition and the method of collection will greatly influence the amount of material gathered at a site. For other materials such as steel, there are many more factors that go into the amount of material that is used in the fabrication of a building.

Accurately measuring the building and its individual components is also problematic. Some materials are not readily available for measurement, or are difficult to measure, particularly if the building is in use. The ceiling, walls, or floors will have to be opened to identify types and amount of materials. In most cases, this should be a minor difficulty since the building or part of the building in question has already been identified for demolition. If the building is not to be systematically deconstructed, it may be too difficult for the project manager to approximate the quantities by inspection. In these cases, the best source of information may be the original blueprints or "as-built" drawings for the building.

Once the quantity of each material class has been estimated, the next step is to transform this information into either weight or volume estimates. Table 3 lists volume-weight conversions for wood, cardboard, drywall, and mixed waste. There 
are some references available that may assist the project team in specifically determining the quantity of each of the seventeen categories of materials. The American Society of Civil Engineers' Minimum Design Loads for Buildings and Other Structures (ASCE 7- 95), for example, lists the minimum design loads, or dead loads, for different building materials and systems. Army Technical Manual 5-8091, Structural Design Criteria for Loads, also lists the design dead loads for various materials and systems. Another source for dead loads and system weights for various building assemblies is Means Assemblies Cost Data (1994).

For instance, the weight per square foot of a plaster and lath partition wall is, according to the ASCE 7- 95, $8 \mathrm{lb} / \mathrm{sq} \mathrm{ft}$ (ASCE 1995). Once the total wall area has been calculated, this figure can be multiplied by this weight per square foot to obtain the total weight of the plaster and lath in the building. For example, a wall area of 3000 square feet would calcuate as follows:

$3000 \mathrm{sq} \mathrm{ft} \times 8 \mathrm{lb} / \mathrm{sq} \mathrm{ft} \times 2000 \mathrm{lb} /$ ton $=12$ tons of plaster and lath

Typical densities for construction material and some assemblies are listed in Table 4. Density for all materials and subassemblies (e.g., toilets, ductwork, etc.) are not available at this point. The recyding project manager will have to make estimates based on experience or physical measurement. This information can then be used to quantify the various categories of materials.

\section{Current Waste Stream}

Every stage in the building life cycle involves the consumption of materials (F igure 3). Because materials are used in both the physical aspect of the building as well as the processes involved in the fabrication, operation, and maintenance of the building, waste is produced.

At each stage during the facility life cycle, materials are discarded as either waste products or obsolete assemblies. Approximately 97 percent of building materials (exclusive of concreteand brick) are not being recycled at the end of their usefulness (Gordon and Huddart 1997). Some of the factors that influence the disposition of un-needed material as waste include the high price of labor needed to reuse the materials, the low relative cost of new or virgin materials, resistance by regulatory authorities, or the impracticability (financially or otherwise) of reuse. 
Table 4Typical densities for construction material.

\begin{tabular}{|c|c|}
\hline Materials \& Description & Density (lb per cu ft) \\
\hline Gypsum or plaster board & 50 \\
\hline Plywood & 34 \\
\hline Sheathing, fiberboard & $18-25$ \\
\hline Particleboard & 40 \\
\hline $\begin{array}{l}\text { Blanket and Batt Insulation } \\
\text { mineral wool, fibrous form }\end{array}$ & $0.3-2.0$ \\
\hline $\begin{array}{c}\text { Boards and Slabs Insulation } \\
\text { Cellular glass }\end{array}$ & 8.5 \\
\hline Glass fiber & $4-9$ \\
\hline Expanded rubber (rigid) & 4.5 \\
\hline $\begin{array}{l}\text { Expanded polyurethane (R-11 } \\
\text { blown) }\end{array}$ & 1.5 \\
\hline Acoustical tile & $18-23$ \\
\hline Cement mortar & 116 \\
\hline Sand \& gravel or stone aggregate & 140 \\
\hline Stucco & 116 \\
\hline Brick, common & 120 \\
\hline Brick, face & 130 \\
\hline Granite, marble & $150-175$ \\
\hline Aluminum & 171 \\
\hline Brass & $524-542$ \\
\hline Copper & $550-555$ \\
\hline Iron, gray cast & $438-445$ \\
\hline Iron, pure & $474-493$ \\
\hline Lead & 704 \\
\hline Steel & 490 \\
\hline Cement plaster, sand aggregate & 116 \\
\hline Gypsum plaster & 45 \\
\hline 1-ply membrane roofing & 83 \\
\hline Asphalt roll roofing & 70 \\
\hline Asphalt shingles & 70 \\
\hline Built-up roofing & 70 \\
\hline \multicolumn{2}{|l|}{ * Source: Hoke (1988). } \\
\hline
\end{tabular}

For most contractors, waste management is not a critical issue in the planning and operation of a building project. Construction and demolition wastes area necessary by-product of the delivery of a facility. Traditionally, the only consideration given to waste issues is the identification of the most cost-effective disposal option and its implementation. This has not, though, excluded recycling C\&D waste in the past since, when it is cost-effective and legally acceptable to do so, many contractors recycle waste materials such as concrete and metal. 
The sol id waste policy in theArmy is based on the concept of I ntegrated Solid Waste Management (ISWM), which is designed to minimize the initial input to the waste stream through waste reduction, reuse, and recycling (AR 420-49). To add a recycling component in project planning, the project manager must know how $C \& D$ waste is handled in the current waste stream.

The typical flow of materials for small to medium size projects begins with a hauler dropping off a roll-off or other container at the project site and the contractors discarding waste in the container. Once notified that the container is full, or by prearrangement, the hauler will pick it up and dispose of it in either a sanitary or $C \& D$ landfill. The hauler may charge by volume (typically, the capacity of the container) for relatively low-density materials such as wood waste, and by weight for dense materials such as metal. The amount charged, commonly referred to as a tipping fee, is determined by the nature of the waste, local applicable regulations, or by the final disposal technique. The charges for scrap metal, for example, are usual ly computed by weight since most metal smelters will purchasetheir feedstock from these scrap dealers.

Disposal of C\&D waste in a landfill is not the only option available to contractors or solid wastemanagers. Donovan (1992) describes thecurrently availabledisposal options for construction materials:

- $\quad$ permitted disposal, either on-site or off-site, by burying or burning the waste

- unpermitted disposal, either on-site or off-site, by burying or burning

- re-use of the waste by salvaging usable materials or assemblies

- recycling the waste into another, usable form.

$C \& D$ waste haulers are typically the same companies that haul to re-processors or landfill sites. Most haulers are either independently contracted by the contractor or are affiliated with a current waste processor or landfill operator. Although in most States a MSW hauler must be licensed, the same may not be true for every State's C\&D waste haulers. Many State health organizations believe that the mostly inert C\&D waste does not pose the same health risks to operators as does MSW. This situation may change due to the increasing awareness of the environmental impacts of demolition debris landfills (demofills).

According toSWANA (1993) thereare approximately $1800 C \& D$ landfill sites in the United States. The type of materials that these demofills accept varies by State, even by community, but primarily they accept inert materials such as concrete, asphalt, and masonry. Many demofills also accept wood, soil, gypsum, and plastics, but in the face of increasing evidence of the unacceptable liquid leaching from older 
demofills, these materials will more likely be directed to a MSW landfill. The USEPA's recently enacted Federal municipal landfill regulations (40 CFR 258) restrict the disposal of $C \& D$ waste in new MSW Iandfills to increase their service lives. In anticipation of stricter Federal and State guidelines for demofills, some waste management firms are contemplating using MSW landfills features in their demofills, such as impermeable liners, to prevent run-off or leaching. These improvements will, in effect, increase the waste generators' disposal costs.

In the past, one option for the disposal of construction and demolition debris was to burn it on or off site to reduce its volume. This technique reduced the overall amount of physical mass to be disposed, but contributed to the release of gases and particulatematter intotheatmosphere. Unregulated or widespread refuse burning is generally accepted to have a negative effect on air quality. It also creates a hazardous physical condition in the case of large fires. In many cases, some debris can be incinerated for energy recovery. In most States a permit is required to burn any form of debris. Therefore, the availability of this option depends on local authority. Besides the loss of material resources, the increasing stringency of air quality regulation has made this option less desirable. Regulated or authorized burning of $C \& D$ waste still occurs in some areas, but only in special cases such as the clean up after natural disasters. Due to the Army's policy to recover as many resources as possible from the solid waste stream, incineration is an unlikely disposal option for military solid waste managers (AR 420-49).

Therehas, of course, al ways been some form of unpermitted disposal of C\&D debris. As mentioned previously, the economics of construction and demolition projects encourage contractors to find the lowest cost of disposal. In the face of expensive tipping fees, many contractors have opted for alternatives, including burying the waste on-site or in an un-permitted site. For some inert materials such as concrete and masonry, many States allow the contractor to directly use the waste on site as back-fill for foundation work. Again, in the face of increasing evidence of health problems and negative environmental impacts of burying or burning this waste, disposal according to methods dictated by State and local waste authorities is the best method.

\section{Regulatory Environment}

The Base Closure and Realignment Act of 1988 and the Defense Base Closure and Realignment Act of 1990 require the DOD, or in specific cases other Federal agencies, to comply with a variety of laws and associated regulations that effect 
Federal real property disposal at most BRAC installations. Pertinent environmental legal provisions with jurisdiction at BRAC installations include:

- Comprehensive Environmental Response, Compensation, and Liability Act [CERCLA] Section 120, which establishes a framework for responding to releases of hazardous substances, pollutants, or contaminants in all media at all installations, as well as specific requirements for property transfer at BRAC installations

- Executive Order 12580 and the statutory provisions of the Defense Environmental Restoration Program [DERP], of which the Installation Restoration Program [IRP] is a sub-component

- National Environmental Policy Act [NEPA], which governs the Federal evaluation of the environmental consequences of disposal (i.e., selling or transferring) of surplus F ederal property to the public or private sector

- Resource Conservation and Recovery Act [RCRA] requirements under Subtitles C, I, and D, which govern most environmental mission/operationalrelated and cl osure-related compliance activities. These compliancelaws may also be applicable or relevant and appropriate requirements for selecting and implementing remedial actions under CERCLA.

All BRAC installations are subject to RCRA, particularly because most generate, transport, store, treat, or have disposed of hazardous waste. Subtitle D of the RCRA regulates the proper disposal of solid waste, which almost exclusively refers to nonhazardous solid waste. Subtitle D covers all wastes not regulated by Subtitle C, which regulates hazardous waste and Subtitle I, which regulates petrol eum products and other hazardous substances as defined in CERCLA Section 101 (14). Certain hazardous wastes that are excluded from Subtitle C, such as household hazardous waste and hazardous wastes generated by small quantity generators, are also covered under Subtitle D. Section 100 (27) of the Act defines solid waste as:

- Garbage, e.g., milk cartons and coffee grounds

- $\quad$ Refuse, e.g., metal scrap, wall board and empty containers

- $\quad$ Sludge from a waste treatment plant, water supply treatment plant, or pollution control facility

- $\quad$ Other discarded material, including semisolid, liquid, or contained gaseous material resulting from industrial, commercial, mining, agricultural, and community activities, e.g., boiler slag or fly ash. 
Most construction and demolition waste, therefore, is also covered by RCRA, Subtitle D. Sincethere have been very few F ederal studies of C\&D waste, thereare few Federal regulations pertaining strictly to C\&D waste. The RCRA, an amendment of the Solid Waste Disposal Act (SWDA) of 1976, 42 U.S.C. 6901 et seq., addresses how to safely dispose of the huge bol ume of municipal and industrial soid wastegenerated nationwide. The RCRA permits states and local governments to enact their own waste management programs, which the state would be responsible for enforcing. At the State level, most $C \& D$ regulations pertain to landfill issues such as excluding certain types of materials.

The recently enacted Federal municipal landfill regulations do not affect the disposal of C\&D waste unless it is disposed of in a MSW Iandfill. Effective October 1993, these regulations place stringent siting, design, and operating requirements on the owners/operators of MSW landfills. Stricter regulations will also limit the type of material that can be disposed in a demofill. The Solid Waste Association of North America found that 32 States exclude some C\&D materials from demofills (SWANA 1993). According toSWANA, thereare eight States that requireoperators to meet the same State regulations as MSW sanitary landfills to prevent toxic leachate from leaking from the demofills. Other States, such as New J ersey, use new solid wasterules that encouragetherecycling of $C \& D$ waste by strictly limiting the disposal of $C \& D$ debris. In response to these stricter disposal guidelines, information in this study will provide the basis for solid waste managers to identify and possibly avoid materials that could limit the number of disposal/recycling options.

Recovery of valuable resources is not the only incentive to the $D A$ to recycle $C \& D$ waste. In many cases, the costs of conventional disposal of C\&D waste (i.e., landfilling) have increased to the point where recovery and reuse of the waste is economically feasible. The increase in the tipping fees charged by landfills is being caused by both the overall decrease in the amount of landfill space, as well as the increasing costs of managing landfills.

Another incentive to increase the amount of recycling of $C \& D$ waste is the effort on the behalf of Federal agencies, such as the USEPA and General Services Agency (GSA), to increase the procurement of recycled content products. Until just recently, building materials have not been emphasized in these procurement guidelines. Increased recycling of $C \& D$ waste will "close the loop" of material procurement and reuse by increasing the amount of materials available for procurement. 


\section{Recycling Issues in Building Materials}

\section{Definition}

Reclamation of material from the waste stream is not completely considered recycling in and of itself. Recycling, on the other hand, is the reprocessing of a reclaimed material and converting it into a new material or use. Army Technical Manual 5-634, Solid Waste Management, considers recyclable materials as those that have been or would be discarded and can be reused after undergoing sometype of physical or chemical reprocessing.

Recycling construction and demolition debris is hardly a new concept for the construction industry. Concrete and paving materials have been reused as fill material or roadbed for many years. In fact, the form of concrete used by the Romans included "recycled" aggregate from older stone structures. In many areas of the country, particularly in the Northeast where landfill space is at a premium, the recycling of some $C \& D$ debris is becoming more commonplace.

There are several reasons besides the cost of disposal for the increased interest in recyding $C \& D$ waste. The decreasing availability of a high-quality resource base for the manufacture of building materials is an important consideration. In many cases, the sources for "virgin" materials are great distances from installations/building projects and transportation costs warrant contractors to look for a local replacement. For example, aggregate from demolition rubble can be an abundant and prevalent local source of road base and fill. An additional benefit to the use of demolition aggregate is that the virgin quarried aggregate will not have to be used in such low value applications such as backfill. In this case, a low cost but equivalent recycled product such as demolition aggregate is an acceptable substitute. There are other products such as recycled gypsum board and lumber that are being used in new construction projects.

The increasing cost of materials manufactured with virgin materials is also an incentive for recycling materials. Recycled asphalt paving (RAP) is an acceptable replacement for new asphalt in road base and secondary pavement construction, such as driveways and parking lots. The cost savings comes from the reduction of transportation costs for the virgin aggregate, and reduction of asphalt cement 
requirements. In a large paving project, the savings to the owner can be significant. The estimated potential savings can range from 20 to 30 percent (Brown and Basset 1988).

Steel has also been extensively recycled in the past. Steel and other metals generally do not lose their physical properties after resmelting. The high price steel mills are paying for scrap, as well its relative ease of separation from $C \& D$ debris (by magnet), have made it an attractive material for scrap dealers. The Army maximizes the amount of recycling of ferrous and nonferrous scrap through the DOD's Scrap Recycling Program and the Defense Property Disposal Office (DPDO).

From a recycling standpoint, the more material reused, the fewer resources are consumed. Within recycling operations, the amount of resources and capital equipment involved can be placed in a hierarchy:

- $\quad$ recycling on site (to reduce transport and handling)

- recycling locally off-site by separation and minimal processing

- recyding at a central station

- $\quad$ recycling at a long range plant (200 miles plus).

In a recycling operation, it is useful to classify the debris for recycling according by this hierarchy. For example, in an office space renovation, doors and door jambs could be carefully removed, stored on-site, reconditioned as necessary, and then replaced in their new locations. Recycling is taking place on-site with minimal processing. Classifying debris by its recyclability such as this is useful because of justification, and program targets.

\section{Recycling Initiatives in DOD, and Nationwide}

There is some concern in the DA for the amount of solid waste produced on installations and the environmental effects of its disposal. Several programs now exist to reduce the overall amount of waste produced on military installations and to encourage recycling. Definitions, policies, and direction indicated in this report are based on information derived from the following applicable solid waste regulations:

- Executive Order 13101, Greening theGovernment Through WastePrevention, Reycling, and Federal Acquisition 
- DOD Directive 4165.60, Solid Waste Management - Collection, Disposal, Resource Recovery and Recycling Program

- Army Regulation 200-1, Environmental Quality: Environmental Protection and Enhancement

- Army Regulation 420-49, Utility Services

- Army Technical Manual 5-634, Solid Waste Management

- Army PAM 420-47, Solid WasteManagement

- TN 420-47-02, Installation Recycling Guide.

The Executive Order Number 13101, Greening the Government Through Waste Prevention, Recyding, and Federal Acquisition, was signed on September 14, 1998. This new Executive Order strengthens and expands the requirements of EO 12873 (now rescinded) for Federal agencies to reduce generation of solid waste, increase recycling, and procure environmentally-preferable products. For recycling and waste prevention, each agency is required to establish a goal for recycling or for diversion of solid waste from landfilling or incineration. The current DOD goal by the end of FY2005, is to divert at least 40 percent of the solid waste, which otherwise would have been sent to a landfill or incinerator by reusing, recycling, composting, or otherwise keeping it from entering the solid waste disposal stream; and the cost of these diversions should be less than the cost of landfilling or incinerating the waste.

The Department of Defense (DOD) al ready had a directive, DOD Directive Number 4165.60, which had the objectives to conserve natural resources by:

1. J udicious collecting and disposing of solid waste

2. Reducing the amount of material wasted

3. Recovering and recycling materials and/or energy from solid waste products as an alternativeto burial in landfills, incineration, or environment-menacing dispositions.

\section{Barriers to Recycling}

A significant barrier to increased recycling of $C \& D$ wasteis the variability of supply for recyclers and re-processors. The financial success of any recycling enterprise is 
the dependent on the amount and quality of the supply of feedstock. Most processors will not makea large commitment of capital unless a consistent quantity and composition of waste can be guaranteed. The variability of C\&D waste is due to a number of factors:

- inconsistent composition of $C \& D$ waste

- $\quad$ widely dispersed C\&D activities

- $\quad$ varying C\&D waste management regulations

- $\quad$ range of disposal options, induding prevalence of illegal or unregulated disposal

- $\quad$ varying cost of conventional landfill disposal.

The nature and quality of the waste stock will vary greatly. C\&D waste includes 16 different classes of materials (Table 2), any of which can be expected from typical residential, commercial, or institutional projects. The physical composition of some building materials changes dramatically depending on such factors as theage of the project (in the case of renovation and demolition), availability of resources, and construction/demolition practices.

As mentioned earlier, contamination can also be a significant problem. In most cases, a single container is used for waste collection on a construction site. Commingled waste is difficult to segregate unless the separation is done by hand or by specialized machinery. A few classes of materials, such as chemically treated wood, can alter the characteristics of the waste enough to make it unusable as feedstock for recycled materials. Hazardous materials such as asbestos or leadbased paint can contaminate the waste and make it unusable as feedstock for other materials. If hazardous waste streams are mixed with nonhazardous waste streams, the entire mixture must be treated as hazardous waste.

Location of the project also factors into the feasibility of $C \& D$ recycling since there is not al ways a highly concentrated level of $C \& D$ activity. As a result, thematerials must be transported to accumulate enough material for a centralized recycling operation or to get to a recycling infrastructure. If the economics of recycling depend on the low cost of feedstock, the increased cost of transportation may preclude recycling.

State and local waste management regulations may have a significant impact on the consistency of $C \& D$ waste feedstock availability. Some States consider certain components of $C \& D$ waste exempt from landfill regulations. Many States, for example, allow inert granular material, such as stone aggregate, and wood waste from land clearing to be disposed of on-site as fill. Despite the availability of 
alternative recycling options, it is more cost-effective for contractors to dispose of these materials on-site.

Thevarying nature of solid waster regulations indicates therange of disposal options for $C \& D$ waste. As indicated above, it is still possible in some localities to bury the waste on site or off-site, or incinerate it for fuel. There is also the possibility that a significant portion of the waste is disposed of by un-permitted dumping or burning. Although the amount of this material is difficult to characterize, it probably represents a significant portion of the potential $C \& D$ waste feedstock.

The variability of the cost of conventional landfill disposal also presents a problem in accurately predicting theeconomics of centralized recycling operations. Although in many areas tipping fees at municipal and $C \& D$ landfills areincreasing, they still, at least superficially, represent the lowest cost of disposal to the individual contractor.

Technical information about recycled-content materials is lacking. Many developers, clients and designers are reluctant to use recycled-content materials because of limited testing or code approval.

There are also several project-related barriers to recycling, such as economic and time resource constraints. For example, in most public and private-sector construction and renovation projects, disposal of waste is considered by most contractors as overhead. In most cases, it is not directly calculated in the bid for a project. This means that the contractor will opt for the lowest, first-cost means of disposal. This explains the prevalence of on-site or illegal dumping disposal of the waste. The cost of disposal may not al ways be directly passed on to the client or agency funding the project.

The separation of each material prior to recycling requires increased handling of waste and, subsequently, more work for the contractor. Generally, in preparation for recycling, the waste has to be separated on-site, stored, and transported to a processor. Thecontractor must ther eforeincludeincreased handling and processing fees in the bid. Unless the client has specified certain disposal options, the contractor will opt for the lowest cost solution-landfill disposal.

Once separated, the waste must be stored on site for a period of time until there is a sufficient quantity to transport. Much of the waste, such as wood and gypsum, takes up a great deal of space because it frequently is transported in large pieces. There may not beenough space on a construction site for separate waste containers or access to the debris for haulers. 
The number of persons involved in a project is also a barrier since on large $C \& D$ projects there can be dozens of prime and subcontractors whose efforts to recycle would all need to be coordinated. It also may be necessary to educate those contractors who are not familiar with $C \& D$ waste recycling.

Another important barrier to the recycling of some classes of construction and demolition wastes are governmental regulatory and Army policy that restrict the use of recycled materials. For example, in 1992, SWANA found that only 26 (of 45 responding) States' DOTs allowed the use of recycled asphalt and concrete in pavement and aggregate (SWANA 1993). A Federal Highway Administration (FHWA) report published in March 1996 reached a number of conclusions on asphalt pavement recycling practices. The report concludes that the use of RAP in hot-mix asphalt (HMA) is not uniformly accepted throughout the United States. Only 33 percent of all asphalt pavement removed is recycled into HMA (Federal Highway Report 1996).

The lack of recovery facilities is another barrier to recycling. As described in this section, the amount of capital investment necessary, lack of markets, and the variability of the waste stream has resulted in few large scale, multi-waste processors. The lack of recovery facilities means that, in many cases, contractors have no outlets for $C \& D$ waste even if they want to separate debris for recycling. This is particularly true for small scale $C \& D$ projects such as office remodels or small building construction. Individually, the amount of waste produced by these relatively small projects may not be significant, but in the aggregate of the $C \& D$ activity, it can be significant.

Increasing the amount of recycling of C\&D waste represents a significant change in the way of doing things. It is very easy for contractors to continue with the "status quo." Members of the construction industry assume so much risk that maintaining the status quo, even in the face of increased financial and ethical pressure, means that the contractors and subcontractors at least know the extent of their liability and involvement on a project.

Of several institutional and methodological barriers to recyding construction and demolition waste, the most significant is the potential inability on the part of project managers and solid waste authorities to identify markets for the debris. The limited distribution channels for the debris prevents contractors and solid waste managers from finding appropriate disposal alternatives. The difficulty in accurately characterizing $C \& D$ waste is also a barrier since construction and demolition waste is highly variable in both content and quantity. This variability is due to the nature of the waste, the dispersion of $C \& D$ activities, inconsistent 
waste management regulations, the range of disposal options; and the variance in cost of the disposal options.

The nature of the construction/demolition project contract administration also presents a barrier to increased recycling of $C \& D$ waste by a contractor. In the bidaward contract system used for most Army projects, overhead costs, induding waste disposal, are computed as a fixed percentage of the total contract. I nnovative waste recovery programs typically increase the percent of overhead dedicated to disposal. This forces the contractor to find the lowest first-cost method of disposal of waste. In most areas, this remains the indiscriminate collection of the debris in a single container such as a roll-off box. This heterogenous debris cannot be reclaimed without an intermediate separation step. The additional processing may affect the financial effectiveness of the recycling program.

Finally, an important barrier is the lack of communication between the architects/engineers, contractors, subcontractors, and waste haulers. There are many issues that must be addressed and each party may not understand the roles, responsibilities, and expectations of the other parties. Additionally, if these roles are not explicitly defined before the contract begins, important issues may not be addressed: the waste may not be properly characterization, or the end markets may not be identified.

\section{Benefits of Recycling C\&D Waste}

There are many benefits to the increased recycling of $C \& D$ waste. For the Department of the Army, recycling building materials conserves resources by diverting them from the landfill. F or every recovered pound of concrete re-used in new construction, a corresponding pound of virgin material-based concrete is not consumed. The diversion of bulky and difficult-to-handle $C \& D$ wastefrom the MSW stream will increase the operating life for local landfills and will result in fewer associated environmental impacts such as groundwater contamination.

$C \& D$ waste generators, i.e., contractors, building trades, and clients, can expect lower material and disposal costs in the long term. With the development of new markets for their debris, waste generators may also potentially have new sources of revenue. The cost of salvaging materials such as unique wood millwork and fixtures for reuse by others is generally lower than the price of new comparable materials. Providing that there is a market for these materials, the generator may make a profit on salvaged materials. A benefit for the solid waste industry may be lower operating costs as it finds new markets for the waste materials. 


\section{Managing Construction/Demolition Site Recycling Operations}

Since the perceived benefits of increased $C \& D$ recycling may not be readily apparent to the contractor, the project manager must also consider how the project can be best managed to maximize recycling. The aspects of the construction contract that must be addressed are: (1) contract specifications, (2) material specifications, and (3) recycling operation supervision. Typical contract specifications for a construction project describe the work to be performed and the standards that the contractor must meet. Thespecification that addresses recycling should reflect the additional work the contractor and subcontractors must perform to meet the project's recycling goals. This information may include an explanation of the methods needed to remove and process the materials as well as a description of the final condition this material must be in for it to be marketable. Material specifications include a description of the condition of the material, including weight, size, quantity, etc., that the material is expected to be in at the point of delivery totheend-market. Supervisory issues include defining theexecution of the recycling operation in accordance with the normal construction project objectives. The areas of concern in project supervision include inspection of the operation by a representative of the client or architect/engineer, quality control procedures, and final authorization of the material's condition.

For most Army facilities, an extensive $C \& D$ wasterecycling operation will entail the investment of a large investment of both time and capital. Denison and Ruston (1990) list the factors that should be considered by the solid waste and project managers before commencing with any form of a recycling operation to ensure that the recycling project is both financially and methodologically feasible:

1. The amount of waste generated

2. The composition of the waste

3. The specific materials targeted for recycling and the design of programs intended to recover them

4. The expected effectiveness of participation in the program

5. The type of additional processing required to prepare the recovered materials for marketing

6. The overall costs of recycling handling, collection, and processing

7. Financial and logistical risks and uncertainties associated with the proposal

8. The availability of markets for recovered materials, prevailing prices, price volatility, and the potential effect of market development programs. 
Producing a solid waste recyding operation for Army projects involves nine steps:

1. Assembling an interdisciplinary project team

2. Characterizing the waste

3. Classifying the waste components

4. I dentifying constraints

5. I dentifying end-markets

6. Economic analysis

7. Project planning

8. Contract administration

9. Project operation.

Figure 4 shows the nine steps in this $C \& D$ waste recycling action plan. The first step, assembling a project team, involves identifying the persons with some stake in the success of the recycling operation. Possible members of the team include the construction manager, installation engineer, including the solid waste manager, and a local solid waste authority who will be familiar with local markets and product standards. The next step, characterizing the waste, is critical to managing the operation. The potential success of the project will depend on accurately identifying both the nature of the waste and its quantity. The composition of the demolition waste, for example, will be affected by not only the materials used in the building, but also by their age and location within the building. The quantity of debris will be affected by both the amount of materials and the techniques used to remove the materials or demolish the building. Once the character of the waste is known, the debris may be classified by the amount in which it is recyclable or salvageable.

The next three steps determine both the financial and methodological feasibility of the operation. The project team first determines the permit requirements for the project. This entails defining any potential health and safety issues that will arise in executing the recycling project. One important area is the identification of hazardous or special wastes. The next step is to identify markets for the recycled debris. The local solid waste authority may be helpful in developing a list of endmarkets. They will be aware of appropriate disposal options as well as any new recyding enterprises. The project team determines the market's materials specifications, contract requirements, and prices. Once this information is known, the team performs an economic analysis to check if there is a financial incentive to recycle the waste. The analysis will determine whether the expected revenue from the operation is greater than the added costs of performing the operation. 
The final three steps in the action plan involve planning the project, preparing and administrating the contracts, and finally supervising the operation. 


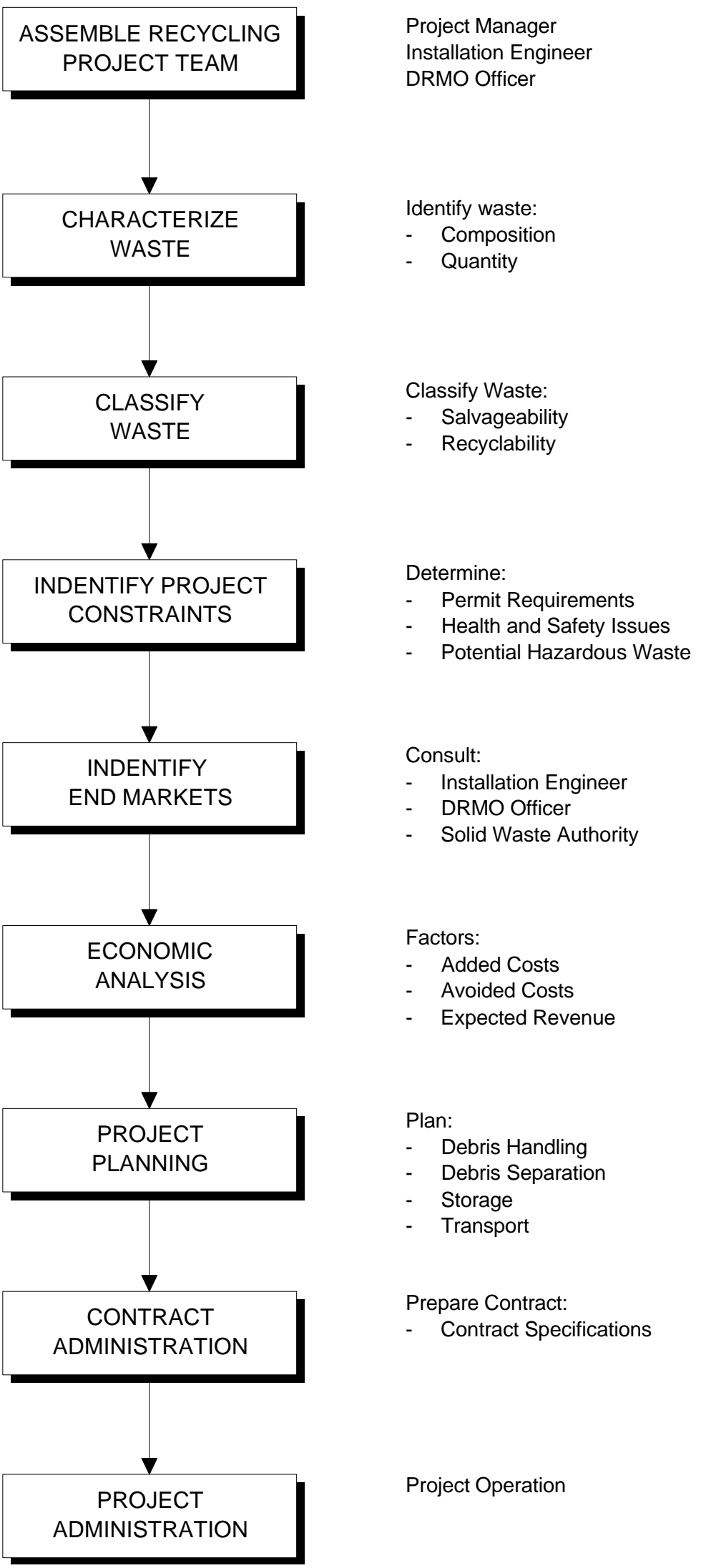

Figure 4. C\&D waste recycling action plan. 


\section{Incentives To Recycle}

There are both direct and indirect incentives to increase the amount of recycling by contractors and waste processors. Direct incentives are those that apply particular strategies to directly achieve recycling goals. Incentives that will directly increase the amount of recycling by DA construction contractors include: banning certain wastedisposal options (such as landfill disposal) and financial incentives, including subsidizing costs of recycling.

The banning of the disposal of all or some of $C \& D$ waste materials from landfills may increase the amount of recycling by contractors. Restricting disposal options may also increase the amount of unregulated and unpermitted disposal of the waste.

The most effective incentive to increase the recycling of $C \& D$ waste by contractors and waste handlers is to make recycling financially competitive with conventional disposal. Financial incentives that offer compensation for separating or reusing materials that would otherwise end up in a landfill would reduce the amount of landfilled materials. Nonfinancial incentives may be include code or zoning requirements for source separation and recycling.

Some indirect incentives to increase recyding include: developing procurement standards for recycled-content building materials, including specified percentages of product, constituent materials, banning DA purchase of nonrecycled content materials, and requiring waste reduction programs for DA contractors.

From a regulatory agency viewpoint, restricting the disposal of $C \& D$ wastein either demofills or MSW landfills will tend to increase the amount of waste diverted to alternative methods. One method of restrictive control of disposal is increasing tipping fees for disposal at demofills or MSW landfills. The increase in tipping fees will make recycling more financially feasible.

\section{Recycling Economics}

Army Technical Manual 5-634 States that the economic feasibility of a recycling program depends on whether the added costs (increased time, effort, and equipment) associated with the recycling program are less than the avoided costs (tipping fees, surcharges, labor, hauling fees, maintenance, permit fees, and taxes) plus sales revenue (TM 5-634, p 4-79). If the added costs exceed avoided costs plus revenue, the operation should not be undertaken (Eq 1). 
Added Costs $>$ Avoided Costs + Sales Revenue

[Eq 1]

It is therefore critical that careful economic analysis be performed to determine whether a project should include a recycling program. An economic analysis is required by the Department of the Army to establish the amount of funding required to rent or procure operating equipment and facilities for the project.

According to SWANA, the value of the final marketable waste, or market price, is determined by the cost of competing products at the point of application. This "free market price" (MP) is based on the following factors (SWANA 1993):

$$
M P=M C+P C+T C+P
$$

[Eq 2]

Where:

$$
\begin{aligned}
& \mathrm{MC}=\text { material cost } \\
& \mathrm{PC}=\text { processed cost } \\
& \mathrm{TC}=\text { transportation cost } \\
& \mathrm{P}=\text { profit. }
\end{aligned}
$$

Material costs include the cost of procuring the raw waste stock from the generator. Processing costs generally depend on the sophistication of the equipment and the amount of labor required to handle, process, and prepare/package the products. Overhead costs, such as administrative costs, should also be computed in the processing cost. Transportation costs depend on the distance from the site of processing. The greater the distance to its market, the greater the market price for the goods. Transportation costs will be based, partly, on the density of the material being transported. If the hauler charges by volume (cubic yards), materials such as expanded polystyrene or scraps of lumber will cost more to transport since they require more volume per unit of weight than other, denser debris. Transportation costs can be the most important factor in the market price. Profit is set by the processing facility to cover the risk involved in operating a waste processing facility. Once the free market price is calculated, this information can be used to compare the products with those produced with "virgin" materials.

Some recovered products will have higher value than others. This value will only be realized if the market for the product exists within an economical transport distance and if the "incremental cost of producing the higher value product is less than the incremental higher value of the product" (SWANA 1993).

The level of economic analysis will depend on the scale and scope of the recycling operation. If the extent of the operation is to simply prepare waste materials by sorting on-site, then the analysis should not be more involved than determining: (1) the cost of labor and equipment needed to separate the waste (added costs), (2) 
the hauling, permit, and tipping fees of disposing of the material in a landfill (avoided costs), and (3) any revenue expected from sale of the debris. If the added costs are less than the avoided costs plus the revenue, then it would be cost-effective to separate the waste and sell it to a recycling facility.

Economic analysis for larger recycling operations should be more extensive, particularly if it will involvethepurchase of equipment or facilities. Figure 5 shows a sample economic analysis worksheet from Army Technical Manual 5-634.

\section{Market Analysis}

The identification of markets for the $C \& D$ waste diverted from the waste stream is a critical component of the $C \& D$ recycling plan. "Oncea market exists, the material is no longer a waste but a commodity" (Kibert 1994). The economic success of a recyding program depends primarily on the use of a stable, profitable market. Appendix $A$ lists $p$ otential markets for each class of raw $C \& D$ material.

SWANA suggests that, to have a market for a recycled product, five requirements must be met and agreed on between the buyer and the seller: (1) specifications, (2) quantity, (3) delivery conditions, (4) price, and (5) commitment (SWANA 1993).

The material specification for the end market should reflect the required condition of the waste material at the end market. The specification should includea general description of the waste(s). It is very important to determine this before execution of the recycling program because it will affect how the entire project is planned including the method of storage, job site handling, and any preprocessing needed prior to delivery to the market.

As mentioned previously, the determination of quantities of each class of materials is critical to planning and executing a recycling program. The contractor/project manager will need to indicate an estimate of these quantities before distribution of the waste materials if the quantities are significantly high. This will allow the market/processor to determine whether delivery of the waste will require special handling.

As described in Chapter Two, the quantity of demolition material can be estimated by performing a "reverse" material take-off on the building or portion of the building. There are many cost-estimating guides available to construction managers that convert material and assembly quantities to unit costs. This 
information can also be used to roughly determine, by square foot of floor space, the quantity of demolition materials.

Installation:

Preparer:

Location:

Target recyclable material:

Tons-lb-gal-ea/project:

\section{ESTIMATED ADDED COSTS}

1. Source separation and material preparation

a. Equipment (amortize over life of equipment)

b. Labor

(1) Procurement (amortize over life of equipment)

(1) Operations

(1) Maintenance

c. Other (materials, supplies)

Subtotal:

2. Collection and storage

a. Equipment and facilities (amortize over life of equipment or facility)

b. Labor

(1) Procurement (amortize over life of equip. or facil.)

(1) Operations

(1) Maintenance

c. Other (materials, supplies)

Subtotal:

3. Project administration

a. Instructions and operating procedures

b. Fiscal management

c. Other (publicity, supplies)

Subtotal:

TOTAL ADDED COSTS:
$\$$

$\$ \quad$ /pro.
$\$ \$$ /pro.
$\$ \$$ /pro.
$\$ \quad$ /pro. $)$

$\$$ /pro.

$\$ \quad$ /pro.
$\$ \quad$ /pro.
$\$ \quad$ pro.
$\$ \quad$ pro.

$\$$ /pro.

$\$$

(\$_pro.)

$\$$ /pro.

\section{ESTIMATED AVOIDED COSTS AND REVENUE}

1. Savings resulting from reduced volume of waste going to disposal facilities

2. Sales revenue (tons-lb-gal-ea/project) $\times$ (\$/ton-lb-gal-ea) Subtotal:

TOTAL AVOIDED COSTS + REVENUE:

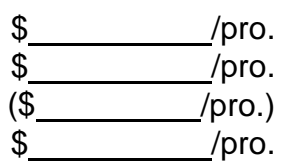

ESTIMATED RETURN

(Total Avoided Costs + Revenue $)$ - (Total Added Costs $)=$

$\$$ /pro.

Figure 5. Worksheet for determining waste sales economic analysis (Adapted from Department of the Army Technical Manual 5-634). 
Delivery conditions describe the type of transport/hauling required by both the contractor and the end market. Issues such as the type of transport vehicle, the containers, and the timing of the delivery need to be agreed on before the delivery.

Market price for recyclable materials depends on the cost of storage, collection, transportation, and other costs of the processor. The demand for these materials is the most important factor (and depends on short-term demand for and availability of virgin material). The scarcer a resource is, the more economically feasible the recovered materials will be. At least six key factors drive the supply, demand, and pricing of recycled materials:

1. Export markets. The Far East, where fiber is in short supply, represents a particularly strong export market for recycled materials.

2. Virgin capacities and recycl ed capacities. When price and availability of virgin commodities change, the price and availability of recycled commodities follow.

3. Geography. A West Coast generator with access to markets in the Pacific Rim has different opportunities than a generator int he Midwest.

4. Transportation costs. The distance to market plays a role in the pricing of all commodities, whether recycled or virgin.

5. End product demand. Recycled materials serve three key sectors of the economy: automobiles, housing and retail. When the auto industry booms, so does thesteel and plastic industries. When housing booms, business increases for suppliers of steel, paper, plastic and other virgin and recycled materials. Likewise, when retail sales dimb, so do paper and plastic packaging material sales.

6. Natural disasters around the world. When a community begins to rebuild after a natural disaster, demand for recycled materials in all areas spike up (Fickes 1997).

The final requirement is an explicit commitment between the general contractor or project manager, hauler, and market. For large scale or long-term projects, this should be in the form of a contract that states each party's requirements. Having a prearranged agreement will reduce the amount of uncertainty associated with the recycling program. 


\section{Salvaged Building Materials and Systems}

As mentioned previously, the re-use of $C \& D$ salvage has occurred for centuries. In most cases, this has been in the form of salvaging the materials from one building for use in other construction projects. When resources were scarce, many indigenous or vernacular builders salvaged components from existing buildings for new construction.

From the point of view of the construction industry and solid waste management, salvaging materials has several advantages. First it recovers the highest percentage of the "embodied" resources in the materials or subsystems. Theenergy and raw materials consumed in the original manufacture of the materials or systems are not lost to landfill disposal. Second, salvaging reduces the total cost of materials since only the cost of removal, refurbishing, and transport are incurred by the salvage.

Also important is that many State and regional waste authorities restrict disposal of bulk waste such as furniture, appliances, and building equipment to special solid waste handlers or landfills. This, in turn, has driven up the disposal tipping fees. In most cases, any level of salvage reduces the cost of disposal.

The Department of the Army uses theDOD's Defense Reutilization and Marketing Office (DRMO) to manage the reuse of reusable equipment and building materials. The DRMO has the responsibility to provide technical assistance to installations in the identification, collection, and storage of scrap materials. There is no Army regulation that specifically governs a systematic building material salvage operation. However, the Defense Reutilization and Marketing Manual, DOD 4160.21-M, does provide good technical assistance on the identification of markets and organization of a large-scale scrap operation.

Several barriers must be overcome to increase the salvage of building materials during $C \& D$ projects. First is the difficulty in identifying markets, or outlets, for the materials. Although this is an essential aspect of all recycling/salvage projects, the resources and time required make the analysis difficult for project managers. Market identification, described below, first entails inspecting the target building and analyzing the expected waste materials for their salvage potential. 
A second barrier for a systematic salvage operation is determining whether the material and/or assemblies can be removed in a cost-effective and safe manner. This information is vital to determining the economic feasibility of the project.

Another barrier is the amount of salvaged material from each project. If there is not enough material to financially justify a full fledged salvage disposal operation, the operation may not take place despite the existence of outlets/markets for the material. A lack of storage space until disposition can prevent a salvage operation if there is too much material. In some cases, the material may have to be stored for an indefinite period of time. Some classes of materials, such as wall board, degrade and become unusable over time and lose their economic value if not stored properly.

The time required to adequately remove the materials and components is another barrier. Construction and demolition projects typically have tight schedules. Once a bid for a project has been accepted and the notice to proceed is issued, work usually begins immediately. It is the responsibility of the project manager to schedule an adequate amount of time for the salvage operation.

Another barrier is the necessary timing of the salvage operation during the $C \& D$ activities. The ideal time to salvage materials is before construction or demolition begins. This avoids conflicting activities between the work crews. The problem is that, in some cases, a certain degree of demolition must occur to make the salvaged material accessible.

\section{Fort McCoy Case Study}

Fort McCoy implemented a successful building salvage program in 1992. The Directorate of Engineering (DE) at Fort McCoy developed a program to remove WWII "temporary" wood buildings in response to the installation's Facility Reduction Program. Besides thetypical Fixed Firm Requirements contracts let for demolition and building removal, the Fort McCoy DE advertised Individual Demolition Service contracts. The DE recognized the need to reduce the costs involved in demolition of buildings targeted under the FRP and the one-for-one MCA matching requirements. They also realized the importance of recovering valuable dimensional lumber and timbers from the World War II structures. The objective of the individual demolition program is to "demolish the buildings at the lowest cost to the Government" (Fred Weiner, Fort McCoy, WI, professional discussion, 1992 [hereafter referred to as "Weiner 1992"]). 
The premise of the program at Fort McCoy was to allow local individuals (e.g., homeowners, farmers) to bid for the salvage rights to a variety of buildings such as barracks, administrative offices, theaters, and mess halls. The Fort McCoy DE felt that there were persons in the community willing to exchange their timeand effort for low cost, well-maintained lumber, equipment, and bricks. Once the DE accepts the bids for the individual service contracts, the contractors have a limited amount of time to remove any materials contained within the building, such as lumber, equipment, bricks, flooring, wiring, and pipe. Fort McCoy removes any friable asbestos, provides a roll-off dumpster and technical information, and performs the final clean up, including the foundation and piers. Figure 6 shows a wood-framed barracks being deconstructed. Figure 7 shows a wood-framed mess hall under deconstruction and the mechanical equipment that came with the building.

The cost savings (cost avoidance) from a salvage program are illustrated in Table 5 using average values provided by Fort McCoy. The actual cost for the 126 buildings originally contracted from mechanical demolition was $\$ 5.79$ per square foot of floor space. Using F ort McCoy's method of deconstruction for salvage and recycling, the cost per square foot of floor space was $\$ 1.61$. To date, over 100 of these buildings have been deconstructed for salvage with the current cost for debris removal and site clean-up, including restoration seeding, totalling only $\$ 1.80$ per square foot of floor space. The cost of mechanical demolition continues to increase and now runs in excess of $\$ 7.00$ per square foot of floor space in a typical commercial demolition contract (Fred Weiner, Fort McCoy, WI, professional discussion, 1997).

As the table shows, salvage can dramatically reduce the cost of facility reduction. As an added benefit, these Individual Demolition Service contracts have provided an inexpensive source of building materials for the local community. Churches, homes, and garages that might have not been otherwise built due to the high cost of new building products were constructed from these salvaged materials. Some of the other indirect benefits of the program include using less landfill space and a reduction in the use of virgin wood resources.

The DE and Fort McCoy Planners/Estimators developed the Individual Service contract specifically for this program. The original commercial program contracts required the potential contractors to retain a bid bond. The DE felt that this requirement excluded theindividuals they believed would bemost interested in this program. Thetypical Corps of Engineers demolition bid package contains a myriad of forms and procedures, particularly if the bid includes provisions for special waste handling such as asbestos abatement. It was felt that this will also reduce the 
notification of the individuals who would be most interested in salvaging the wood and other materials in the buildings. 


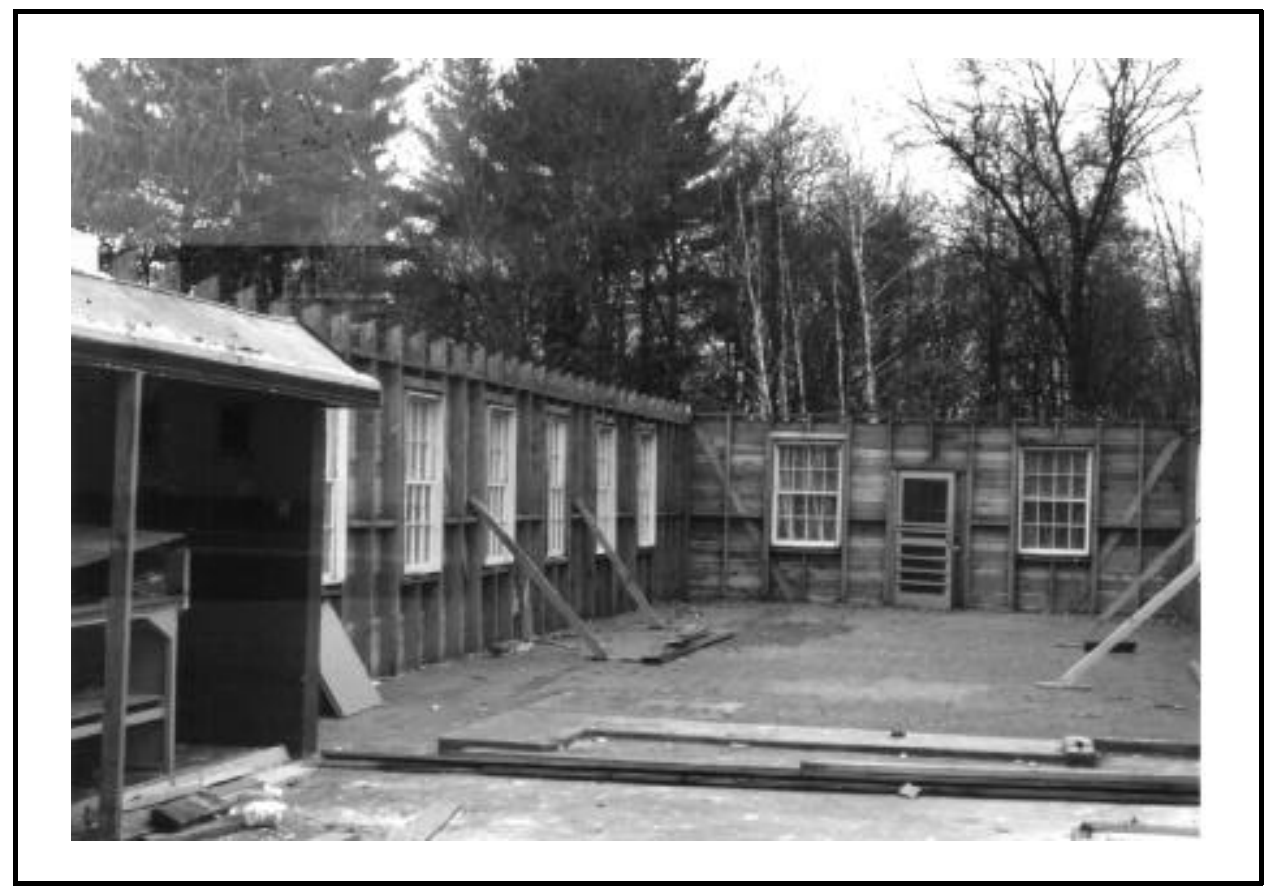

Figure 6. Wood-framed barracks in process of deconstruction.

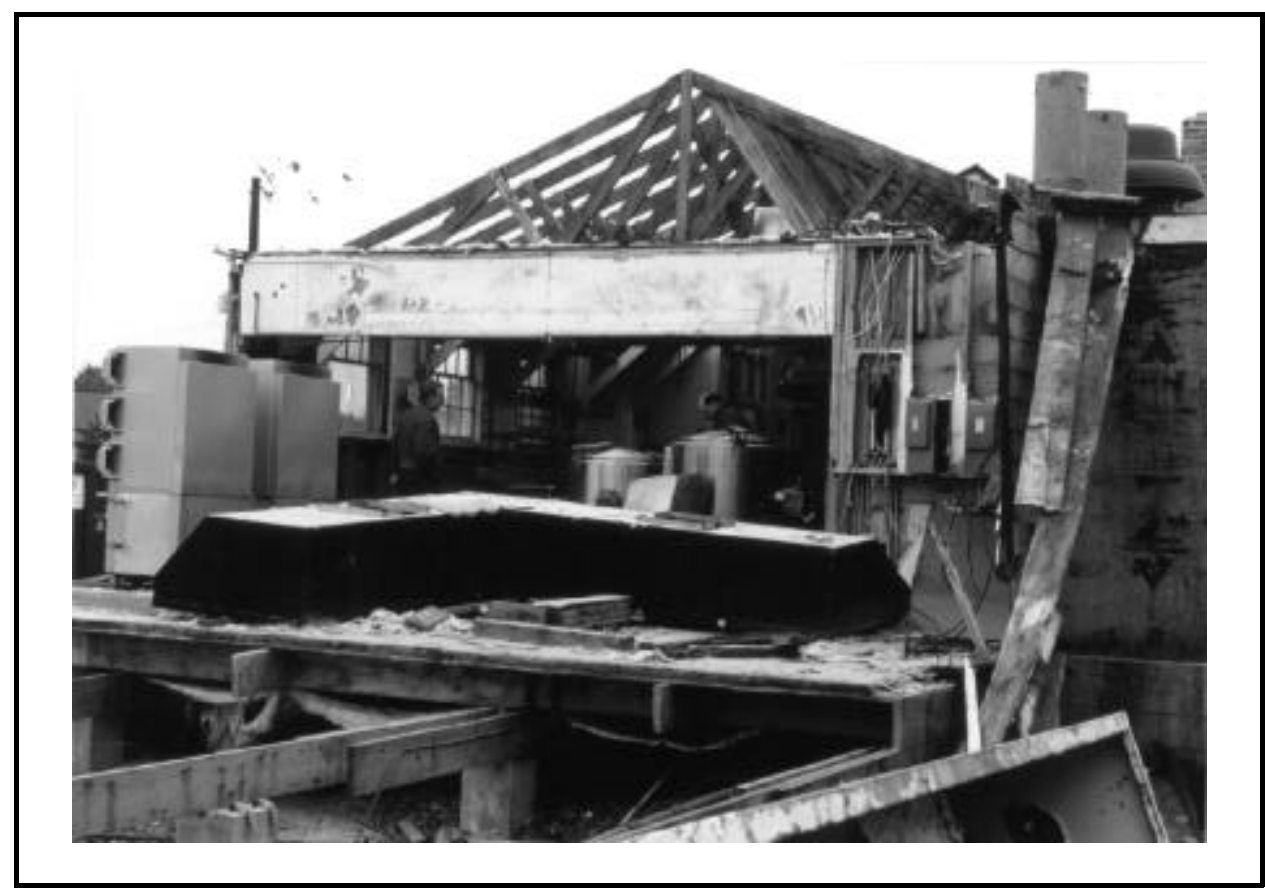

Figure 7. Wood-framed mess hall in process of deconstruction. 


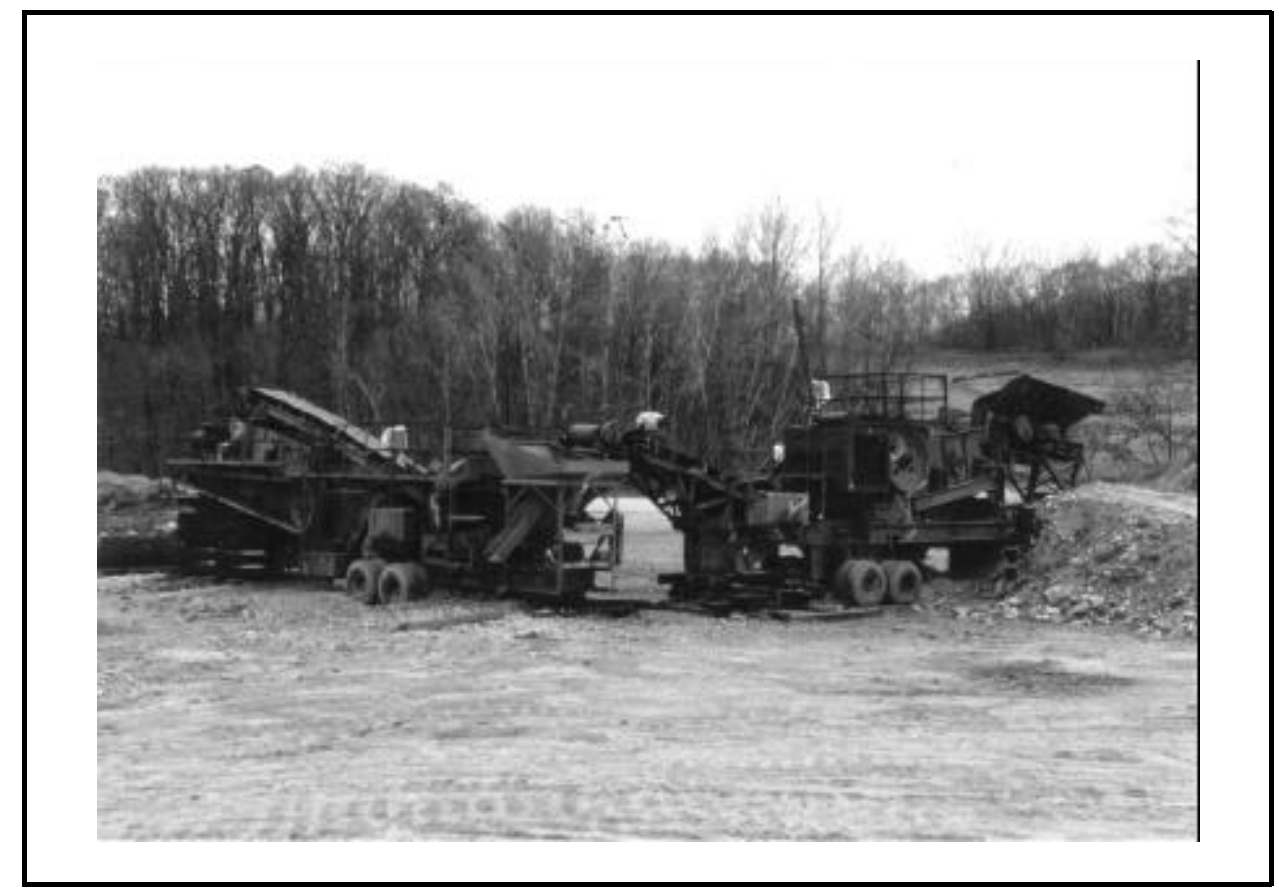

Figure 8. Equipment used to grind building foundation materials for future use on the installation.

Table 5Cost savings with F ort McCoy WWII salvage program.

\begin{tabular}{|l|c|}
\hline Floor Area & $3,500 \mathrm{sq} f \mathrm{ft}$ \\
\hline Board-feet of lumber & 18,300 board ft \\
\hline Tons of debris & 45 tons \\
\hline Cost of commercial demolition & $\$ 40,000$ \\
\hline Cost of landfill disposal & $\$ 1,800$ \\
\hline Total commercial demolition cost & $\$ 41,800$ \\
\hline $\begin{array}{l}\text { Cost of building salvage, including administration, } \\
\text { supervision, use of heavy equipment. }\end{array}$ & $\$ 5,600$ \\
\hline Cost savings from salvage vs. demolition: & $(\$ 41,800-\$ 5,600)=\$ 36,200$ \\
\hline *All values are per one typical building & \\
\hline
\end{tabular}

The Individual Demolition Service contract requires the bidders to remove roofing and siding before any other materials can be taken from the site. This partially protects the installation from bidders who are only interested in salvaging the most valuable building materials such as equipment, metals, or choice wood. 
Fort McCoy has used the salvage program as an opportunity to improve the training of several technical and engineering units. Engineering units have used the salvage sites to train in excavation, grading, and material processing. Instead of using the local wooded areas for training, the units have been able to train in more "realistic" conditions of a building site. Also, the excavated foundation materials were used as road bed for a new access road on the installation. Figure 8 shows the equipment used to grind up the foundation materials.

According to the DE, several key points to the success of the F ort McCoy building salvage program are (Weiner 1992):

- Environmental and safety considerations need to be addressed through respective Division Chiefs, and legal opinions need to be cleared through J udge Advocates's Office (J AG).

- $\quad$ Adopt thephilosophy that anythingsomeoneel sedemolishes, theGovernment does not have to.

- The individual demolition contract must be managed by on-site personnel rather than outside agencies.

- $\quad$ Make the contract "user-friendly." Keep it simple and easy to understand.

- Remove barriers that may keep small potential customers from bidding, e.g., requiring a bid bond or concrete removal. Provide for removal of the final debris.

- $\quad$ Keep your interests in focus, too. Labor intensive work should be done first before valuable materials leave the site.

- Limit the duration of the contract with the option to extend at the discretion of the Contract Office Representative, based on the past performance of the contractor.

- $\quad$ Be creative! The objective is to get the buildings down at a minimum cost to the Government.

- Know the needs and wants of your community. Remember, potential bidders want buildings to save money on materials.

\section{Project Planning for Salvage Operations}

Perhaps the most important issue for planning a salvage operation is identifying in-situ that materials can besalvaged. Thetwo criteria that must be considered are whether there is a market or outlet for the material or assembly, and whether the material meets the specification of the market. The salvage manager evaluating the demolition project must identify potential salvageable materials and plan how the materials will be removed. Project planning for salvage is very important since 
there is typically little time in a demolition project for the salvagers to work. I ssues that must be addressed include:

- $\quad$ identification of salvageable materials, equipment, and assemblies/components

- $\quad$ identification of special removal or technical issues

- $\quad$ application of permits from local or State authorities, where applicable

- contracting for salvage contractor

- $\quad$ identification of secure storage area.

It is difficult to create a comprehensive list of the types of materials, equipment or assemblies that can possibly be salvaged since the most important factor is the existence of a market or the materials. Materials and subsystems that may have little value to one project may be of great value to another. Some of the most common items that are kept out of landfills are ceramic tile, windows, lumber, molding, plumbing fixtures, sinks, and kitchen cabinets. Salvage operations can find new homes for this C\&D waste.

TheDRMO may assist the project manager to organize the disposal or redisposition of useable equipment. According to Army Technical Manual 5-634, the DRMO supports a recycling program by:

1. Conducting market research to determine proceeds from the operation

2. Providing advice on procedures for collecting, segregating, and storing materials to optimize sale proceeds

3. Assuming accountability for materials made available for sale

4. Determining whether materials turned in under the recycling program shall be diverted to higher priority program

5. Conducting sales and depositing the proceeds in the program account.

In the same manner, the identification of special requirements, such as asbestos removal or material of unique quality will depend on each project. The installation should determine what markets exist, if any, and prices associated with markets (AR 420-49). According to AR 420-49, an installation may directly sell recyclable materials acquired with appropriated funds if the direct sale is expected to be cost effective and 100 percent of the proceeds from the sale will be credited to the installation.

Most local governments have an agency that is responsible for permitting demolition projects. Project managers should check with all applicable local and State authorities to determine their permit requirements. 


\section{Demolition Techniques}

\section{Recycling Considerations in Demolition}

Demolition is the systematic total or partial removal of structural systems, subsystems, and materials from a building. The method of demolition used to remove materials from a facility has a significant impact on the recyclability of the waste materials. The economic feasibility of a recycling project depends on the amount of handling and processing necessary to condition thegoods according to the needs of the markets. In essence, the more mixed the waste, the more separation required before processing the waste. This additional processing increases the final cost of recycling the waste. Most techniques have been devel oped to perform the demolition quickly and efficiently. Any amount of "processing" of theraw wreckage, such as shredding or grinding, should be done to decrease the cost of transport by reducing volume. I deally, this means that all materials are demol ished at the same time and into the same pile of material. Any post-demolition separation that occurs at this point involves mostly recovery of scrap metal or removal of any material that may substantially increase the cost of disposal, such as hazardous materials.

Thereare threetypical approaches to building demolition: (1) manual wrecking; (2) mechanical wrecking; and (3) explosive charge demolition.

\section{Manual Wrecking Methods}

Manual wrecking describes the methods used by contractors generally without the assistance of heavy equipment. Manual wrecking generally occurs on either very small projects that do not warrant contracting a bulldozer or front-end loader, in high density residential or industrial areas, or on partial-demolition projects such as interior remodeling. Manual wrecking involves the "systematic hand removal of materials from a given structure" (Murthy and Chaterjee 1976). Figure 9 shows the order of activities. Manual wrecking can be very labor-intensive since most of the demolition involves cutting and ripping with hand and power tools.

The advantage of manual wrecking methods is that it may result in debris with the highest salvage and reclamation potential. Materials and assemblies can be systematically removed and prepared for disposition. Although manual wrecking 


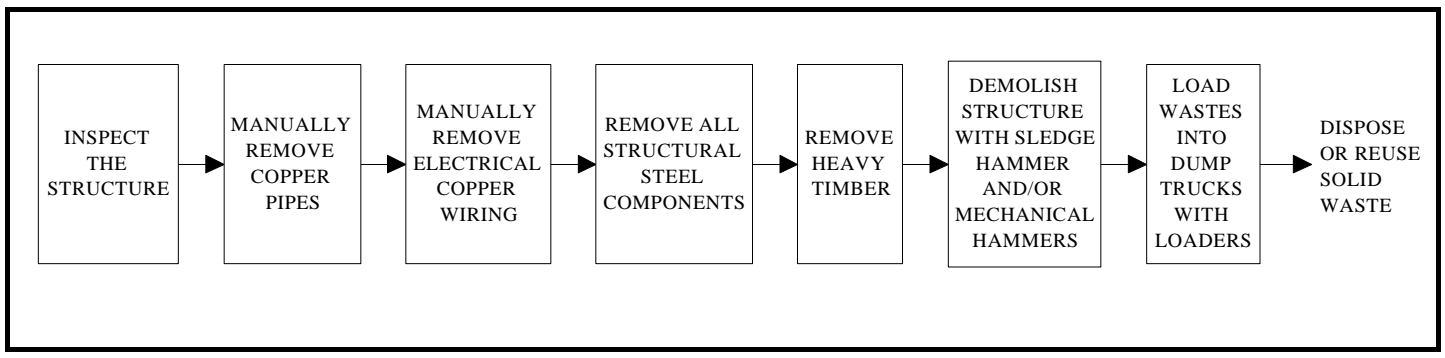

Figure 9. Steps in manual wrecking.

is cost and time intensive, the expense of this method may be offset by the money gained from sale of the reclaimed materials. Of course, if the costs cannot be recovered (including some profit) and/or if the construction schedule is tootight, the likelihood of salvage and recovery of the buil ding components is greatly diminished.

\section{Mechanical Wrecking Methods}

Mechanical wrecking is the most common method of building demolition. It is both efficient and cost effective compared to manual wrecking since it substantially improves labor productivity. There are several different types of mechanical demolition techniques and equipment (Table 6). The use of each method depends on thetype of structure, cost, safety and health issues, and local zoning constraints.

The amount of material that can be salvaged after mechanical wrecking methods is usually very low. The use of a bulldozer or front-end loader will typically crush and mix the materials, eliminating the possibility of salvaging the materials in their original condition. The recyclability of the materials depends on whether the condition of the materials makes them unusable, and the amount of separation that can be performed after wrecking. Murthy and Chaterjee (1976) suggest different strategies for improving the separation of goods by using equipment such as grab buckets or mechanical claws that are capable of some separation of the materials from the structure. In the same manner, some techniques, such as the use of hydraulic splitters for concrete and flame cutting for steel, can be efficient means to separate materials before general demolition of the building.

Table 6Mechanical demolition techniques and equipment.

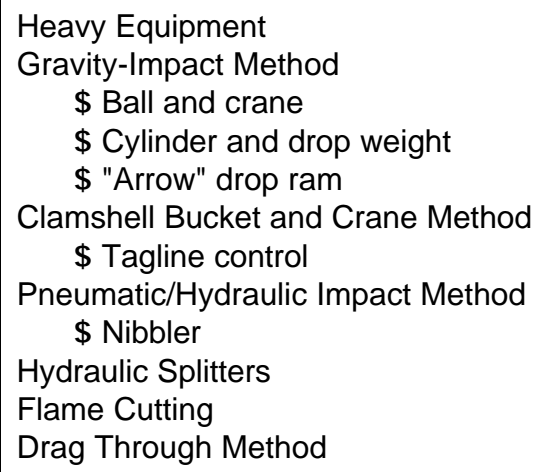




\section{Explosive Demolition Methods}

Explosive demolition techniques are used for specialized projects such as shearing wood piles, posts or timbers, or large, multi-story buildings. Explosive demolition generally results in the lowest recyclability and salvage potential for all buildings except primarily reinforced concreteand masonry buildings. Thetechniques include the use of:

- $\quad$ shaped charges

- linear shaped charges

- controlled blasting.

\section{Criteria for System Selection and Evaluation}

The selection of a wrecking technique that will maximize the recycling potential of its materials depends on two factors: (1) amount of systems and materials that are salvageable, and (2) the potential to preseparate or to makeseparation of materials easier. These factors have to be bal anced against the other issues concerning choice of demolition techniquesuch as cost, availability of equipment and expertise, safety, and time constraints. Analysis of the method of demolition as Stated in Army Technical Manual 5-634: "the final choice of methods or combination of methods should be based on least cost where such studies are conclusive while in accordance with local, State, and Federal requirements." 


\section{Debris Handling}

The manner in which the waste materials are handled during and after construction/demolition have a significant impact on the economic viability of the recyding program becauselabor and equipment costs of preselection and sorting are relatively high. Despite the other preconstruction planning issues that this report has addressed, the actual quantity and composition of the waste will not be known until it is being generated. To avoid increasing the cost of disposal, waste material that cannot be recycled or that has no preidentified markets should not be handled differently than thenormal wastedisposal procedure. Proper handling and storage will simplify quantification, collection, and resource recovery.

The critical factor to consider in debris handling is the efficient collection and disposition of the materials into the appropriate storage containers or area. Avoid contaminating of the material during handling, such as allowing the material to sit on the ground or to mix with other classes of materials. The waste should be collected and handled in a safe and healthy manner.

Storage is also an important issue since the cost of frequent hauling to the market may be cost prohibitive if the project is a great distance from the point of final disposition. Some organic wastes, such as wood waste, are especially difficult to store and protect against deterioration.

Special waste materials such as hazardous waste, including fluorescent lamps, asbestos, containers, etc. may warrant careful handling. USEPA regulations require the generator of waste to determine whether the materials are hazardous. Lighting components, such as outdated ballasts and lamps, are not obvious hazardous materials, but they do fall under many State and Federal waste regulations (Leishman 1996).

\section{Project Planning for Debris Handling}

Recycling operations will not only require some market analysis, but also a great deal of planning by construction management. The variability of recycling economics demands that management preplan the project as much as possible to 
reduce the likelihood of unforeseen problems from upsetting the project. Although every construction and demolition project will be different, project managers, installation engineers, and contractors should consider the following factors:

- layout of collection area

- collection

- contract issues for disposal, hauling, etc.

- material separation and/or preprocessing

- handling hazardous waste.

\section{Collection Area Layout}

Some materials, such as gravel and rubble, do not need any special considerations to store on site. This type of waste does not need to be covered. Other types of wastes, such as cardboard or gypsum board waste are not water-resistant and will deteriorate if left exposed to the elements. Many processors will not accept wet waste since its weight and characteristics make it difficult to process. Also, since some raw materials are purchased by the pound, processors may not accept excessively heavy, wet stock. The issues that must be addressed for site storage of the materials are:

- containers, including capacity

- cost/fees for containers

- location.

Most construction sites require larger containers because the volume of the debris is much greater than other types of solid waste. The size and type of containers depends on the nature of the waste to be contained. Flexible waste materials like cardboard or wall board may be able to folded or broken into pieces and placed in smaller, portable containers. Larger, inflexible materials such as wood or metals, will require containers with enough capacity to accommodate their size while minimizing the need to process the materials to fit the container.

The anticipated length of time of storage of the materials also has to be considered in selection of the containers. If materials must bestored for longer periods of time, Army Technical Manual 5-634 requires that they must not constitutea fire, health, or safety hazard. Thetypes of containers that are used for $C \& D$ waste typically use include:

- manually-loaded lugger boxes 
- enclosed, compaction-type containers

- roll-off containers

- $\quad$ open top, trailer-mounted containers.

The location of sitestorage is an important consideration since large scale recycling will generate a great deal of waste. The location has to be convenient for workers to use when disposing of the material. A location too far away from the work area may increase the amount of time taken to dispose of the material. This may affect the time required to complete the project.

The choice of location also has the potential to disrupt vehicular and pedestrian circulation on the site. Location of the waste debris storage also has some impact on economic feasibility of the project since it may require more time and effort for the hauler to retrieve the debris from their containers. Solid waste managers carefully develop a plan for waste pickup for curbside collection programs.

As with choosing a container, the project manager must consider the composition and quantity of the waste in choosing a location to store the materials. Most inert wastes must be piled or stacked in a location on the project site that has convenient access for loading onto a trailer.

There are several options for hauling waste materials from the generating site to either the transfer station or the end market. The most common method is by truck. The hauler will either pick up the storage container(s) or will load the material into an open trailer. Other options for transportation are by barge and rail. Both of these options are typically used in special circumstances, such as when very large quantities are involved and when the project is in close proximity to existing transportation.

\section{Debris Collection}

Debris collection for recycling entails daily collection/deposit of waste materials in storage containers and subsequent collection of the aggregate waste by a waste hauler. All considerations must comply with debris collection guidel ines in AR 42049. The collection frequency will be established in accordance with TM 5-634. Special collection arrangements and handling procedures need to be established for unique installation activities that produce waste that is different from what is normally collected and disposed. Events such as unit relocation, building demolition, new construction, and base closure and rehabilitation action can affect 
the number of containers and collection schedules required to dispose of waste (AR 420-49).

Project management should be primarily concerned with the logistical issues involved in the collection of waste. The most important factor to consider is the timing/frequency of collection. Scheduling the collection should balancethecapacity for storage on site with the cost of more frequent hauling. The fee that the waste hauler charges may depend on the distance to the processing facility or transfer station. Therefore, the greater the amount of material to haul to a recycling facility the more cost effective the collection. An important issue to consider, though, is that the longer the material remains on site, the more likely that is may become contaminated with nonrecyclable materials, or degrade from exposure to the elements.

Construction site waste management usually entails depositing the waste in a lugger box or roll-off somewhere close to the work site. As mentioned previously, to maximize the amount of recyclable material, every effort should be taken to separate materials before they are deposited in the collection containers.

\section{Contract Issues}

Contracting for hauling is the responsibility of the project contractor. Contracts for salvage operations need to be negotiated to include personal injury liability, including coverage for power equipment and motor vehicle operation. For liability purposes, a salvage contractor should seek to be the general contractor in appropriate projects. Under certain circumstances (e.g., demolition of high-rise or masonry structures), a salvage contractor may enter the project as a subcontractor for predemolition salvage or post-demolition scavenge. Other contract-related issues include determining insurance requirements and specifying the salvage operation. If necessary, a liquidation firm may be used.

\section{Material Preparation}

Separation of the materials is the most common aspect in material preparation. Segregation of the waste enables the individual materials to be directed to the appropriate markets. The more separation that can be done at the source, the less processing and handling will be required at some later point. The economic integrity of the operation can be enhanced by the intelligent management of the waste while it is being generated. 
Separation of the waste entails both breaking the materials into their constituent components and deciding the disposition of the waste at the point of generation. Each person involved in the handling process, whether as a generator, or later, as someone who must dispose of the materials, must be able to determine whether the material qualifies for recycling. Some materials, such as shrink wrapping, discarded paint brushes, etc., cannot be feasibly recycled. These wastes should be disposed in the normal manner. Actual processing of the waste debris (i.e., grinding, etc.) is covered in the next chapter.

Transfer stations are the intermediary location for storage or preprocessing of solid waste. Transfer stations are typically needed when the final location for disposal or recycling is a great distance from the generator. The intermediate location can collect the material until a sufficient quantity of material is accumulated to economically transport the waste to its final disposition. The waste may be subjected to some form of processing, such as shredding, at the transfer site to reduce its volume and reduce the cost of transport. Municipal solid waste transfer operations, for example, compact and bale materials awaiting shipping to a recycling center. If the transfer stations are used to perform some processing, such as separation, on the waste they may simplify the material requirements of the generator. This may, in turn, increase the amount of participation of the generators.

Transfer operations range from a simple, centrally-located loading dock for collection vehicles unloading, to complex facilities requiring capital equipment such as unloading/sorting machinery. C\&D waste transfer sites can be both temporary and permanent installations, depending on the life and scale of the project.

The use of a transfer station for recycling C\&D waste would depend on the expected life of the construction and demolition projects, their scale, the density of the project, and its location to end market producers or processors. Long-term, remote site construction projects (3-plus years) may have an extended life and produce enough waste material to warrant the capital expense of a transfer station. A transfer site may also make sense when a there is no room on the construction or demolition site for storage or separation of the wastes, such as would occur in the case of a demolition project in a densely urban area.

The 1993 flooding in the Mississippi River Valley around Hull, IL caused the widespread destruction of a number of homes and structures. After the demolition water damaged structures, the IL Department of Transportation (IDOT) used a centrally-located transfer station in East Hull, IL as a collection point for demolition materials from as far away as $25 \mathrm{mi}$ ( Lowell Hewlett, Illinois Department of 
Transportation [IDOT], professional discussion, 1993). Because of the amount of material and the widespread nature of the activity, IDOT felt a central location would be best in terms of managing the collection and processing of the waste material.

Although the use of transfer stations to coordinate the collection and recycling of $C \& D$ debris may be beyond the scope of many DA construction and demolition projects, several factors may affect their viability for use on or around an Army installation (Army PAM 420-47):

- large quantity of waste

- availability of site for transfer

- location of the site

- availability of collection and transfer equipment

- final method or location of final disposition of the material.

Developing a transfer operation will require some capital expenditure. Army Technical Manual 5-634 states the economic issues that must be considered are: facilities and site, equipment, and investment costs, including financing. The transfer station will also incur some operating costs such as: materials and supplies, labor costs, equipment rental, cost of utilities, maintenance and repair costs, and permit and closure costs. There will also be the overhead costs of operation such as supervision pay and installation support (Army TM 5-634, sec. 3.2.10).

\section{Handling Hazardous Waste}

Another important factor that must be considered in planning a project is the environmental characteristics of the materials. Gidley and Sack (1984) pose three questions about the waste materials that must be addressed:

1. Does the waste possess properties that make it potentially harmful?

2. Does the waste possess properties that would make it mobile in the environment?

3. Does the final disposition of the waste possess properties that will increase or decrease the likelihood of harmful exposure to the waste?

At least seven attributes make any waste materials potentially harmful: toxicity, infectivity, reactivity, flammability, explosivity, corrosivity, and radioactivity (Gidley and Sack 1984). Hazardous waste is defined in 40 CFR part 261 as a 
substance that is ignitable, corrosive, reactive, or toxic. Ignitable means a liquid with a low flashpoint (a flammable solid or compressed gas), or that is an oxidizer. A liquid is corrosive if it has a $\mathrm{pH}$ less than or equal to 2 or greater than or equal to 12.5. A reactive substance is one that is unstable or that emits toxic gases under normal conditions, or that reacts violently with water. A waste is toxic if the Toxicity Characteristic Leaching Procedure (TCLP) yields a concentration that exceeds regulatory levels established by the USEPA (Test Method 1311). The purpose of the TCLP test is to simulate conditions in a landfill to determine if a given waste would become mobile in the leaching process. The procedure determines the mobility of both organic pollutants ( e.g., volatile organics, semivolatile organics, pesticides, and herbicides), and metals. Most of these attributes have some measurable component that can be tested at the collection or storage site.

The mobility of the waste material after it has been removed from the work site can cause several different environmental impacts. The wastes may become mobile by volatilization, dusting, abrasion, suspension, and dissolution (Gidley and Sack 1984). It is reasonable to assume that an adverse environmental impact will not occur unless the waste has one of the hazardous attributes described above. A significant path of mobility on a construction site is fugitive dust. If the dust is toxic to natural life, increased health problems may result.

The site of $C \& D$ waste disposal has traditionally been either a landfill or backfill. With increased recycling, the final disposition for the material may still be fill, but may also be in the form of other building or consumer products. It is important to consider the final use or disposition of the wastes, particularly if the materials contain some hazardous or restricted materials. An example is the chipping or shredding of finished wood. Lead-based paint is considered a hazardous material, and reducing the wood to small particles make the lead more mobile in the environment. Using this material as mulch or landscape cover should actually increase the exposure of people to the lead than if the material were left in place. The same is true when the hazardous material is reduced to a small particle size; in such a case, the dissolution by prolonged exposure to moisture will increase the level of the material in ground water. Reduction of the waste may also increase the density of its toxic constituent, therefore making it relatively more hazardous.

Appendix I to 40 CFR 260 - Overview of SubtitleC Regulations, is designed to help those who are unfamiliar with the hazardous waste control program to determine with which regulations (if any) they should comply. A series of questions is presented in a flow chart concerning the waste. After following the chart, a person should be able to determine if the solid waste he/she handles is hazardous. 


\section{Lead-Based Paint}

For lead-based paint (LBP) waste to be considered a hazardous waste, it must contain more than 5 parts per million (ppm) of leachable lead as determined by the TCLP test. While other hazardous substances, such as mercury as a fungicide, have been used in paint, lead presents the most serious problem due to its widespread use especially in pigments, which may comprise a major volume component of the paint film. The classification and final disposal of LBP waste depend on its form and source (Cosper, Hallenbeck, and Brenniman 1993). Figure 10 presents a flow chart for determining the status of LBP waste. If individual homeowners remove LBP from their own residences, the resulting waste is consi dered general MSW and is not regulated any further. However, if a contractor is hired to remove the LBP from the same residence, the waste would be considered a special waste, and would be subject toStateand F ederal regulations. When Army facilities containing LBP are demolished, demolition debris will be characterized and disposed of in accordance with Federal, State, and local solid waste management regulations.

Disposal restrictions are based on the possibility that lead content in such wastes may leach into the water table if placed in a landfill. A study done by Gershman, Brickner \& Bratton, Inc. shows that lead is not a major component of demolition landfill leachate even with the high lead paint content often found in older demolition projects (NADC 1995). The adherence of the LBP to a substrate may decrease the amount of leachable lead in the waste. As a result, waste components such as windows, doors, shelves, baseboards, and other trim containing or

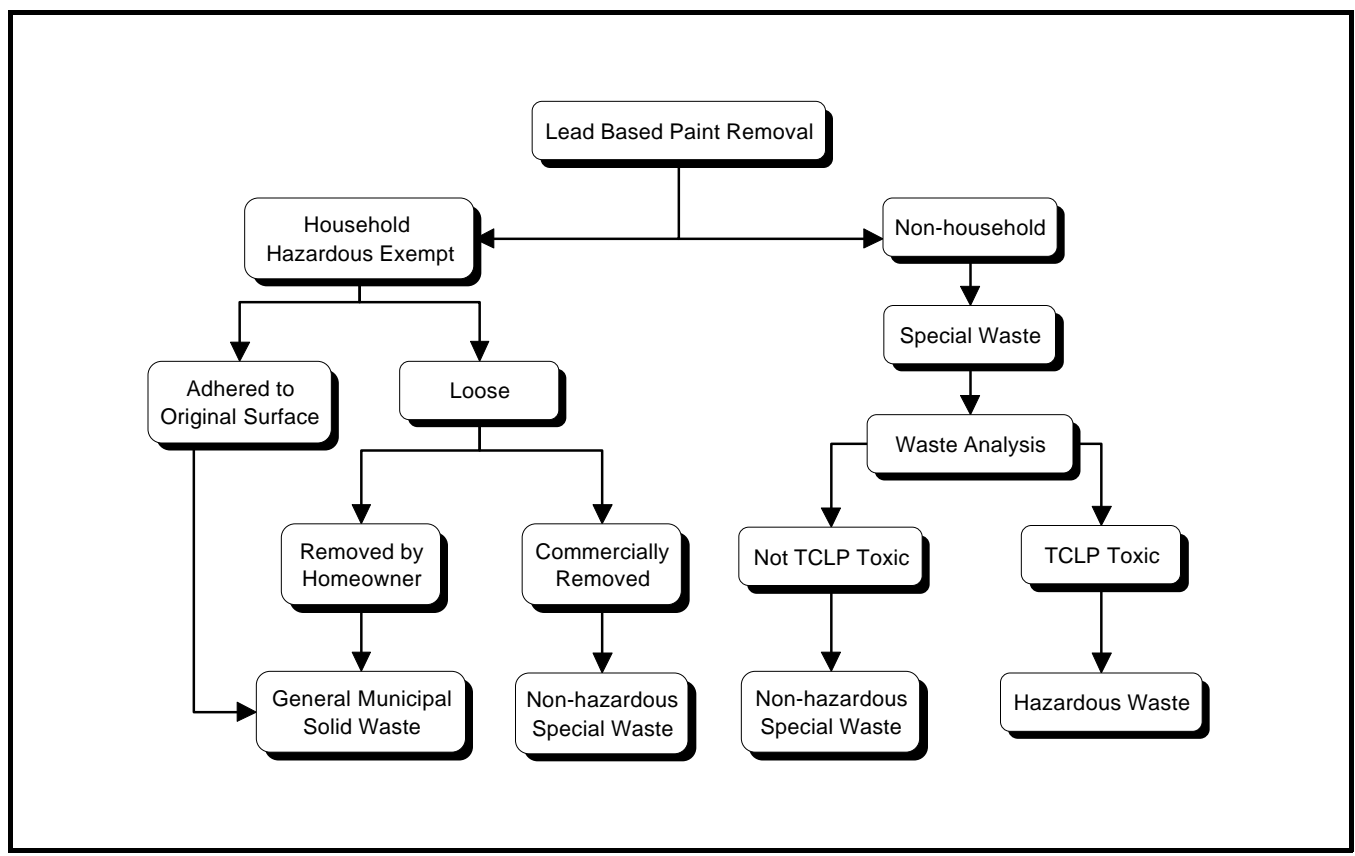

Figure 10. Flow chart for determining status of lead paint waste. 
contaminated with lead-based paint have a low chance of failing the TCLP test. All LBP removed from a substrate by virtually any method will, almost without exception, be hazardous waste and should be disposed of accordingly.

\section{Asbestos}

For regulatory purposes, the USEPA has defined an asbestos-containing material as one that contains greater than 1 percent asbestos. The accepted method of determining whether a sample of a material contains greater than 1 percent asbestos and the type of asbestos present uses a polarizing light microscope. The presence of asbestos in a material does not always pose a significant hazard. Substances that are easily crumbled or reduced to powder by hand pressure are termed "friable," whereas those that do not produce powder by hand pressure, are termed "nonfriable." Airbornefibers present a hazard if inhaled. A friable material would be more likely to produce airborne than a nonfriable material .

Section 112 of the Clean Air Act has a section titled National Emission Standards for Hazardous Air Pollutants (NESHAP), which prohibits the renovation or demolition in many buildings of greater than either $160 \mathrm{sq} \mathrm{ft}$ of asbestos-containing surfacing material, or 260 linear feet of asbestos-containing pi pe insulation without adequate precautions against fiber release. The USEPA has promulgated regulations on the use and disposal of asbestos and removal standards for buildings under renovation or demolition beginning at 40 CFR part 61.140. Accordingly, the owner of a building scheduled for renovation/ demolition or the contractor, must notify the USEPA Air Compliance Branch, asbestos section and provide the following:

- description of the facility and an estimate of the amount of friable asbestos present

- demolition schedule

- $\quad$ asbestos removal procedure

- location for final disposal.

For friable asbestos materials, this means that demolition is only all owed after the material has been removed prior to the start unless it is encased in concrete or it is kept wet during the project to prevent dust emissions. Nonfriable materials can fall under NESHAP regulations if they can become friable during renovation or demolition. If asbestos waste is wetted during removal, put in proper containers, and labeled, it can be disposed of in any landfill. 
Many different types of building materials at one time contained asbestos, such as beam spray, ceiling acoustical texture, joint compound and wall texture, flooring, ceiling tile, piping or thermal system insulation, roofing, cement, and glue, etc. During demolition of an old building, construction workers are at risk from asbestos. Any building from before 1980 can have asbestos in the insulation, fireproofing, floors, walls, or roof. Newer buildings can have asbestos in the roof or floors. If there are doubts whether a building contains asbestos, the Occupational Safety and Health Administration (OSHA) requires you to act as if there were asbestos.

To track compliance with health, safety, and environmental protection requirements, a flow chart can be used an effective communication tool and field guide (Asfahl and J ohnson 1993). This method can be used effectively for asbestos demolition/renovation projects, lead paint removal, and other work covered by Federal and State standards. Figure 11 shows a sample working flow chart for asbestos removal in renovation or demolition work. The numbers assigned to each block refer the chart user to an explanation, contact phone number, or other pertinent information that would be printed on the reverse side of the chart. Using flow charts for managing projects with hazardous materials can bevery hel pful, and can give workers and supervisors confidence that they are in compliance with all applicable regulations at each stage of the job.

\section{Other Hazards}

Many hazardous products are routinely used on construction sites and it is likely that some will find their way into the $C \& D$ waste stream. Table 7 lists possible hazardous contaminants in C\&D waste taken from a study commissioned by the California Department of Health Services (Cosper, Hallenbeck and Brenniman 1993). Many of the materials are associated with painting, solvents, or maintenance products for heavy equipment. These potential hazardous materials may be mingled with materials in the process of to recovery and may create future disposal problems. 


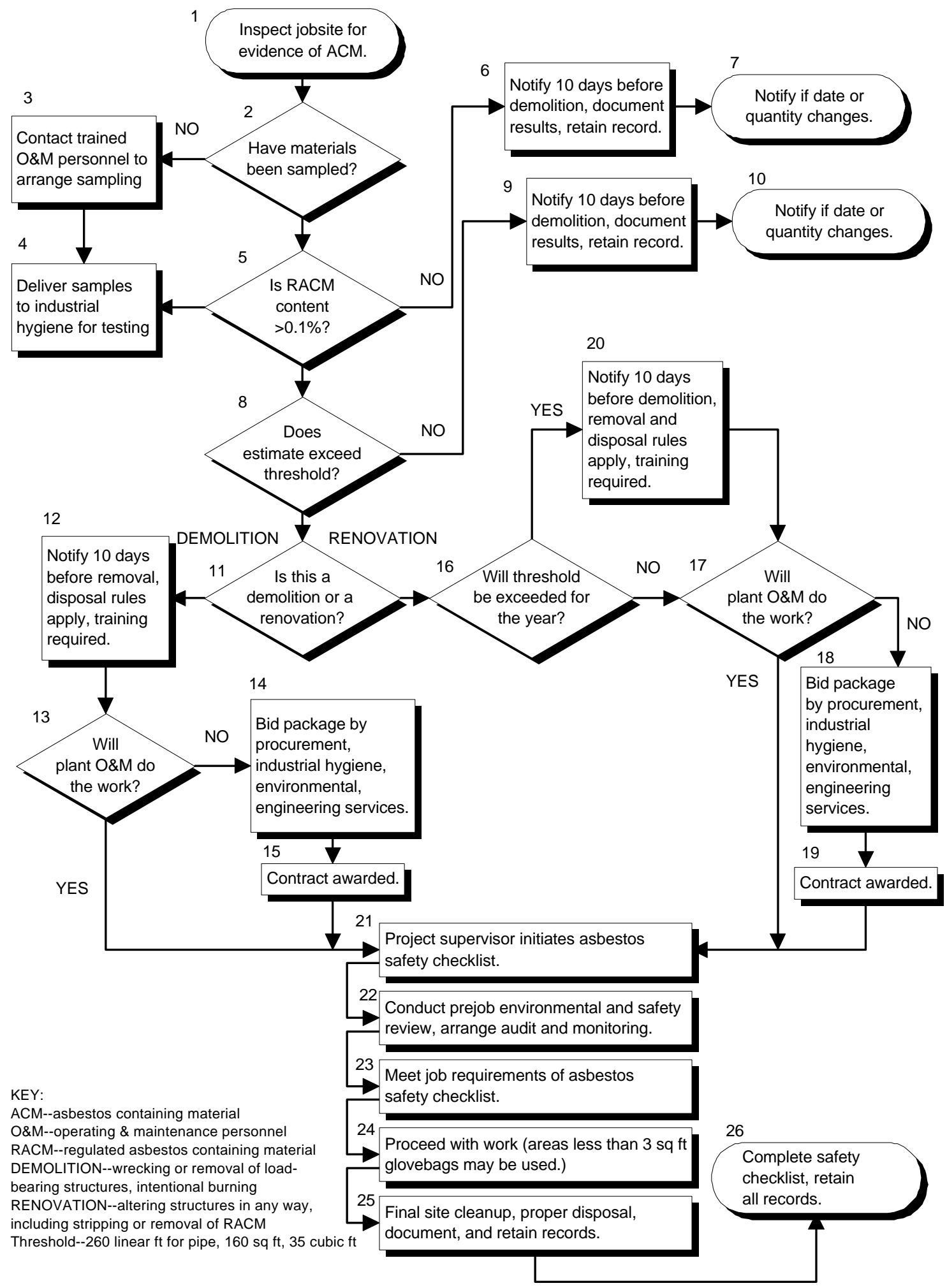

Figure 11. Flow chart for asbestos demolition/renovation. 
Table 7Possible hazardous contaminants in C\&D waste.

\begin{tabular}{|c|c|}
\hline Acetone & Acetylene Gas \\
\hline Adhesives & Ammonia \\
\hline Anti-freeze & Asphalt \\
\hline Benzene & Bleaching agents \\
\hline Carbon Black & Carbon dioxide (in cylinders) \\
\hline Caulking, sealant agents & Caustic soda (sodium hydroxide) \\
\hline Chromate salts & Chromium \\
\hline Cleaning agents & Coal tar pitch \\
\hline Coatings & Cobalt \\
\hline Concrete curing compounds & Creosote \\
\hline Cutting oil & De-emulisifier for oil \\
\hline Diesel fuel & Diesel lube oil \\
\hline Etching agents & Ethyl Alcohol \\
\hline Fiberglass, mineral wool & Foam insulation \\
\hline Freon & Gasoline \\
\hline Glues & Greases \\
\hline Helium (in cylinders) & Hydraulic brake fluid \\
\hline Hydrochloric acid & Insulation \\
\hline Kerosene & Lime \\
\hline Lubricating oils & Lye \\
\hline Methyl ethyl ketone & Motor oil additives \\
\hline Paint/lacquers & Paint remover \\
\hline Paint stripper & Particle board \\
\hline Pentachlorophenol & Polishes for metal floors \\
\hline Putty & Resins, epoxies \\
\hline Sealers & Shellac \\
\hline Solder flux & Solder, lead \\
\hline Solder, other & Solvents \\
\hline Sulfuric acid & Transite pipe \\
\hline Varnishes & Waterproofing agents \\
\hline Wood preservatives & \\
\hline
\end{tabular}




\section{Debris Processing}

Recycling C\&D material will require some form of processing of the raw waste stock. Except for salvageable systems and materials, $C \& D$ waste debris will have to meet the specification of the end markets for which its destined. The objective of processing the waste is to "add maximum value to the overall $C \& D$ waste stream" (SWANA 1993). Most waste materials will need to be either processed to reduce volume or to meet the product grades and market specifications.

\section{Quality Control}

If recycled materials are to compete with virgin materials, processors must deliver high quality products that dosely match the customer's specifications. The key to producing a good product from raw wastestock is quality control. Debris processors may accept waste material from unknown sources or waste material that may be contaminated. Incoming loads of reclaimed material must be inspected, requiring only a quick glance if the source is well known, or a careful inspection if the source is suspect (Cosper, Hallenbeck, and Brenniman 1993). Quality assurance continuing through the sorting process, either manual or automated, is required to yield a homogeneous, uncontaminated product.

\section{Processing Techniques}

Debris processing techniques can be broken intotwo categories: on-site and off-site. The advantage of on-site processing is the reduction in the cost of transporting the materials to their final disposition. Relatively dense waste reduces the amount of equipment needed to transport the material. The methods of on-site processing that could be used for $C \& D$ waste processing are:
- crushing
- grinding
- $\quad$ shredding
- pulverizing.
- chipping 


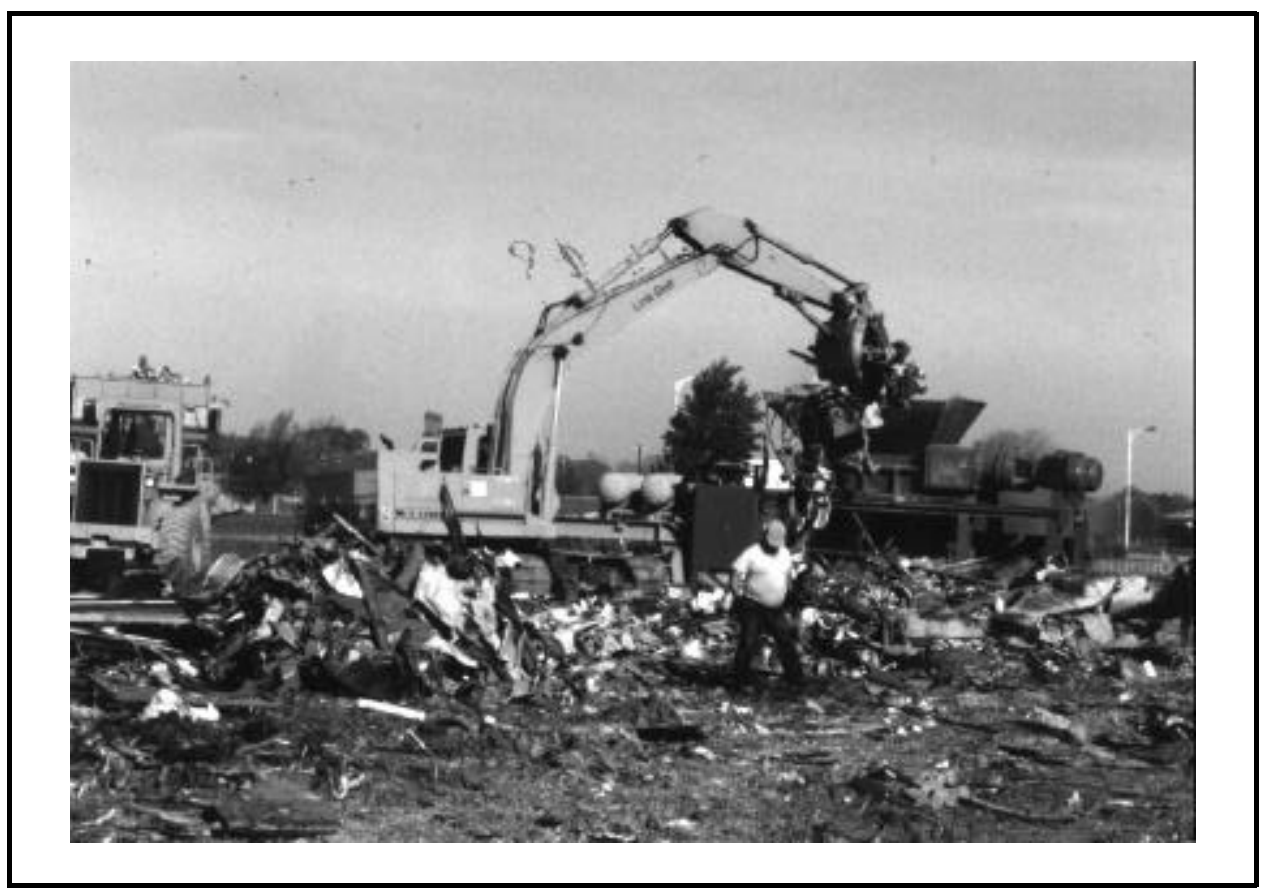

Figure 12. Demolition debris being loaded into debris compactor.

The equipment used for crushing $c \& d$ waste is, typically, some type of loading or conveyance equipment, such as a bucket loader or a claw grappler or conveyor belt, and a crusher. Figure 12 shows demolition waste material being fed into a debris compactor.

Theequipment used to shred C\&D wasteindudes conveyance machinery, collection systems, and a shredder, tub grinder, or hammermill. If the waste is mixed, there may also be some sort of separation system to prevent ferrous scrap or hard materials from jamming the shredder. A shredder either uses rotary hammers or revolving cutting edges to break apart the waste into smaller particles. Shredding is used to reduce the size of dry $C \& D$ waste materials such as wood.

Chippers and grinders are similar to shredders in that the material is reduced to smaller particles. The chipper and grinders typically use rotary devices such as wheels, as opposed to hammermills, to reduce the size of the waste. The materials best suited for processing with a grinder are rubble types of materials, such as masonry or concrete.

A pulverizer grinds or crushes materials into small pieces. A pulverizer uses mills, such as hammermills, to pummel the waste into the requisite size particles. Although any dry waste may be processed with a pulverizer, its primary use is for concrete and rubble. 
Processing some materials may require the combination of several different types of processing technologies. Asphalt processing, for example, may require a grinder to first reduce the size of large pieces of broken asphalt. After the initial grinding, the asphalt may be milled again, with a plug mill, to either reduce the particles to the appropriate size, or mix the asphalt with other materials. There may also be other forms of fixed equipment needed at the materials processing facility, like magnetic separators, screens, classifiers, conveyors, etc.

Despite the advantages of on-site processing, it may be impractical to process materials at the job site due to increased labor, space restrictions, or lack of pick-up services. Commingled $C \& D$ waste must be taken off-site to a material recovery facility (MRF) where it can be separated and recycled if there is a sufficient market. The technology of the equipment will vary from one MRF to another. At one end is the MRF that does not use any type of automatic sorting equipment. The sorting is done by hand, and a bobcat (tractor) is used to move the materials. Or the MRF may have a conveyor belt with a person at each picking station assigned to remove a specific material. Materials separated at this type of facility are usually limited to cardboard, wood, and metals.

Some MRFs use a combination of manual and mechanical sorting techniques to process $C \& D$ waste materials. A grappler may be used to remove oversize items, such as appliances and large pieces of rock, from mixed loads. The remaining material is crushed and fed onto a conveyor with a front end loader where fines and small stones and larger aggregate are removed by a vibrating screen. What is left then passes a magnet to remove ferrous metals. Another conveyor directs the material past several picking stations where wood, stone, and metals are separated manually into roll-off containers.

Larger MRF s will use many more mechanical devices to sort incoming waste based on material size, density, or other physical properties. It may also have the technology to process the sorted material into a marketable item at the facility. A flotation separator will separate dirt and rock from wood and a cyclone and dust control system can discharge light materials such as paper and plastic.

Portable recycle crusher plants are also available. They are compact and fit into confined spaces. A typical unit is equipped with a belt feeder, a vibrating screen, a jaw crusher or shredder, discharge conveyors, diesel engine, and hydraulic power. These plants are built to be road legal, and mount on either standard self-loading vehicles or low-bed trailers. 


\section{Criteria for Choosing Processing Equipment}

In the analysis of the required equipment for either on-site or off-site processing, several factors need to be addressed by the installation engineer, project manager, and contractor: (SWANA 1993).

- composition and quantity

- magnetic properties

- $\quad$ physical size of input material

- market specifications of the potential users

- $\quad$ average density and expected variance. 


\section{Project Evaluation}

The ultimate product of today's construction industry is a structure designed and constructed without any consideration for dismantling and reuse at the end of its life cycle (Gordon and Huddart 1997). The construction industry must consider ways of reducing the impact of building materials on the earth's resources. Directives for recycling and reuse at the outset of a project will encourage the construction industry to rethink the use of processes and materials on the demolition project and to innovate to meet the challenges of sustainable development. A project must be evaluated in terms of how it will benefit the community both economically and environmentally.

Before theindustrial revolution, used building materials were valued because they conserved the great deal of human effort required to produce and install virgin materials. Building materials were routinely cycled from one structure to another. With the mechanization of building material production, installation, and demolition, the industry standard changed from systematic "de-construction" to mechanized demolition (Gordon and Huddart 1997).

From a disposal perspective, $C \& D$ waste requires a high level of energy to recycle, which is why most of it ends up in landfills. Dismantlement of a building is extremely labor intensive compared to mechanized demolition. Technological advances have resulted in the cost of labor overtaking the cost of machines and fuel. As a result, the value of waste materials fell in relation to the low cost of producing and installing new materials.

\section{Economics of Recovery}

To make a case for $C \& D$ recovery, it is necessary to examine the cost and benefits associated with job-site recovery. Table 8 lists the types of costs and financial benefits associated with $C \& D$ waste disposal, as well as those associated with recovery (O'Brien and Allen 1996). Several indirect costs and benefits are included in thetable. Although bottom-lineaccounting does not take theseindirect costs into account, it is important to consider them when setting up and operating a job-site recovery program. Actual costs will vary due to a variety of factors: 
Table 8Costs and benefits of disposal and recovery.

DISPOSAL
\begin{tabular}{|l|l|}
\hline Direct Costs & Indirect Costs \\
\hline Labor & Stress on limited natural resources \\
Equipment & Loss of embodied energy \\
Tipping fees & Environmental impact of extraction and manufacturing operation \\
Taxes and fees & Loss of higher use of land to landfill \\
Financial value of lost & Long-term cleanup costs of landfill \\
material & \\
\hline
\end{tabular}

\section{Benefits}

Convenient

No training needed

No cost to implement a new program

\section{RECOVERY}

\begin{tabular}{|l|l|l|}
\hline Operation Costs & Set-up Costs & Indirect Costs \\
\hline Labor & Labor & Environmental impact of processing and \\
Equipment rental & Equipment purchase & manufacturing operations \\
Equipment repair & Training materials & \\
Recycling/tipping fees & Incentives & \\
Transportation & Evaluation/waste & \\
& analysis & \\
\hline
\end{tabular}

\begin{tabular}{|l|l|}
\hline Direct Benefits & Indirect Benefits \\
\hline Reduced disposal costs & Increased feedstock for remanufacturing \\
Rebates for recovered materials & Increased employment opportunities in remanufacturing \\
Reduced costs for reused materials & Reduced extraction of raw materials \\
Reduced safety claims & Retention of embodied energy \\
Marketing advantage & Extension of natural resource base \\
& Reduced development costs of new landfill/disposal, \\
& which leads to higher tipping fees \\
\hline
\end{tabular}

${ }^{\star}$ Source: O’Brien \& Company, 1996

- $\quad$ Sizeand type of construction. Construction size and type will affect how much and what types of materials are generated, and also when greater volumes of a given material will be generated ("peak generation").

- $\quad$ Space constraints. Space restrictions will affect aspects of the system used to collect recyclable materials on site, such as the size and types of containers, and the equipment used to handle the materials. They may also affect the ability to apply waste reduction techniques, such as setting up a central location for cutting materials.

- Recycling equipment capability. Thetype of equipment availabletothe project for materials handling and collection can affect the ability to recover materials 
on site. For example, if cranable containers are available, they are useful in multi-level projects.

- $\quad$ Recycling services availability. The type of cost-effective recycling services available at the job site will affect the types of materials that can be recovered. This should befactored into identifying materials to betargeted for recycling on the project.

- $\quad$ J ob scheduling (including phasing). An extremely fast-paced job can put severe limitations on the amount of materials recovered for reuse or recycling, since many activities will be happening simultaneously and site recovery efforts may be placed on the back burner. Careful planning, however, can help minimize this problem. With a slow job, the problem can be the inability to collect enough of certain materials in a given period of time to make materials recovery cost effective. If materials can be stored on site without causing safety or space constraints, then this will not be a problem.

- Fees and rebates. When looking at specific materials, it is important to consider the cost to dump versus the cost to reuse or recycle. This would require looking at disposal and recycling fees, taxes, and rebates.

- $\quad$ Field personnel's previous experience with waste reduction. Expect a learning curve when dealing with field personnel inexperienced with waste reduction and recycling practices. This should be factored into setting a percentage goal for waste reduction. It is better to exceed goals than to miss them.

- $\quad$ Other Issues. If the site is urban, the city may charge contractors a special fee for sorting containers located on the city sidewalk. Or, if the site is a commercial remodel in an operating mall, there are likely to be limitations (time, space) regarding materials collection and storage.

\section{Environmental Matrix}

Defense Construction Canada (DCC), a Canadian Government Crown Corporation, has developed a process called "Best Value Tendering" to achieve the best value, defined in terms of energy conservation and waste minimization, when a building is decommissioned. DCC structured contract tender documents to include the diversion of waste from landfills. Contractors are encouraged to devise innovative approaches to achieving high rates of landfill diversion within the bid process. A matrix based on environmental criteria as well as price, is used as an evaluation 
tool (Table 9). A scoring table (Table 10) is then used to convert percentile criteria to ordinal scores (Gordon and Huddart 1997).

Tender submissions were evaluated for the following attributes:

- $\quad$ proposed degree of $C \& D$ waste reuse and recycling

- $\quad$ proposed system of staffing, managing, and executing the project

- detail, sophistication, and technical adequacy of the waste management plan

- bid price.

Table 9E valuation matrix.

\begin{tabular}{|l|l|}
\hline Evaluation Category & Score \\
\hline Percent reuse and percent recycling** & Varies from 0 to 25 as per scoring table \\
\hline Project management and methodology & Varies from 0 to 5 \\
\hline Waste management system & Varies from 0 to 10 \\
\hline Price & Varies from 0 to 60 as per scoring table \\
\hline Total & $/ 100$ \\
\hline${ }^{*}$ Source: Gordon and Huddart (1997). \\
**A minimum aggregate percentage of 90 percent is required by DCC \\
\hline
\end{tabular}

Table 10Scores for reuse, recycling, and price.

\begin{tabular}{|c|c|c|c|c|c|}
\hline $\begin{array}{c}\text { Reuse } \\
(\%)\end{array}$ & $\begin{array}{c}\text { Reuse } \\
\text { Score }\end{array}$ & $\begin{array}{c}\text { Recycle } \\
(\%)\end{array}$ & $\begin{array}{c}\text { Recycle } \\
\text { Score }\end{array}$ & $\begin{array}{c}\text { Price \% above } \\
\text { Low Bid** }\end{array}$ & $\begin{array}{c}\text { Price } \\
\text { Score }\end{array}$ \\
\hline 100 & 25 & 100 & 10 & 1 & 59 \\
\hline 90 & 22 & 90 & 9 & 2 & 57 \\
\hline 80 & 18 & 80 & 8 & 4 & 55 \\
\hline 70 & 15 & 70 & 7 & 5 & 53 \\
\hline 60 & 13 & 60 & 6 & 6 & 48 \\
\hline 50 & 10 & 50 & 5 & 7 & 45 \\
\hline 40 & 8 & 40 & 4 & 8 & 42 \\
\hline 30 & 5 & 30 & 3 & 9 & 39 \\
\hline 20 & 3 & 20 & 2 & 10 & 35 \\
\hline 10 & 2 & 10 & 1 & 0 & 0 \\
\hline 0
\end{tabular}


The contract is awarded to the bidder with the highest total score in the above categories in accordance with the grading criteria. The bid review process uses a two-envelope bid submission system so that technical proposals are evaluated separately from pricesubmissions. Technical envel opes are opened first, evaluated, and either accepted for further review or rejected. Scores of 25 out of 40 are required on technical submissions before the bid advances to the price evaluation stage.

\section{Fort Ord Pilot Project}

A pilot project to dismantle wooden barracks on the former F ort Ord Army Base in Santa Clara, CA began in May 1997. University of California Extension, Santa Cruz, Business Environmental Assistance Center (BEAC) and Fort Ord Reuse Authority (FORA) are working together on the project to determine whether deconstruction is viable alternative to mechanical demolition. The estimates for removal have been as high as $\$ 120$ million. This project should demonstrate ways to offset many of these costs and benefit the community both economically and environmentally.

This project will also provide training and educational materials for reuse and recyding to others across the nation. The goals for this project include (UCSC 1997):

- to collect critical data about deconstruction of representative buildings, including: labor needed; quality and quantity of materials; actual resal evalue of the materials; pre and post-soil, lead, and asbestos testing; costs for deconstruction, and impact on regional landfills-both quantities and savings of diverted materials plus the cost of disposal residue

- to train local contractors and workers from the demolition and recyding, and construction industries in deconstruction techniques, material preparation, types and quality of woods, and associated job-site health and safety procedures

- $\quad$ providematerials for a national materials testing program that will contribute to the devel opment of engineering and use standards for used lumber and associated building materials

- to create training videos using former F ort Ord as a living laboratory of actual work to use for training locally and across the nation

- to host a design charrette and design contest in relation to adaptive reuse, remodeling, and creation of new architectural projects and products. 
The high labor costs of dismantling a building have always made mechanical demolition appear morecost-effective. However, such assessmentsignoretheresale value of the materials and the related environmental benefits. The materials from the deconstruction are stored on-site and sold by silent auction. In this project, up to eight buildings will be dismantled to determine what might be recovered to cut the costs of redevelopment and keep tons of debris out of landfills. 


\section{Conclusions and Recommendations}

\section{Conclusions}

This study has developed concepts for the reutilization of construction materials, induding waste debris, by means of recycling into other components that are useful in construction. Primary opportunities identified in this study to divert $C \& D$ debris from the solid waste stream exist in the form of demolition operations to salvage or recycle building materials and systems. Primary constraints on these operations are the inconsistent nature of $C \& D$ debris, the effort and equipment it takes to evaluateand separatethe materials, the lack of or distance from recycling facilities, fluctuations in the marketplace for recycled materials, and environmental regulations governing certain types of recyclable materials (Ch 2, p 12).

Early in the demolition project, the most appropriate means to divert $C \& D$ debris from the solid waste stream must be determined. The waste stream must be characterized and quantified, and markets for the $C \& D$ waste diverted from the wastestream must be identified ( $p p 15,17)$. Manual wrecking methods may result in debris with the highest salvage and reclamation potential, although this method is very labor intensive and generally occurs on small projects ( $p$ 51). Mechanical and explosivedemolition methods typical ly result in very littlesal vageablematerial (p 52). Certain demolition activities are associated with specific kinds of $C \& D$ waste (Table 2, p 1), and different materials require varying degrees of processing to be recycled or salvaged.

Project managers charged with organizinga construction project recycling program must bear in mind that recycling operations require market analysis and a great deal of planning. The variability of recycling economics demands that management preplan the project as much as possible to reduce the likelihood of unforeseen problems from upsetting the project. Although every construction and demolition project will be different, project managers, installation engineers, and contractors should consider:

- the layout of collection area

- collection

- contract issues for disposal, hauling, etc. 
- material separation and/or preprocessing

- $\quad$ handling hazardous waste (Ch 6, p 49).

Denison and Ruston ( 1990) state that there are two myths that hamper the ability to find workable solutions to the solid waste crisis: (1) that one can manage trash without considering its individual components, and (2) that a single method can successfully manage our entire waste stream. These myths are certainly true for the disposal of $C \& D$ waste. In the past, $C \& D$ waste has been seen as strictly a single material to be disposed of in one way. Managing $C \& D$ solid waste in the future will entail systematic evaluation of every constituent material in the $C \& D$ waste stream.

Dispelling the second myth will also have a considerable influence over solid waste management. The plans and suggestions offered here go a long way in reducing the amount of material that would eventually end up in the landfill, but that is not enough. The most effective solid waste management begins with reducing the amount of waste produced at the source. The amount of $C \& D$ waste in landfills is only a symptom; the root of the problem is consumption, and patterns of consumption are ultimately the activities that must be addressed (Gordon and Huddart 1997).

\section{Recommendations}

The role of the Federal government in $C \& D$ waste management is limited. State and local governments will have more impact because they are intimately involved in working with the contractors. Perhaps the most important role of the Federal government is to use its purchasing power to stimulate the markets for reclaimed construction materials. Federal agencies heavily involved in construction (e.g., Army Corps of Engineers, DOT) can specify the use of reclaimed materials and the recycling of wastes created in their projects.

Processing $C \& D$ waste material can be much easier than finding uses for it and selling it. Developing markets for the material, induding allowing it to be used in higher percentages in government-funded projects, would help "jump start" some new markets. However, care must be taken to ensure that standards are not lowered just so that recycled material can qualify for a job.

The construction industry, including contractors, architects, and owners, all have a part to play in C\&D waste reduction. Cosper, Hallenbeck, and Brenniman (1993) 
have made some recommendations on how the private sector can become involved in $C \& D$ waste management practices:

- Design professionals should urge owners to explore the benefits of recycling and make a commitment to the process for their projects.

- Design professionals should specify the following recycling requirements for waste materials generated on a project:

- Prequalified recycling firms should be named in the specification.

- Reusuable demolition materials should be salvaged and incorporated into new construction, stored for future use, or moved into the salvage market.

- Nonreusuable demolition materials should be recycled.

- $\quad$ Alternate bids should be used to determine the added cost or savings of the recycling requirements.

- Contractors and subcontractors should vol untarily initiaterecycling programs. The costs or savings of the recycling programs should be included in the bids.

- To stimulate the markets for waste materials, design professionals should select and specify used materials or new products made of recycled materials whenever possible. 


\section{References}

American Society of Civil Engineers [ASCE], Minimum Design Loads for Buildings and Other Structures [ASCE 7-95], (ASCE, 1995) p 137.

Army Regulation [AR] 200-1, Environmental Protection and Enhancement, (Headquarters, Department of the Army [HDQA], Washington, DC, 21 February 1997).

Army Regulation [AR] 415-15, Army Military Construction Program Devel opment and Execution, (Headquarters, Department of the Army [HQDA], Washington, DC, 28 April 1997) p 7-4.

Army Regulation [AR] 420-49, Utility Services, (Headquarters, Department of the Army [HQDA], Washington, DC, 28 April 1997).

Army Regulation [AR] 420-70, Buildings and Structures, (Headquarters, Department of the Army [HQDA], Washington, DC, 29 May 1992) p 16.

Asfahl, C.R., and C.S. J ohnson, "Flow Charting Your Way to HSE Compliance," Occupational Hazards (March 1993), pp 54-56.

Brickner, R., "Overview of C\&D Debris Recycling Plants in the U.S.," C\&D Debris Recycling (J anuary/F ebruary 1997).

Brown, E.R., and C.E. Bassett, "Recycling of Civil Engineering Materials," New Horizons In Construction Materials, Proceedings of the ASCE National Convention (American Society of Civil Engineers, October 26, 1988), p 26.

Code of Federal Regulations (CFR), title 40, part 61, section 140.

Code of Federal Regulations (CFR), title 40, part 243, section 101.

Code of Federal Regulations (CFR), title 40, parts 257 and 258.

Code of Federal Regulations (CFR), title 40, part 261, sections 21, 22, 23, Appendix I.

Cosper, S.D., W.H. Hallenbeck, and G.R. Brenniman, Construction and Demolition Waste: Generation, Regulation, Practices, Processing, and Policies, OSWM-12 (Office of Solid Waste Management, J anuary 1993) p 18.

Demkin, J .A., ed., Environmental Resource Guide (American Institute of Architects[AIA], 1996) $p$ MAT 05410:31. 
Denison, R.A., and J . Ruston, eds., Recycling and Incineration: Evaluating the Choices (Island Press, 1990), p 29.

Department of Defense [DOD] Directive 4160.21-M, Defense Reutilization and Marketing Manual (1991).

Department of Defense [DOD] Directive 4165.60, Real Property Acquisition, Management and Disposal (1987).

Department of Defense [DOD] Directive 36, Disposal/ Demol ition of Excess Structures (5 May 1998).

Donovan, C.T., "Construction and Demolition Waste Processing: N ew Solutions ToAn Old Problem," Resource Recycling, Vol 10, No. 8 (August 1991) p 146.

Donovan, C.T., Recycling Construction and Demolition Waste in Vermont (Vermont Agency of Natural Resources, Department of Environmental Conservation, Solid Waste Management Division, Recycling and Resource Conservation Section, December 1990), p v-10.

Donovan, C.T., "Wood Waste Recovery and Processing," Resource Recycling, Vol 10, No. 3 (March 1991) p 88.

Donovan, C.T., and J .E. Fehrs, Recycling Construction and Demolition Wastein Rhode Island (R.I. Governor's Office of Housing, Energy and Intergovernmental Relations, December 1992), pp v-3.

Executive Order [EO] 13101, Greening the Government Through Waste Prevention, Recycling, and Federal Acquisition, 14 September 1998.

"Federal Highway Report Summarizes Asphalt Pavement-Recycling Practices", Rock Products, vol 99 (J une 1996), p 36.

Fickes, M., “Calculating Recycling Markets," World Wastes (December 1997), p 34-35.

Gidley, J .S., and W.A. Sack, "Environmental Aspects of WasteUtilization I n Construction,"J ournal of Environmental Enginering, vol 100, No. 6 (American Society of Civil Engineers [ASCE], December 1984), pp 1117-1133.

Goddard, J im, Developing a Construction and Demolition Debris Recycling System for Disaster Debris Management (Solid Waste Department, Portland Oregon, J anuary 1994), p 10.

Gordon, M., and M. Huddart, "Construction and Demolition Waste: Best Practices Today and Tomorrow," The Construction Specifier (May 1997), pp 109-117.

Guter, E.P., "Quality Cullet Is Required for Fiberglass, Too," Glass Industry, vol 74 (I anuary 10, 1993), pp 13-16+.

Hoke, J .R. ed., Architectural Graphic Standards (J ohn Wiley \& Sons, Inc., 1988), p 812. 
Hornbostel, C., Construction Materials: Types, Uses, and Applications (J ohn Wiley \& Sons, Inc., 1978), pp 155, 500.

Illinois Department of Commerce and Community Affairs [DCCA], Illinois Construction and Demolition Site Recycling Guidebook (Illinois Department of Commerce and Community Affairs [DCCA], 1997) p 13.

Kibert, C.J ., ed., SustainableConstruction: Proceedings of the First International Conference of ClB TG, November 6-6, 1994 (Center for Construction and Environment, University of Florida, 1994), p 624.

Leishman, D., “Conscientious Disposal,” C\&D Debris Recycling (Spring 1996), p 14+.

Means Assemblies Cost Data 19th Annual Edition (R.S. Means Company, Inc., 1994).

Means Building Construction Cost Data 1994 (R.S. Means Company, Inc., 1994).

Murthy, K.S., and S. Chaterjee, Devel opment of PredictiveCriteria for Demolition and Construction Solid Waste Management, Technical Report N-15/ADA033646 (U.S. Army Construction Engineering Research Laboratory [USACERL], October 1976), pp 2, 74, 86.

Musick, M., "Recycling Gypsum From C\&D Debris," BioCycle, Vol 33, No. 3 (March 1992) p 36.

National Association of Demolition Contractors [NADC], The NADC Reports: Demolition Contractors Manage and Dispose of Waste Responsibly (The National Association of Demolition Contractors [NADC], February 1995), p 9.

O'Brien, K., and D. Allen, "Recovering Construction, Demolition and Landclearing Debris: The Bottom Line," Resource Recycling (J une 1996), pp 36-45.

Pamphlet [PAM] 420-47, Sol id Waste Management (Departments of the Army, Navy and Air Force, J une 1978).

The Solid Waste Association of North America [SWANA], Construction Waste\& Demolition Debris Recycling: A Primer (TheSolid WasteAssociation of N orth America [SWANA], October 1993).

Technical Manual [TM] 5-634, Solid Waste Management (Headquarters, U.S. Army Corps of Engineers [HQUSACE], Washington, DC, May 1990).

Technical Manual [TM] 5-809-1, Structural Design Criteria for Loads (Headquarters, U.S. Army Corps of Engineers [HQUSACE ], Washington, DC, 20 May 1992).

Technical Notes [TN ] 420-47-02, Installation Recycling Guide(U.S. Army Engineering and Housing Support Center [USAEHSC] 1991).

University of California, Santa Cruz [UCSC], Fact Sheet: 1997 Fort Ord Pilot Deconstruction Project (UCSC Extension/Fort Ord Reuse Authority, 1997). 
Walmar, E. and S.L. Baron, "Manual of Structural Design and Engineering Solutions", Prentice-Hill, Inc. (1972), p 2170.

Yost, P. and J . M. Halstead, "A Methodology for Quantifying the Volume of Construction Waste," Waste Management \& Research, Vol. 14 (1996), pp 453-461.

Yost, P., and E. Lund, Residential Construction Waste Management: A Builder's Field Guide (National Association of Home Builders [NAHB], J anuary 1997), p 6. 


\section{Bibliography}

Apotheker, S., "Construction and Demolition Debris - The Invisible Waste Stream," Resource Recycling, vol 9, No. 12 (December 1990).

Apotheker, S., "Managing Construction and Demolition Materials," Resource Recycling, vol 11, No. 8 (August 1992).

Army Regulation (AR) 200-1, Environmental Protection and Enhancement (Headquarters, Departmentof the Army[HQDA], Washington, DC, 21 F ebruary 1997).

Boone, K., "Recovering White Goods From the Waste Stream," Resource Recycling, vol 11, No. 8 (August 1992).

Brickner, R.H., "Construction Waste \& Demolition Debris ... Problem or Opportunity?", Demolition Age (October 1992).

Brickner, R.H., "Construction Waste \& Demolition Debris ... Problem or Opportunity Part II: Getting Started," Demolition Age (November 1992).

Brickner, R.H., "Construction Waste \& Demolition Debris ... Problem or Opportunity Part III C\&D Recycling Alternatives," Demolition Age (December 1992).

Clifton, J .R., P.W. Brown, and G. Frohnsdorff, "Uses of Waste Materials and By-Products in Construction, Part II," Resource Recovery and Conservation, vol 5 (1980).

Cosper, S.D., W.H. Hallenbeck, and G.R. Brenniman, Construction and Demolition Waste: Generation, Regulation, Practices, Processing, and Policies, OSWM-12 (Office of Solid Waste Management, J anuary 1993).

Curro, J .P., "An Inside View of C\&D Recycling," BioCycle, vol 32, No. 3 (March 1991).

Cushing, R., "Construction and Demolition Waste Targeted," California County (November/December 1995).

Department of Defense [DOD] Directive 4165.60, Real Property Acquisition, Management and Disposal (1987).

Donovan, C.T., "Construction and Demolition WasteProcessing: New Solutions to an Old Problem," Resource Recycling, vol 10, No. 8 (August 1991). 
Donovan, C.T., “Wood Waste Recovery and Processing," Resource Recycling, vol 10, No. 3 (March 1991).

Gavilan, R.M., and L.E. Bernold, "Source Evaluation of Solid Waste in Building Construction," J ournal of Construction Engineering and Management, vol 120, No. 3 (September 1994).

Geiger, G., "Advances in Glass Processing," American Ceramic Society Bulletin, vol 72 (February 1993).

Gubbels, D., and E. O'Meara, "An Overview of Post-Consumer Wood Waste Recovery Options," Resource Recycling, vol 11, No. 4 (April 1992).

“I nitiating Change in C\&D Management," BioCycle, vol 37, No. 1 (J anuary 1996).

Kalin, Z., “Canada Targets C\&D Debris,” BioCycle, vol 32, No. 1 (J anuary 1991).

L.A. Network, Wood You Recycle? A Guideto Wood WasteReuseand Recycling in the L.A. Area (City of Los Angeles, Board of Public Works, Integrated Solid Waste Management Office, March 1993).

Lohmann, W., "Specifications: Recycling Construction Waste,"ProgressiveArchitecture (May 1991).

Malin, N., "What's New in Construction Waste Management?", ResourceRecycling (February 1996).

Musick, M., "Recycling Gypsum From C\&D Debris," BioCycle, vol 33, No. 3 (March 1992).

NAHB Research Center, Builders Guideto Residential Construction WasteManagement, Project No.: 4129 (National Association of Home Builders [NAHB], March 1993).

Ontario Construction and Demolition Waste Reduction Strategy Team, Keeping C\&D Materials Out of Landfills: Conserving Resources and Minimizing Waste in the Construction Industry (Queen's Printer for Ontario, 1993).

Pieper, P., “Wood Waste Alchemy," BioCycle, vol 34, No. 8 (August 1993).

Steuteville, R., “Big Diversion From C\&D Debris," BioCycle, vol 36, No. 9 (September 1995).

Steuteville, R., "Recycling Debris F rom Construction Projects," BioCycle, vol 33, No. 8 (August 1992).

Steuteville, R., "Whittling Away at Wood Waste," BioCycle, vol 34, No. 1 (J anuary 1993).

“Tree Trimmers Seek Recycling Options," BioCycle, vol 34, No. 2 (February 1993).

Vandall, J ., “Recycling Your Buildings: It's Possible, and It's Preferable," P\&R (J anuary 1995). 
Waller, H.F., and R.W. May, "WasteMaterials in Pavements," ASTM Standardization News (August 1993).

Wilson, A., "Dealing with Construction Waste: Innovative Solutions for a Tough Problem," Environmental Building News: A Bimonthly Newsletter on Environmentally Sustainable Design and Construction, vol 1, No. 3 (November/December 1992).

Witten, M., "Reuse of Low-End Construction and Demolition Debris," ResourceRecycling, vol 11, No. 4 (April 1992). 


\section{Appendix A: Catalog of Recyclable Building Materials}

\section{Background}

The catal og of recyclable building materials indudes the following information (as available) for each of the classifications of waste:

- characteristics of each material category

- $\quad$ quantitative predictive criteria for materials per building type

- $\quad$ salvage potential, including existing end-markets;

- $\quad$ recycling potential, including existing end-markets;

- material removal techniques that maximize recyclability, including any health and safety issues

- debris handling, including processing methods and techniques that, if costeffective, will increase the value of post construction and demolition materials

A review of the waste stream generated at $C \& D$ projects reveals that the composition of waste varies with every project. Although a definitive database of detailed waste composition studies is not known to exist for $C \& D$ waste, the composition will ultimately depend on such factors as: the type and size of the structure; geographic location and local building requirements; the current overall schedule of the project; daily activity being performed; materials used in construction; and demolition practices (SWANA 1993). Construction waste also differs from demolition waste. Demolition debris is more likely to contribute materials contaminated by undesirable components and/or toxic compounds, such as lead paints, varnishes, creosote, and adhesives. Furthermore, materials removed from a demolition site are more apt to be a conglomeration of materials making it more difficult to separate the waste into recyclable building materials.

Accurately predicting thequantity of individual wastematerials froma construction or demolition project is problematic, in the least. For some materials, such as concrete, the project team may be able to reasonably determine the total volume of reinforced concrete that is in building, based on a survey of the total volume of individual components of the concrete frame, i.e., the columns, floor slabs, and 
foundation. It is not certain, however that this will be the total amount to be sent to a recyding facility. Factors such as the method of demolition and the method of collection will greatly influence the amount of material gathered at a site.

Also, accurately measuring the amount of material can be a problem. Some materials are not readily available for measurement, or are difficult to measure. In many cases, the ceiling, walls, or floors must be opened to identify the types and amount of materials. In any case, this should not be providea major difficulty since the building in question or part of the building has already been chosen for demolition. For some materials, it may be too difficult to approximate the quantities by inspection. In these cases, the best source of information may be the original blueprints or "as-built" drawings for the building.

Once the quantity of each material class has been estimated, the next step is to transform this information intoeither weight or volumeestimates. Somereferences are available to assist the project team specifically determine the quantity of each category of materials. The American Society of Civil Engineers' Minimum Design Loads for Buildings and Other Structures (ASCE 7-95), for example, lists the minimum design loads, or "dead loads," for different building materials and systems. Army Technical Manual 5-809-1, Structural Design Criteria for Loads, also lists the design dead loads for various materials and systems. Another source for dead loads and system weights for various building assemblies is Means Assemblies Cost Data.

The potential for salvaging and recycling $C \& D$ waste exists for almost every type of material. Once the waste materials are recovered from $C \& D$ waste, they can then be processed into new building materials or salvaged and reused. Markets exist for recovered materials. The following list contains several resources that for locating these markets as well as providing a guide to where recycled-content building materials can be purchased. Your state and local community may have additional resources that can be helpful in reducing the amount of $C \& D$ waste that ends up landfills.

BioCycle

Monthly magazine

419 State Avenue

Emmaus, PA 18049

Phone: (610) 967-4135

Fax: (610) 967-1345

$C \& D$ Debris Recycling

Monthly magazine

An Intertec/K -III Publication

29 North Wacker Drive
Chicago, IL 60606

Phone: (312) 726-2802

Fax: (312) 726-2574 
Construction Products Containing Recovered Materials

Lists manufacturers and supplierstofacilitate the implementation of the USEPA's ComprehensiveProcurement Guideline(CPG) U.S. Environmental Protection Agency National Center for Environmental Publications and I nformation (NCEPI)

P.O. Box 42419

Cincinnati, OH 45242-2419

Phone: (800) 490-9198

Fax: (513) 489-8695

http://www.epa.gov

Cost-E ffective Home Building

A handbook compiling material-saving methods of efficient design and construction.

NAHB Research Center, Inc.

400 Prince George's Boulevard

Upper Marlboro, MD 20774

Phone: (800) 638-8556

http://www.nahb.com

Directory of Recycled Content Building and Construction Products (Report No, D-95-2)

An offshoot to the Center's Recycled Product Directory (Report No. D-95-1) that features over 400 products for use by business and government agencies. Between the two directories, nearly 1000 recycled content products are listed.

Clean Washington Center

2001 Sixth Avenue, Suite 2700

Seattle, WA 98121

Phone: (206) 587-5520

http://www.cwc.org

The Eco Building Times

Quarterly journal

Phone: (206) 782-3775

EcoDesign

Quarterly magazine

Phone: (604) 738-9334

ENDFIELD

EcoDesign
Quarterly Magazine

Phone: (604) 738-9334

E co-Living Sourcebook

Directory of recycled-content building materials.

110 Linden Street

Oakland, CA 94607

Phone: (510) 452-0500

Enviro

Monthly magazine

Phone: (800) 600-4445

Environmental Building News

A bimonthly newsletter on environmentally sustainable design and construction.

RR1, Box 161

Brattleboro, VT 05301

Phone: (802) 257-7300

Fax: (802) 257-7304

E-mail: EBN@Sover.net

http://www.ebuild.com

The Environmental Home Database

Provides product information to help you make appropriate design choices for commercial and residential renovation projects.

LCRA

P.O. Box 220 5-300

Austin, TX 78767-0220

Attn: Marcia P. Roberts, AI A

Phone: (800) 776-5272 ext. 7626

Fax: (512) 473-4097

E-mail: marcia.roberts@cra.org

http://www.Icra.org

Guideto ResourceEfficient Building Elements A detailed listing of companies that manufacture resource-efficient building materials.

Center for Resourceful Building Technology (CRBT)

P.O. Box 100

Missoula, MT 59806

Phone: (406) 549-7678 
Fax: (406) 549-4100

Web page: www.montana.com/crbt/

Environmental Resource Guide

A collection of detailed material assessments, articles, and case studies connecting environmental awareness with building construction.

American Institute of Architects (AIA)

9 J ay Gould Court

P.O. Box 753

Waldorf, MD 20604

Phone: (800) 365-ARCH

Fax: (800) 678-7102

Global Recycling Network (GRN)

A web site that features information on recycled products and offers a place for manufacturers and distributors to sell their products.

2715A Montauk Highway

Brookhaven, NY 11719

Fax: (516) 286-5551

E-mail: grn@grn.com

http://www.grn.com

GreenClips

Biweekly news on sustainable building design and related government and business issues.

Phone: (415) 928-7941

E-Mail: GreenClips@aol.com

http://solstice.crest.org/envi ronment/greencli ps/

Green Spec

Guideline specifications for environmentally considered building materials and construction methods offers considerations and suggestions for specifying materials in CSI Divisions 1 through 9.

Alameda County Waste Management

Authority

777 Davis Street, Suite 200

San Leandro, CA 94577

Phone: (510) 614-1699
The Harris Directory

A database of recycled content building materials.

B.J. Harris

508 J ose St. \#913

Santa Fe, MN 87501

Phone: (505) 995-0337

Fax: (505) 820-1911

E-mail: bjharris@igc.apc.org

J ournal of Light Construction

Monthly magazine

P.O. Box 686

Holmes, PA 19043

Phone: (800) 375-59811

McRecycle USA Program

Region-specific database available on recycled content building materials.

McDonald's Corporation Environmental

Affairs

Kroc Drive

Oak Brook, IL 60521

Phone: (800) 220-3809

\section{National Park Service Database}

A database of over 700 environmentallyresponsible building materials and includes a listing of 2,000 North American companies that recycle construction waste.

Attn: Sally Small

P.O. Box 25287

Denver, CO 80225

Phone: (303) 969-2466

E-mail: sally_small@nps.gov

National Wood Recycling Directory

A reference book listing products made from recycled wood, examples of products that can be recycled, contact information, and nationwide listing of wood residue receiving centers.

American Forest \& Paper Association (AF\&PA)

1111 19th Street, NW, Suite 800

Washington, DC, 20036 
Official Recycled Products Guide (RPG)

Directories listing companies specializing in materials recycling markets, equipment and special services.

American Recycling Markets, Inc.

P.O. Box 577

Ogdensburg, NY 13669

Phone: (800) 267-0707

Fax: (315) 471-3258

Recyclables Exchange

The Chicago Board of Trade (СBOT)

Dedicated to the international trade of recyclables by facilitating contact between buyers and sellers. Users register online and can tradefor a $\$ 10$ one-time fee and a nominal charge for listings on a pay-as-you-go basis. Sellers post product listings and buyers enter requests for commodities.

http://cbot-recycle.com/indexst.html

Recycle Net

Web site with recycling associations, publications,

equipment and recycler's exchange. http://www.recycle.net

P.O. Box 24017

Guel ph, Ontario

Canada N1E 6V8

Phone: (519) 767-2913

Recycled Products Guide

Federal Supply Service

U.S. General Services Administration

Centralized Mailing List

P.O. Box 6477

Mailing code RCPG-0001

Fort Worth, TX 76115

Recycling Times

Bi-weekly journal

4301 Connecticut Ave., N.W. \#300

Washington, DC 20008

Phone: (800) 829-5443

Recycling Today

Monthly magazine 
4012 Bridge Ave.

Cleveland, $\mathrm{OH} 44113$

Phone: (800) 456-0707 (216) 961-4130

Fax: (216) 961-0364

Resources for Environmental Design Index Guide

Provides useful information on green building products and materials along with techniques for sustainable design and construction.

Iris Communications, Inc.

P.O. Box 5920

Eugene, OR 97405-0911

Phone: (800) 346-0104

Fax: (503) 484-1645

http://www.oikos.com

Resource Recycling

Monthly magazine

P.O. Box 10540

Portland, OR 97296-0540

Phone: (503)-227-1319

Fax: (503) 227-6135

E-Mail: rerecycle@aol.com

Sustainable Building Sourcebook

Available in electronic format on the Web.

City of Austin Green Builder Program

http://www.greenbuilder.com/sourcebook

Waste Age

Monthly magazine

4301 Connecticut Ave., N.W. \#300

Washington, DC 20008

Phone: (800) 829-5411 (202) 244-4700

Wastespec

Provides model specifications for construction waste reduction, reuse and recycling.

Triangle J Council of Governments

P.O. Box 12276

Research Triangle Park, NC 27709

Phone: (919) 549-0551
World Wastes

Monthly magazine

Fulfillment Department

P.O. Box 41369

Nashville, TN 37204-1094

Phone: (800) 556-2209 


\section{Asphalt}

\section{Characteristics}

Asphalt is a cementitious material consisting of either naturally occurring bitumens or those derived from petroleum distillation. Construction applications of asphalt include: pavement for roads, bridges, parking lots, roofing, and resilient flooring.

Asphalt Paving. Hot or cold pavement includes: asphalt, fine and coarse aggregates. The subbase consists of compacted fine and coarse aggregates. Heavy duty applications may include roadway construction and drainage systems. All mixes of asphalt paving generally contain only 5 percent of pure asphalt, the rest being aggregate material. Asphalt paving is typically constructed as a continuous surface, but it may also be found in the form of blocks and tiles.

Roofing Materials. Asphalt-based roofing materials typically contain asphalt and felt, stabilizers particles (silica, marble, sandstone, etc.), and colored granules. Asphalt shingles typically contain 25 to 40 percent pure asphalt depending on the fibers used and the age of manufacture (Donovan 1991). If it is built-up roofing, materials may al so include gravel, crushed stone, etc., for ballast. The methods of fastening for most roofing systems are usually mechanical (nails, generally) or cementitious adhesive.

Flooring. Resilient asphalt flooring contains asphaltic binder, fibers (including, prior to 1971, asbestos), inert filler materials, and color pigments. Asphalt was, at one time, used for extruded shapes, such as cove bases. Flooring is usually installed on wood subfloor system (plywood or fiberboard, lumber, etc.) in residential applications. The fastening system is usually adhesive.

\section{Quantity Estimates}

Most asphaltic products are sheet or paving materials, therefore, the best way to estimate the quantity of expected waste is by measuring the area. Once this has been calculated, the quantity must be converted to its weight, in tons, by multiplying this area by the ASCE 7- 95 figure. It is important to determine the number of layers (or plies) of asphalt. If the roof is asphalt shingles, the total area of the roof must be multiplied by the number of layers of shingles to determine the total area of shingles. For example, a wood frame barracks has the layers of asphalt shingles. The total area of the roof is $1400 \mathrm{sq} \mathrm{ft}$. The ASCE 7-95 dead load figure is $2 \mathrm{lb} / \mathrm{square}$ foot (ASCE 1995). Therefore, the total weight of the asphalt shingles is $8400 \mathrm{lb}$ or 4.2 tons. 
3 layers $\times 1400 \mathrm{sq} f \mathrm{ft} \times 2 \mathrm{lb} / \mathrm{sq} \mathrm{ft}=8400 \mathrm{lb}$

If the roof is built-up, multi-ply type asphalt felt, the number of plies determines the weight per square foot.

5 -ply roofing $=6.5 \mathrm{lb} / \mathrm{sf}$

\section{Salvage Potential}

The potential to salvage most asphalt building products is very low. The two largest categories of asphaltic materials, roofing materials, and paving, cannot be reused directly without substantial processing.

\section{Recycling Potential}

The potential to recycle asphaltic materials is high considering the fact that technology and the markets for recycled asphalt is in place in most areas of the country. This is primarily due to the reuse of asphalt for recycled asphalt paving (RAP). There are some drawbacks to the use of recycled asphalt waste materials. The disadvantage to using reclaimed asphalt paving or roofing materials for RAP is that it may be difficult to characterize the redaimed aggregate since its difficult to maintain consistent quality control, moisture may be higher than acceptable, there is not a consistent standard for reference. There is still not a long term study of performance of RAP in such high use applications as highway topping. Therefore, most RAP is used in noncritical applications as road base, bottom layer of pavement, or driveways and parking areas.

Second, RAP processors may be unwilling to use waste roofing materials because of the high potential for contaminants. Waste roofing may contain fasteners, flashing, adhesive, fiberglass reinforcement, gravel and other aggregate, wood or other roof substrate, asbestos, etc. If the debris contains asbestos there is nothing the processor may do with the stock. Recyclers may also be unwilling to use the stock in fear that it will cause a break down in their machinery.

\section{Material Removal}

Most asphalt roofing materials must be manually removed from structures. The shingles or plies are lifted from the roof decking manually and transported to the collection containers. Asphalt paving materials aregenerally removed mechanically in two ways: (1) by breaking it in place and then loading into a collection vehicle or (2) by the special-use surface grinding machines. 


\section{Debris Handling}

Both categories of asphalt products, roofing and paving, require different methods of handling depending on the final application of the roofing materials. The asphalt-impregnated fibers and aggregate in the roofing felt must be cleanly separated from the roofing substrate. In the case of asphalt roof shingles, this is not a difficult since the shingles are typically mechanically attached to the substrate with nails or other fasteners. The shingles are just pried up and pulled from the roof.

Asphalt-impregnated composition roofing is more difficult toremove. Typically, the adhesion between the asphalt and the substrate is relatively tough. The roofing materials must be removed mechanically with scoops, but this is rarely done since the plies are difficult to separate. In the normal course of a building's life, the roof is maintained by adhering more layers to the existing roof.

Asphalt paving materials are generally removed mechanically by breaking the asphalt into small pieces. The pieces are then loaded into a truck and hauled to a processing area. Many municipalities use equipment that removes the asphalt pavement, or a layer of it, mixes it with new asphalt and aggregate, and relays it in one continuous operation.

If the debris is to be used for RAP, the steps to process the debris include: transporting the waste asphalt materials to a central processing facility, crushing or shredding the debris, separating the asphalt and mineral aggregate from contaminants such as metal or wood, and mixing with either new aggregate, other reclaimed asphalt materials, or virgin asphalt emulsion. Donovan (1990) describes a representative recycled asphalt paving processing plant (see Figure A1). 


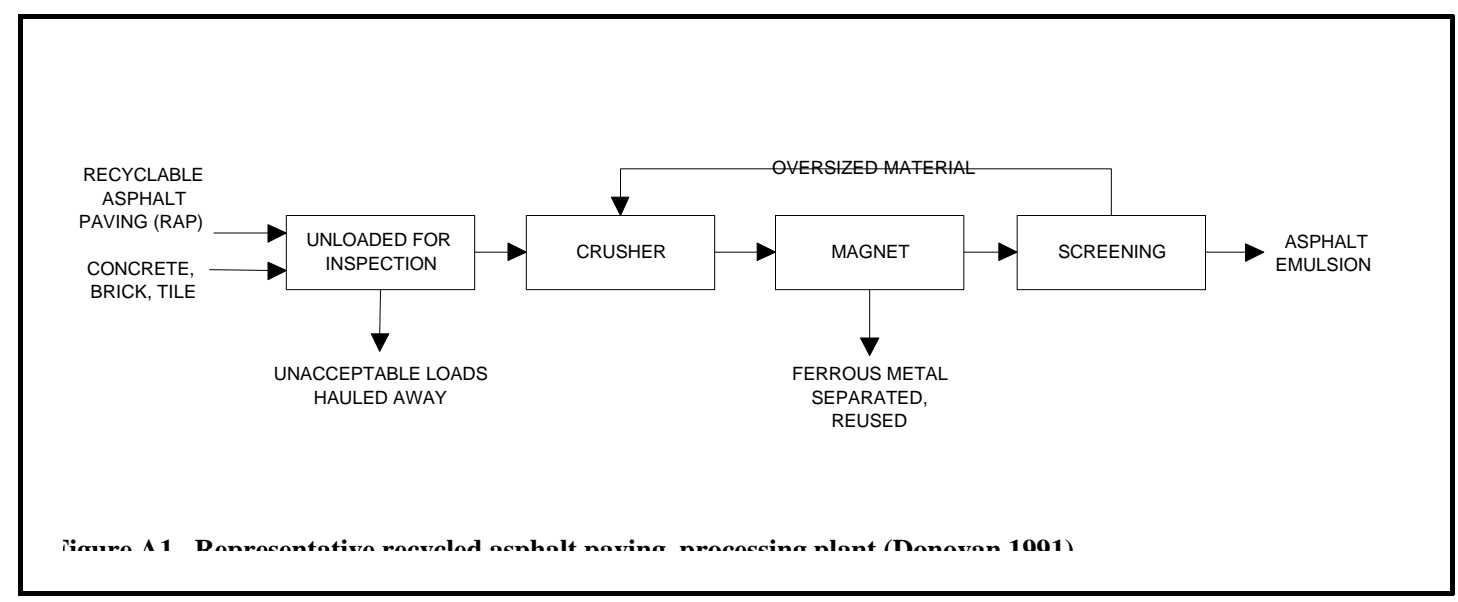

Figure A1. Representative recycling asphalt paving processing plant.

\section{Brick}

\section{Characteristics}

The term brick refers to the shape of a small unit of building material. Bricks have been used for centuries in building projects. Bricks are used most commonly as wall materials, either in load-bearing walls or nonload bearing partitions. Concrete and day bricks are often also used as paving materials. It is either a fired clay unit or a cementitious unit that cures by chemical reaction. Sand and lime mixtures can also be used to produce bricks for applications that require high compressive strength or acid and fire resistance.

Clay brick, also known as burned or fired brick, comes in a number of different configurations, colors, and finishes. The clay material is hydrated silicate of alumina and may contain a number of different oxides. Some paving bricks are made of shale. Concrete brick will be covered under concrete masonry. Brick walls, depending on the application, typically contain the brick, mortar (cement, aggregate, and lime), metal ties and reinforcement, metallic flashing, and insulation. Therearethreecategories of brick wastecategories; salvaged ol d bricks, discarded or left over bricks from construction, and crushed masonry walls or partitions. 


\section{Quantity Estimates}

The volume and density of debris from a masonry wall will depend on the type of brick used and the construction of the wall. The weight of individual bricks may range from 2 to $5 \mathrm{Ib}$ each, depending on its composition, density, and size. The most appropriate method to determine the weight of the waste masonry debris is to multiply the square footage of the wall(s) by the design dead load figure in ASCE 7- 95 or Army Technical Manual 5-809-1 for the wall. The dead load is listed by the wythe of the wall. For example, ASCE (1995) lists the load for an 8-in. wythe clay brick wall as $79 \mathrm{lb} / \mathrm{sq} \mathrm{ft}$. If the square footage of brick wall is $1500 \mathrm{sq} \mathrm{ft}$, the total weight of the wall is $118,500 \mathrm{lb}$, or 59.25 tons.

$500 \mathrm{sq} f \mathrm{ft} \times 79 \mathrm{lb} / \mathrm{sq} \mathrm{ft}=118,500 \mathrm{lb}$

The volume of the debris can be cal culated by multiplying the square footage by the width of the wall. The volume of the above wall would be $1500 \mathrm{sq} f \mathrm{ft}$ by $0.66 \mathrm{ft}$ wide (8/12 in. $=0.66 \mathrm{ft})$, or $999.99 \mathrm{cu} \mathrm{ft}$.

For other brick or masonry systems, such as brick paving, the weight of the debris may be computed by multiplying the weight of an individual brick or small section by the total number of bricks in the system.

\section{Salvage Potential}

The potential to salvage old bricks is high in many areas of the country. Markets have existed for used brick throughout the country, particularly in the Midwest and Northeast. This is because many buildings pre-date World War I. Most masonry building prior to the WWI used mortar that was predominantly cement and lime. Masonry walls using this type of mortar will generally allow the brick to be separated with very little effort. Masonry walls or pavement aretorn down and the individual bricks can be carefully separated from the mortar and cleaned. The bricks are cleaned either manually with hand tools and solvents, or mechanically with machinery.

Left over or discarded bricks from construction activities, such as fireplace construction, typically make it into the waste stream if the masonry contractor cannot reuse them because of an unusual color or size. These bricks may be returned to the supplier or consolidator. The bricks may also be sold to a landscaping firm to be used for crushed ground cover. 


\section{Recycling Potential}

If it is not economically or practically feasible to separate the salvaged bricks from other materials in the wall or pavement, the next step to consider is recycling them into other useful material. Crushed masonry can be used as aggregate for roadbed, as backfill, or as aggregate for nonstructural concrete. The bricks may also be sold to a landscaping firm to be used for crushed ground cover or ornamental stone.

\section{Material Removal}

The demolition of a masonry wall requires careful planning. Removing part or most of the wall may reduce the structural stability of the wall or surrounding structural system. This can lead to a collapse of the entire structure if the wall is a load bearing.

\section{Debris Handling}

The amount of separation needed to remove the bricks from other materials in the wall system such as mortar, insulation, or metal reinforcement needed will depend on the recycling outlet. For salvaged bricks to be marketable, they must be physically separated from the mortar and other materials of the wall or partition. This must be performed carefully to prevent the individual bricks from breaking. Most salvaged-brick markets require the bricks to be cleaned and palletized. The separation of brick from mortar is labor intensive, which will affect the economics of the salvage operations. Since clay bricks are relatively brittle and weak in tension, there may be a significant amount of breakage during handling and processing. This will lead to a significant amount of residue to be disposed.

If the final market for the masonry is crushed aggregate, then the demolition contractor may use less care in removing themasonry walls and partitions since the next step is to crush the debris into appropriate size granules. For crushed aggregate, the masonry can be crushed using a tub grinder or hammermill. For

salvaged bricks, the most common form of processing is to pry the mortar from the bricks and clean the bricks.

The most significant health and safety issue in the recycling or salvage of bricks is in the demolition or removal of the brick from the wall. The bricks must be removed carefully to prevent the wall from collapsing. The use of mechanical equipment may cause some dust or noise pollution that may also be considered hazardous. 


\section{Building Equipment}

\section{Characteristics}

Building equipment can be split into three areas: installed building equipment, equipment-in-place, and movable equipment. The most significant environmental problem associated with building equipment is if it contains a hazardous substance, such as asbestos or Polychlorinated Biphynels (PCBs). Asbestos is a mineral that was used in fire and chemical resistant products. Both asbestos and PCBs are considered carcinogenic by the USEPA. This category of materials includes such things as installed equipment, machinery, and hardware. Most removable equipment from buildings are reused or discarded under AR 420-70 and Army Technical Mechanical 5-634.

Installed. Installed building equipment is equipment that is "normally provided and installed as part of a building construction contract and funded with Military Construction, Army (MCA) funds," (AR 420-70, Terms). This category includes equipment installed or fabricated as an integral or affixed component of thefacility. Included are cooling, heating, communications, and el ectrical equipment. TableA1 lists examples of installed building equipment from Army Regulation 415-15. If the equipment was manufactured prior to the 1970s there may be some potential that it may contain hazardous materials such as asbestos and PCBs.

Equipment-In-Place. Equipment in place is defined as "personal property consisting of capital property and other equipment of a usable nature that has been fixed in place or attached to real property, but that may be severed or removed from buildings without destroying the usefulness of the building" (AR 420-70). This type of equipment is typically concentrated in commissaries, kitchens, lavatories, laboratories, maintenance, and storage facilities.

Movable. Movable equipment is any operational equipment for which installation mountings and connection are provided in the building design, and that is detachable without damage to the building (AR 415-15, p 7-4). These items are considered personal property rather than real property. A list of typical items is in Table A2. Most of these items are disposed of through the DOD's Defense Reutilization and Marketing Office (DRMO) according to AR 420-70.

Equipment in place and movable equipment are problems for the solid waste industry because of their potential hazards to the environment. Home appliances, 
also known as white goods, are a particular problem because the motors, compressors, etc., sometimes contain PCBs.

\section{Quantity Estimates}

The appropriate manner to estimate the quantity of building equipment is determined by the type of equipment. Supply equipment, such as wiring, piping, or duct work is most likely measured in linear feet to measure the quantity of redaimable material. Individual equipment such as furniture, fixtures, hardware, mechanical equipment, or storage units must be counted as individual items.

Table A1. Installed building equipment.

\begin{tabular}{|c|c|}
\hline $\begin{array}{l}\text { Antennas } \\
\text { Benches (built-in) } \\
\text { Bookcases } \\
\text { Bulletin and chalkboards } \\
\text { Cabinets } \\
\text { Carpet } \\
\text { Chapel seating, pulpits, and communion rail } \\
\text { Closets } \\
\text { Desks and tables (built-in) } \\
\text { Dishwashing equipment } \\
\text { Drinking waste coolers } \\
\text { Electric (electric fixtures and power equipment) } \\
\text { Elevators and elevator doors } \\
\text { Escalators } \\
\text { Exhaust systems } \\
\text { Fire alarm systems } \\
\text { Food service equipment (built-in) } \\
\text { Gas fittings } \\
\text { Generators } \\
\text { Hardware and fixtures for the handicapped } \\
\text { Heating, ventilating, and air conditioning } \\
\text { Hoists (cranes and crane rails) } \\
\text { Incinerators } \\
\text { Intercom system } \\
\text { Jail equipment } \\
\text { Key control systems } \\
\text { Laboratory sinks, tables, and benches } \\
\text { Lockers (built-in) } \\
\text { Meat-cutting equipment }\end{array}$ & $\begin{array}{l}\text { Nurse call system } \\
\text { Paging system } \\
\text { Panel boards } \\
\text { Plumbing } \\
\text { Pneumatic tube systems } \\
\text { Pot and pan washing systems } \\
\text { Protective construction features } \\
\text { Refrigeration equipment } \\
\text { Refrigerators (built-in and walk-in) } \\
\text { Storm sash and doors } \\
\text { Safety signs } \\
\text { Screens } \\
\text { Shelving and racks (built-in) } \\
\text { Signs and marking for boundary, area, building, } \\
\text { room, and unit identification } \\
\text { Sprinklers } \\
\text { Sterilizers (built-in) } \\
\text { Storage bins (built-in) } \\
\text { Telecommunications system } \\
\text { Theater and auditorium railings } \\
\text { Theater stage and fire curtain } \\
\text { Traffic railings } \\
\text { Vaults } \\
\text { Vehicular and pedestrian traffic control and } \\
\text { direction signs } \\
\text { Venetian blinds and window shades } \\
\text { Wardrobes (fixed) } \\
\text { Waste disposers } \\
\text { Other similar nonseverable items }\end{array}$ \\
\hline
\end{tabular}


Table A2. Movable equipment.

AR 415-15 (p. 7-4) defines Movable equipment as follows:

$\$$ Furniture

$\$$ Furnishings, including rugs

$\$ \quad$ Filing cabinets, and portable safes

$\$$ Office machines

$\$$ Wall clocks

\$ Food service equipment

$\$$ Dental chairs and pedestal units

$\$$ Shop equipment

\$ Photographic equipment

\$ Training aids and equipment, including simulators

$\$$ Automated data processing equipment.

If the supply equipment is to be directly reused, the estimate of linear feet should suffice without modification. However, if the project team is trying to determinethe amount of recoverable salvageable metal content, for example, the linear quantity must be converted to weight. This information is covered in the section metals, ferrous and nonferrous.

\section{Salvage Potential}

The salvage potential for certain building equipment is very high due to the availability of second market outlets such as used equipment liquidators and scrap processors in many areas of the country. Items such as furniture, data storage systems, food service equipment, and other movable equipment generally retain a percentage of their value on the second-hand market.

Built-in mechanical equipment may or may not havea high salvage potential if the equipment is in need of repair, is unserviceable, or is relatively inefficient compared to similar new equipment.

\section{Recycling Potential}

The "recycling" of building equipment is defined here as the direct reuse of movable and fixed equipment without substantial reprocessing. For example, the use of kitchen equipment such as tables, fixtures, and appliances is recycling. 


\section{Material Removal}

Salvage stores obtain most of their items when a contractor calls and arranges to have reusable building equipment removed from a demolition or remodeling site. The salvage people go to the site and pick up the items in their truck. The "supplier" of the item will either receive cash on the spot or credit at the salvage store. Care must be taken to remove the equipment to be reused without substantial reprocessing, such as appliances or movable equipment. The economic success of the program will depend on whether the equi pment is re-sal eablewithout costly post-removal repair. A salvage operation such as this requires a large warehouse where the items can bestored and displayed for sale. Nonprofit agencies may also be willing to take building equipment to supply community groups with affordable building materials. The donor of the materials receives a tax deduction in place of an invoice from a disposal company and the materials stay out a landfill.

\section{Debris Handling}

An important consideration in handling equipment is transportation to the market or reprocessor. Additional laborers can be used to remove valuable materials from a building. Care needs to be taken to ensure that the materials are not damaged as they are removed and stored on-site. Materials should be transported to reuse centers or picked up by the reuse centers as soon as they are removed to minimize damage. A second consideration is protecting the health and safety of the removal team. Many buildings built before 1970 may contain asbestos insulation on duct work and piping. There may also be lead-based paint on installed equipment that could become mobile if chipped during removal.

\section{Ceramics/Clay}

\section{Characteristics}

Ceramics are defined as "inorganic, nonmetallic materials or products that have been subjected to heat treatment and are usually serviceable through high temperature processing and use" (Hornbostel 1973, p 155). Ceramic material is used for a great variety of building products including: porcelain fixtures, sewer pipe, terra cotta veneer, floor/wall tile, and structural/fire-resistant brick and pipe. The principal component of ceramic materials is raw clay. Clay consists of fine mineral granules, induding aluminumsilicates. Thereareseveral types of building applications: fixtures, structural tile, pipe, roof tiles, and veneer applications. 
Fixtures. Plumbing fixtures comprise the bulk of use of ceramic/clay material. Porcelain, a refined form of clay that is vitrified to form a hard, water-impermeable surface is a commonly used form of clay for fixtures. Toilets, sinks, and some chemical laboratory equipment are made of porcelain. Although these fixtures are usually not an integral part of a building's structure, they are typically part of the debris from demolition since there is, in most cases, little economic incentive to reuse porcelain plumbing fixtures.

Structural/Masonry Units. Clay structural tiles are used in both load bearing and nonload bearing applications. Load bearing clay tiles are used either in wall construction or as facing tile. These tiles are typically laid up with mortar and reinforcement. Nonload bearing tile comes in the form of back up tile, fireproofing, or decorative screen tile. These also are commonly constructed with mortar and, if applicable, reinforcement. In some cases, structural tiles are faced with ceramic veneer tile or plaster/drywall. Clay floor or roof structural tiles also come under the distinction of structural/masonry units.

Pipe. Drain tiles, vitrified pipe, and flue linings consist of the same type of clay used in fired brick. Drain tiles come in a variety of sizes and shapes and are typically used for below-grade applications. Vitrified pipe is used for sanitary and sewer systems, but also can be used for heating ducts. Rubber gaskets, oakum and cement, and bituminous compounds are used to seal the tile joints. But in many cases, no sealing gasket is used.

Roof Tiles. The clay used for roof tiles is similar to the type used for brick. There is also a variety of styles, shapes, and sizes. The tiles either interlock or are connected to the roof with mechanical fasteners.

Veneer Tiles. Ceramic wall and floor tile are referred to as veneer tile since they are not expected to add to the structural integrity of the support system. They are distinguished by their thinness and glazed finish.

\section{Quantity Estimates}

According to Architectural Graphic Standards (Hoke, ed., 1988), the quantity of structural clay tile can be estimated using the following conversions:

$$
\begin{aligned}
& \text { 4-in. Hollow }=23 \mathrm{lb} / \mathrm{sf} \\
& \text { 6-in. Hollow }=38 \mathrm{lb} / \mathrm{sf} \\
& \text { 8-in. Hollow }=44 \mathrm{lb} / \mathrm{sf}
\end{aligned}
$$


Porcelain plumbing fixtures from kitchens and bathrooms should be counted and listed as individual items to be salvaged.

\section{Salvage Potential}

Ceramic plumbing fixtures can be removed from a building and sold to salvage operations for their resale value. Ceramic tiles left over from a construction job can be saved and reused. However, variations in shades between the different batches of the same tile line may occur.

\section{Recycling Potential}

Ceramics such as porcelain as well as clay tiles and veneer, can becrushed and used for aggregate.

\section{Concrete}

\section{Characteristics}

Concrete is the generic term for a mixture of cement, sand, gravel, and other forms of aggregate and admixtures that cures into a hard, durable material. The mixture of these components influences the concrete's characteristics including strength, consistency, and curing time. Concrete is used in a wide variety of construction applications such as foundation and superstructure construction, retaining walls, floors, walls, roofs, and pavement.

Because of the wide variety of types and uses for concrete, for this report, concrete applications will be categorized as ether:

- $\quad$ Reinforced concrete, including foundation, structural members, slabs, floor and roof decking

- $\quad$ Precast concrete, includes veneer panels for exterior application, pipe, as well as structural units such as precast sections of decking and structural shapes

- $\quad$ Concrete masonry units (CMUs), a block of molded concrete with one or two hollows. The type of aggregate used for CMUs can include sand, stone, gravel, slag, and coal cinders. 


\section{Quantity Estimates}

Estimation of the potential concrete debris volume is, in most cases, not difficult. If the actual volume of the concrete cannot be estimated by directly measuring the walls, floors, or columns of the building's structure, there are several good references that give the quantity of materials for general building uses. One of these references, Means Assemblies Cost Data, published by R.S. Means Company, lists the quantity of material in either volume or density for typical building applications. If, in the case of concrete, the data is listed in volumetric form, this information may be converted to density by multiplying the volume by $145 \mathrm{lb} / \mathrm{cu}$ $\mathrm{ft}$, or 3,915 lb/cu yd of normal weight concrete. F or example, is you know a concrete wall contains $8.5 \mathrm{cu}$ yd of concrete, the weight of this wall is:

\section{$4.5 \mathrm{cu}$ yd $\times 3915 \mathrm{lb} / \mathrm{cu}$ yd $=17,618 \mathrm{lb}$}

Footings. According to Means (1994), a 16-in. wide by 8-in. deep strip footing contains approximately $0.033 \mathrm{cu}$ yd of concrete and $2.5 \mathrm{lb}$ of reinforcing steel per linear foot of footing (Means 1994). A 24-in. wide by 12-in. deep strip footing contains $0.074 \mathrm{cu}$ yd of concrete and $3 \mathrm{lb}$ of reinforcing steel per linear foot of footing. Therefore, the outside perimeter distance should be multiplied by these quantities. For example, the footing for a building with a perimeter measuring 240 $\mathrm{ft}$ would contain approximately $8 \mathrm{cu}$ yd of concrete $(31,320 \mathrm{lb})$ and $600 \mathrm{lb}$ of steel if the footing is $16 \mathrm{in.}$ wide.

A typical spread footing for one or two story residential and commercial building is 3 by 3 -ft in area, and $1 \mathrm{ft}$ thick. This contains approximately $0.33 \mathrm{cu}$ ydof concrete and $12 \mathrm{lb}$ of reinforcing steel. Therefore, a building with three interior load bearing columns, would have three spread footings that amount to approximately $1 \mathrm{cu}$ yd of concrete $(3,915 \mathrm{lb}$ ) and $36 \mathrm{lb}$ of steel. Spread footings for larger buildings depend on the bearing capacity of the soil and the superimposed load on the footing.

Pilings. The amount of concrete in a pile depends on the diameter and length of the pier. If the pier length is not known since it is typically below grade, the length will have to be estimated. A typical pier for a one/two story building may be $10 \mathrm{in}$. square (or round) thick and $6 \mathrm{ft}$ long, with approximately $5 \mathrm{lb} / \mathrm{ft}$ of steel reinforcement. A square pier would therefore contain $0.15 \mathrm{cu}$ yd dof concrete and $30 \mathrm{lb}$ of steel.

Foundation Walls. A cast-in-place concrete wall, $4 \mathrm{ft}$ tall by $10 \mathrm{in}$. thick, contains $0.199 \mathrm{cu}$ yd of concrete and $9.6 \mathrm{lb}$ of reinforcing steel per linear foot of wall (Means 1994). The volume of concrete used in other foundation elements such as grade 
beams, spread footings and piles is highly dependent on the loading condition of the building and the bearing capacity of the soil. Therefore, it is difficult to include an generalized estimate here. The surveyor should estimate the volume of these elements.

Superstructure. Thesuperstructure of a concrete framebuilding includes columns, walls, beams and slabs. Most cast-in-place concrete floor and roof systems include beams and slabs that are cast monolithically, i.e., at the same time, to ensure that they act as a single system. Therefore, once the type of system is identified, an estimation of the quantities can be derived from a configuration listed in Means (1994). There are several types of slab and beam systems, such as one way or two way beam and slab systems, flat plate and waffle slabs. The quantity of concrete can be estimated by determining the quantity in each of the individual elements.

Floor Systems. The easiest method to estimatethe quantity of concretein the floor system of a building is to multiple the total floor area by a proportionate quantity of material. Means Building Construction Cost Data (Means 1994) contains a table of quantities of concreteand reinforcement in a floor system, categorized by thetype of construction, the design liveload, and the span of the construction. For example, the estimated amount of concrete in a one way beam and slab floor system with a design live load of $100 \mathrm{lb} / \mathrm{sq} \mathrm{ft}$ and a 20 - $\mathrm{ft}$ span is $0.54 \mathrm{cu} \mathrm{ft} / \mathrm{sq} \mathrm{ft}$ of floor area. Therefore, a building with a total floor area of $5400 \mathrm{sq} f t$ would contain 2,916 cu ft (or $108 \mathrm{cu}$ yd) of concrete. According to the table, this system would also contain $2.69 \mathrm{lb} / \mathrm{sq} \mathrm{ft}$ of floor area in reinforcement steel. The floor system, therefore, 
contains $14,526 \mathrm{lb}$ of steel. A summary of the most common floor systems, assuming a $100 \mathrm{lb} / \mathrm{sq} \mathrm{ft}$ design live load, is given in Table A3.

A majority of cast-in-place concrete floor slabs are usually 4 to 6.5 in. thick. Reinforcement may be steel bars, but generally is a steel reinforcement mesh. The slab may also be a composite type, in which a metal deck is used as both a form and as a structural element. To ensure that the two materials act together under loading, these composite slabs may also contain metal studs that are welded to the steel decking. These studs will increase the amount of steel, but without the original construction documentation, it is difficult to determine whether the studs exist. Therefore, it is acceptable to generalize the amount of reinforcing steel in a slab. A 4-in. concrete slab contains $0.330 \mathrm{cu} f \mathrm{ft}$ of concrete and $1 \mathrm{lb}$ of reinforcing steel per square foot for short span configurations.

An alternativeconcretefloor or roof system may use precast concreteel ements, such as precast tees, planks, and beams. In this case, the individual elements will need to be added up to find the total volume. Since each building will contain varying amounts of precast materials, the most appropriate estimation method is to A rule of thumb for the volume of concrete for a 6 in. thick hollow core concrete plank is approximately $0.013 \mathrm{cu}$ yd per square foot of plank. The volume of concrete in an $8 \mathrm{ft}$ wide, $18 \mathrm{in}$. deep, “double-tee” precast deck is approximately $0.010 \mathrm{cu}$ yd per

Table A3. Proportionate quantity of concrete in various floor systems.

\begin{tabular}{|c|c|c|c|c|}
\hline \multirow{2}{*}{$\begin{array}{l}\text { Type of Floor } \\
\text { System }\end{array}$} & \multirow[b]{2}{*}{ DLL } & \multirow[b]{2}{*}{ Span } & \multicolumn{2}{|c|}{ Per sq ft of floor area } \\
\hline & & & Concrete & Reinfor. \\
\hline Flat Plate & 100 psf & $\begin{array}{l}15 \mathrm{ft} \\
20 \mathrm{ft} \\
25 \mathrm{ft}\end{array}$ & $\begin{array}{l}0.46 \text { cf } \\
0.71 \text { cf } \\
0.83 \text { cf }\end{array}$ & $\begin{array}{l}2.14 \mathrm{lb} \\
2.72 \mathrm{lb} \\
3.47 \mathrm{lb}\end{array}$ \\
\hline $\begin{array}{l}\text { Flat Plate } \\
\text { w/Drop Panels }\end{array}$ & 100 psf & $\begin{array}{l}20 \mathrm{ft} \\
25 \mathrm{ft} \\
30 \mathrm{ft}\end{array}$ & $\begin{array}{l}0.64 \mathrm{cf} \\
0.79 \mathrm{cf} \\
0.96 \mathrm{cf}\end{array}$ & $\begin{array}{l}2.83 \mathrm{lb} \\
3.88 \mathrm{lb} \\
4.66 \mathrm{lb}\end{array}$ \\
\hline $\begin{array}{l}\text { Waffle } \\
\text { 30" Domes }\end{array}$ & 50 psf & $\begin{array}{l}25 \mathrm{ft} \\
30 \mathrm{ft} \\
35 \mathrm{ft} \\
40 \mathrm{ft}\end{array}$ & $\begin{array}{l}0.69 \mathrm{cf} \\
0.74 \mathrm{cf} \\
0.86 \mathrm{cf} \\
0.78 \mathrm{cf}\end{array}$ & $\begin{array}{l}1.83 \mathrm{lb} \\
2.39 \mathrm{lb} \\
2.71 \mathrm{lb} \\
4.80 \mathrm{lb}\end{array}$ \\
\hline $\begin{array}{l}\text { One Way } \\
\text { Beam and Slab }\end{array}$ & 100 psf & $\begin{array}{l}15 \mathrm{ft} \\
20 \mathrm{ft} \\
25 \mathrm{ft}\end{array}$ & $\begin{array}{l}0.42 \text { cf } \\
0.54 \text { cf } \\
0.69 \text { cf }\end{array}$ & $\begin{array}{l}1.90 \mathrm{lb} \\
2.69 \mathrm{lb} \\
3.93 \mathrm{lb}\end{array}$ \\
\hline $\begin{array}{l}\text { Two Way } \\
\text { Beam and Slab }\end{array}$ & 100 psf & $\begin{array}{l}15 \mathrm{ft} \\
20 \mathrm{ft} \\
25 \mathrm{ft}\end{array}$ & $\begin{array}{l}0.47 \mathrm{cf} \\
0.63 \mathrm{cf} \\
0.83 \mathrm{cf}\end{array}$ & $\begin{array}{l}2.26 \mathrm{lb} \\
3.06 \mathrm{lb} \\
3.79 \mathrm{lb}\end{array}$ \\
\hline
\end{tabular}


square foot of deck.

For some linear precast members, such as beams, the volume should be computed by the length of the member. For instance, the volume of concrete in a linear foot of a 36 in. deep precast " $T$ " beam, is 0.13 cu yd per linear foot.

Once the horizontal el ements have been estimated the next step is to estimate the quantity of concrete in columns and walls. If the height of the column or wall cannot be determined, a floor-to-floor height is acceptable for this analysis.

According to Means (1994), a round, cast-in-place column that is $12 \mathrm{in}$. in diameter and $10 \mathrm{ft}$ high generally contains $0.029 \mathrm{cu}$ yd of concrete and $6.6 \mathrm{lb}$ of reinforcing steel. A square column, 10-in. square for a $10 \mathrm{ft}$ story contains $0.026 \mathrm{cu}$ yd of concrete and $5.0 \mathrm{lb}$ of reinforcing steel per vertical linear foot of column.

Final calculation should include any other significant concrete elements.

Concrete Masonry. Concrete block is used extensively in building applications over the whole world. I ts low cost, flexibility, durability, and ease of construction makeit one of the most widely used building systems. Concretemasonry walls may be solid, hollow, grout filled, and reinforced with steel, therefore the quantity of materials may vary substantially.

Paving. Another significant use of concrete in building applications is concrete pavers. These pavers aretypically composed of a widerange of materials, including aggregate and colorants, depending on the use and aesthetic goals of their users. The two most typical forms of concrete pavers are either as "brick" or squares.

\section{Salvage Potential}

Reuse of entire concrete masonry units is not recommended because of the decreased porosity of the surface of used units. The pores will have become sealed with mortar, preventing a strong bond from forming.

\section{Recycling Potential}

Broken or crushed CMUs may be used as backfill material, fill, roadbed aggregate, or aggregate for new CMUs. Aggregate made from recycled concrete can also be used in asphalt paving. Recycling concrete saves on disposal fees for concrete contractors, reduces the expenses of buying new gravel and decreases the cost of making asphalt paving material. Recycled concrete can be used for many of the 
applications for which virgin concrete is used, such as foundations or the concrete layer used below the cold and hot mixes on highway bridges.

\section{Material Removal}

The primary challenge in recycling old concrete, is breaking the concrete and separating it from its steel reinforcement. An example of effective steel separation from the concrete was accomplished by a contractor in Illinois who used a 60,000 pound machine with a large steal beam to send vibrations through the concrete. There are several other methods for the removal of concrete:

- $\quad$ hydraullic and pneumatic hammers

- ball and crane

- $\quad$ explosives

- $\quad$ high pressure water jet

- $\quad$ carbon dioxide expansion bursting

- $\quad$ ultrasonic vibrations

- laser

- $\quad$ electromagnetic waves or fields

- microwaves

- $\quad$ low frequency or high frequency currents.

\section{Debris Handling}

All these methods of demolition then require that the concrete be removed and processed. There are two primary approaches to processing concrete: on-site with mobile crushing units or at a processing facility. Figure A2 shows a flow diagram of a processing facility where the scrap concrete is crushed into aggregate. First, the aggregate is conveyed from the crusher to a large el ectromagnet that separates out ferrous metals. The aggregate then passes through a series of screens that separate the material by size into three grades. Aggregate sized at three inches in diameter is classified as Grade A material and is primarily used in foundations. Grade B aggregate is 1.5-in. in diameter and is primarily used for sidewalks and other applications exposed to weather. Grade C aggregate is 3/8-in. in diameter and is used a subbase material (such as for footings in foundations) (Donovan, 1991). 


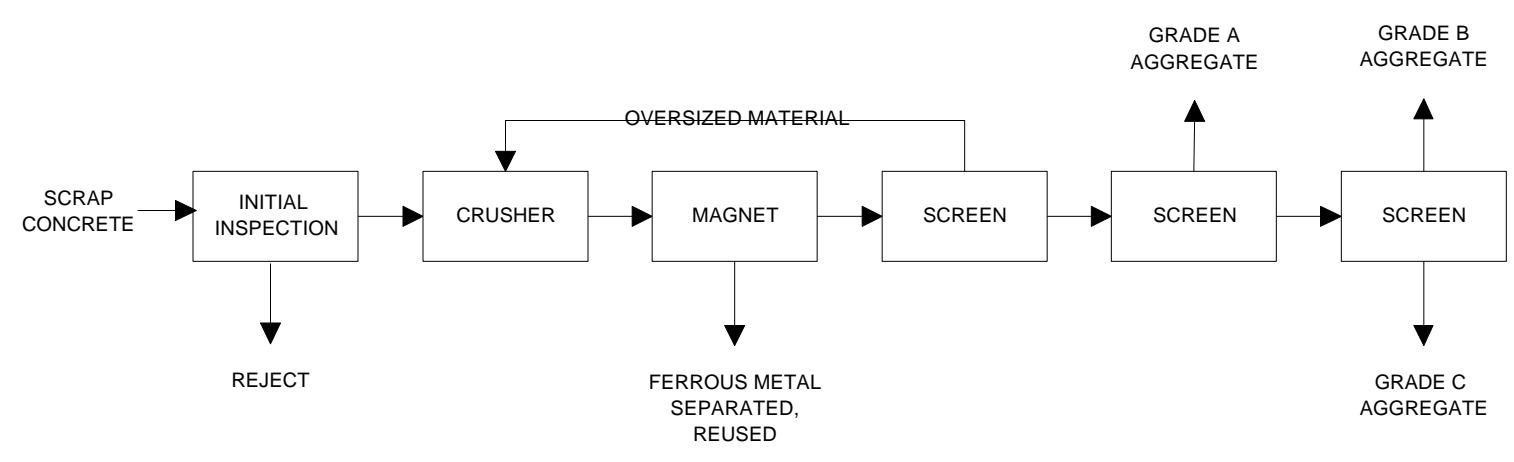

Figure A2. Representative concrete processing plant.

\section{Contaminants}

\section{Characteristics}

In some projects, either the preparation of the site or the demolition of a building will involve the disposal of materials that may be contaminated and, therefore, present special handling requirements according to Army Regulations. Contaminated materials are those that require special handling to minimize the toxicological and environmental hazards in disposal. The types of recyclable contaminants on military installations may include soil that is saturated with motor oil or chemicals, and underground fuel tanks that may contain someresidues of oil or gas. This category may also include empty paint or chemical containers used during construction or renovation as well as lead paint and asbestos. This dass of materials does not include, though, the materials that are classified as hazardous. Hazardous materials are defined in Army TM 5-634 (p 4-121) as "a solid waste or combination of solid wastes, which because of its quantity, concentration, or physical, chemical, or infectious characteristics may: (1) cause, or significantly contribute to, an increase in mortality or an increase in serious irreversible, or incapacitating reversible, illness; or (2) pose a substantial present or potential hazard to human health or the environment when improperly treated, stored, transported, or disposed of, or otherwise managed."

Contaminated materials, such as oil-impregnated soil or fuel tanks, are a common occurrence on military installations. The presence of vehicles, heavy equipment, and other transportation equipment usually indicates the presence of contaminated earth due to fuel leaks or runoff from maintenance activities. These contaminants 
generally are a problem for contractors who are excavating the site or are performing clean up operations. Contaminants will become more of an issue in the future as more military installations are closed under Base Realignment and Closure(BRAC) activities. Many installations must befree of hazardous conditions prior to privatization. Because of the high cost of remediation and disposal, recycling the contaminated materials provides an attractivealternativetodisposal.

\section{Quantity Estimates}

The difficulty in estimating petroleum saturated soil is accurately measuring the quantity of soil that has been contaminated. Typically, a geologist must be called to measure the extent of the contamination. The common unit of measurement for soil is volume. The quantity of fuel containers must be measured by the number of containers and their weight if they are to be scrapped.

\section{Salvage Potential}

The fuel tanks and empty cans and containers may be cleaned and sold for their scrap value if economics warrant this disposition. Used solvents, such as paint thinner and cleaning chemicals can be recycled. In some cases the relatively high cost of disposal in special hazardous material landfills may make for salvaging the materials for their scrap value economically viable.

\section{Recycling Potential}

Therea few recycling options for the two common forms of contaminants, petroleum impregnated soil, and used fuel containers. In the case of soil, it is generally not financially feasible to recover the fuel content of the soil. The soil may be used, though, as fill for paving. There are also a few manufacturers that can use the soil as one component of bricks. The fuel containers can generally be either reused if in good condition, or scrapped for their material content if they are made of steel. Reuse of the containers, particularly large capacity tanks would require recertification if it is to be used again for liquid storage.

\section{Material Removal}

To ascertain whether $C \& D$ debris is hazardous, the debris sample must undergo Toxicity Characteristic Leaching Procedure (TCLP) analysis by a certified laboratory. The results of the analysis are then compared to levels established by the USEPA for certain chemicals. If thelevel in the sample exceeds the established level, the waste is considered hazardous (Ch. 6). 


\section{Debris Handling}

Prior to demolishing a structure, undesirable components should be removed. In most cases, these contaminated materials require special handling or disposal. If the $C \& D$ debris is hazardous, the debris must be properly disposed at a licensed hazardous waste facility.

\section{Fibrous Materials}

\section{Characteristics}

Therearethree groups of fibrous materials used in construction (H ornbostel 1973):

- natural fibers

- regenerated fibers

- $\quad$ synthetic fibers.

Natural fibers includes those fibers that are derived from vegetable, mineral, or animal material. The most common building product use for natural fibers is as textiles, such as canvas or fabrics. Textiles have a number of construction uses, but are mostly included in movable equipment applications such as upholstered furniture, wall coverings, floor coverings, modular office furniture coverings, and window treatments.

Regenerated fibers are synthesized from naturally occurring polymeric materials like glass, proteins, and cellulose. Glass fibers, for example, are used in fiberglass and mineral wool insulation, textiles, and as reinforcements in polymers.

Synthetic fibers are produced from synthetic polymers. This type of fiber includes polyester, nylon, polyethylene and PVC. Most synthetic fibers are used in textiles, carpet, etc.

\section{Salvage Potential}

Scrap carpet can be salvaged and used as landfill cover. 


\section{Recycling Potential}

Carpet has been recycled and used as an additive for recycled plastic lumber. This composite material contains a blend of vinyl, nylon fibers, and post-consumer plastic. Recycled plastic lumber is extruded into a flexible array of configurations induding standard lumber profiles that can be used for picnic tables and decking as well as landscaping timbers.

Old fabric from office workstations can be shredded and made into insulation and carpeting for automobiles (Demkin 1996). Carpet padding made from reclaimed and recycled fibers such as jute, hemp, acrylics and cotton are an excellent use of reclaimed fibers from industrial textile mills and recycled jute and hemp from burlap and rope. Some other products that include recycled fibrous materials are IGLOO containers with 10 to 25 percent post-consumer fiberglass and NAGAWOOD ceiling tiles with 100 percent recycled content - 70 percent postconsumer cellulose fiber, 30 percent recovered plastic.

\section{Glass}

\section{Characteristics}

Most building applications for glass, such as windows, doors, and shelves, are in the form of sheet glass. The most common form of glass found in building applications is designated as silicon-sodium-calcium. From a recycling standpoint, this form of glass is most conducive to reuse, since it will contain (in the form of C\&D waste) the least amount of contamination. The amount of contamination is important because the virgin resources (with the exception of energy) for glass are relatively inexpensive. Removing contamination from glass debris will certainly affect the economics of a recycling operation.

Glass block, corrugate sheets, cellular, structural glazing, which has an opaque coloring, mirrors that have a reflective backing, wire glass and safety glass are less likely to be recycled because of their varying chemical and physical composition.

The possible contaminants found in building glass include the materials used to make weathertight seals between glass and frames: gaskets, foam, adhesives, wood or metal shims, clips, glazing compounds, polybutenetapes, poly elastomers. These are "soft" contaminants that may or may not be removed during processing. Insulated window units may contain other types of contaminants including thealloy 
spacer between the frames and adhesive. The glass may also be adhered to reflective or laminating materials (such as films and coatings).

The most difficult contaminants to deal with are "hard" contaminants including metals, concrete, masonry or clay, and ceramics. These contaminants must be removed mechanically. Metallic particles are the most potentially damaging contaminants to the recycling processes. For example, in fiberglass production, elemental metals are not oxidized in the el ectric melting furnaces and therefore are not dissolved. The molten metal may then collect at the bottom of the furnace and seep through joints in the refractory and make contact with the metal casing of the furnace. Contact with the steel surface of the furnace can cause a ground and shut down the furnace. The extra metal may also cause corrosion to the point that it reduces the life of a furnace (Guter 1992).

\section{Quantity Estimates}

Residential window glass 1/8 in. thick $\quad=165$ $\mathrm{Ib} / \mathrm{sf}$

Commercial plate glass $1 / 4 \mathrm{in}$. thick $=3.28 \mathrm{Ib} / \mathrm{sf}$

Glass block $\quad=18 \mathrm{lb} / \mathrm{sf}$

\section{Salvage Potential}

Windows can be removed during demolition and warehoused in a salvage store. Other businesses and salvage yards buy used windows and doors from contractors and resell them. Salvaged windows are not used in new construction, but odd size windows may be just what the home remodeler is looking for.

\section{Recycling Potential}

At present, only a small amount of waste glass from remodeled and demolished buildings is recycled. In order for it to be used as cullet in the manufacture of new glass, it must be essentially free on nonglass constituents. However, certain types of flat glass can be recycled into glasphalt, an asphalt substitute; glascrete, a concrete substitute; glass aquarium stones; glass beads; and gl ass filler for street curbs and ceramic floor tiles (Demkin 1996). Plate glass form C\&D activities can be used as part of the feedstock for manufacturing fiberglass. Glass accounts for 3$4 \%$ of the material used to produce fiberglass. 
In a septic filtration project recently developed in a cooperative effort by Federal agencies, fifteen tons of discarded glass was crushed and sifted then used as lining for a septic field. The glass is inert and does not attract bacteria as does gravel. Water also flows through glass almost 20 times faster.

\section{Material Removal}

Windows must be carefully removed before demolishing a building if they are to be salvaged. It is labor intensive and not cost-effective unless the windows have value as architectural salvage (Donovan 1992). Once a building has been demolished, it is virtually impossible to salvage the windows. Broken glass cannot be easily separated out and therefore should be removed intact.

\section{Debris Handling}

Various methods have been investigated for the processing of various glass-making wastes to recover valuable components. Crushing, screening, magnetic and other metal separations, gravity separation, and vitrification have all been considered as processes, and all have merit. Multigravity separators may prove to be effective in separating cullet from ceramic fragments because most ceramics are denser than glass. Optical techniques, where infrared light passes through the glass, have been used to detect ceramic contaminants that are opaque to infrared light and will produce shadows. When a contaminant is detected, a trigger sets off a jet of air that blows out the foreign ceramic.

\section{Gypsum/Plaster}

\section{Characteristics}

The principal construction use for gypsum products is in wall board construction. Plaster and gypsum products both have has naturally hydrated calcium sulfate as their principal component. Gypsum $\left(\mathrm{CaSO}_{4} \cdot 2 \mathrm{H}_{2} \mathrm{O}\right)$ is composed of 79 percent calcium sulfate and 21 percent water, and is used as a generic term for all calcium materials. In addition to gypsum, drywall contains several other additives, induding soaps, boric acid, silicone glue, starches, potassium sulfate, fiberglass, chelating agents, water dispersants, and asphalt wax emulsions (Musick, 1992). Due to these contaminants, the use of recycled drywall for anything other than for new drywall, will be limited. 
Wall board waste from construction activities is relatively free of paint, asbestos, or other substances that contaminate demolition wall board over the life of a building. Wall board waste from demolition of buildings may have higher contaminant levels because of earlier manufacturing processes (asbestos for example) and paint, wall paper and other substances that may have come in contact with the wall lboard over the life of the building.

Occasionally, gypsum is also used in the form of building blocks for fire proofing. These light weight, fire resistant blocks sometimes have, in the past, included asbestos or vegetable fibers.

\section{Quantity Estimates}

The industry rule of thumb is that drywall scrap will equal $1 \mathrm{lb} / \mathrm{sq} \mathrm{ft}$ of floor area, or about 1 ton per average house. According to Architectural Graphic Standards (Hoke, ed. 1988), material take-offs can be calculated using the following conversions:

Examples:

$$
\begin{aligned}
& 1 / 2 \mathrm{in} . \text { gypsum wall board }=2 \mathrm{lb} / \mathrm{sf} \\
& \text { plaster on wood lath }=8 \mathrm{lb} / \mathrm{sf}
\end{aligned}
$$

One linear foot of an 8 foot tall interior partition [(1 lf $)(8 \mathrm{ft})=8 \mathrm{sf}]$, gypsum wall board both sides:

$$
2(2 \mathrm{lb} / \mathrm{sf})(8 \mathrm{sf})=32 \mathrm{lbs}
$$

One linear foot of an 8 foot tall interior partition ( $8 \mathrm{sf}$ ), plaster on both sides:

$$
2(8 \mathrm{lb} / \mathrm{sf})(8 \mathrm{sf})=128 \mathrm{lbs}
$$

\section{Salvage Potential}

Both construction and demolition drywall can be salvaged or recycled. When hanging drywall in new construction and remodeling, larger scraps should be set aside for use where filler pieces are needed, e.g., in closets. 


\section{Recycling Potential}

Plaster wastefrom remodeling or demolition is generally not being recycled because of the problem of distinguishing gypsum plaster from lime plaster in the waste stream, the difficulty in separating plaster from lathing and stud material, and the lack of clearly identified products into which the waste can be recycled. However, new technologies exist which will change this in the future. When paint and other coverings are not present, waste gypsum wallboard can be recycled into new wallboard. Virgin gypsum has long been used as a soil amendment in different parts of the country. Crop-growing tests have shown that drywall applied as a soil amendment in specified amounts benefited crops (Goddard 1994). Processes are also being devel oped totransform waste drywall into animal bedding and fertilizer.

\section{Material Removal}

Scrap gypsum from construction projects should be sourceseparated at the site and stored in separated marked containers for drywall waste only. Care should be taken not to mix the drywall waste with other $C \& D$ debris because if the gypsum is contaminated, it may not be able to be recycled.

\section{Debris Handling}

There are several firms in North America known to be actively processing waste drywall. Figure A3 shows the flow of drywall waste through a representative gypsum processing plant. Relatively homogeneous drywall waste is processed into a fine powder that is then sold back to the manufacturers of wallboard. Other companies have developed the technol ogy to separate the paper from the gypsum. This paper is either sold to a paper mill or recycled into backing paper. 


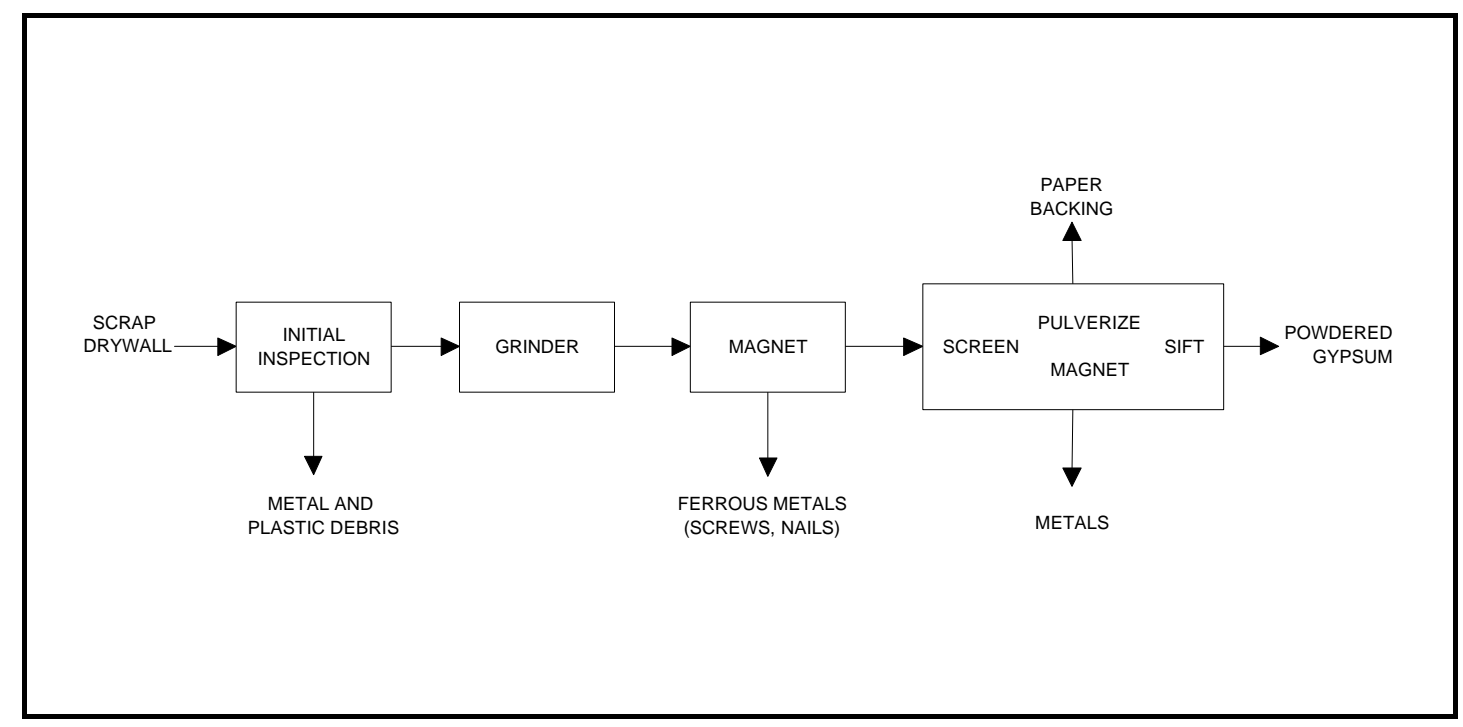

Figure A3. Flow of drywall waste through a representative gypsum processing plant.

\section{Metal, Ferrous}

\section{Characteristics}

Metals that are designated as ferrous are those that contain iron. This includes all iron-based alloys such as: cast and wrought iron, steel, stainless steel, super steels, and weathering steels.

Steel. The term steel usually refers to plain carbon steels that do not contain more than 2 percent carbon. The physical composition of construction steels varies considerably, according to its applications. For example, some steels are more corrosion resistant than others. The most prevalent form of steel used in buildings is mild, structural grade steel, which is characterized by 0.15 to 0.29 percent carbon. Some typical construction applications for this type of steel include:

- $\quad$ structural steel

- ornament

- $\operatorname{rod}$

- $\quad$ reinforcing rod

- windows

- $\quad$ mesh, including fencing

- $\quad$ corrugate and rolled sheets

- doors

- fasteners. 
Machinery steel, i.e., that which may be found in large building equipment, usually contains 0.25 to 0.35 percent carbon.

Steel may be finished in a number of ways, such as painted or galvanized. Galvanizing represents somewhat of a problem for recycling, since once removed, it is considered a hazardous material. Applications where the steel will have some substantial finish are: roofing, siding, decking, and dadding.

Stainless Steel. The stainless steel alloys used in construction generally contain more than 10 percent chromium. Stainless steel is more resistant to heat, oxidation, and corrosion than typical Table A4. Steel joist weights.

\begin{tabular}{|c|c|}
\hline Depth (in.) & Weight (Ib/lf) \\
\hline 8 & 4.2 \\
\hline 10 & 5.1 \\
\hline 12 & 6.2 \\
\hline 14 & 7.6 \\
\hline 16 & 8.9 \\
\hline 18 & 9.8 \\
\hline 20 & 10.2 \\
\hline 22 & 10.8 \\
\hline 24 & 11.5 \\
\hline
\end{tabular}

carbon steels. I ts uses are varied, but are primarily concentrated in exterior uses such as doors windows, trim, grilles, flashing, etc. It is also extensively used in kitchens, bathrooms and laboratories.

Cast Iron. Cast iron is an iron alloy that contains more than 1.7 percent carbon. Its relatively high carbon content increases its compressive strength, but also makes it more brittle. Its primary uses in construction have been in pipes and fittings, enabled plumbing fixtures, and miscellaneous details.

\section{Quantity Estimates}

According to AISC Manual of Steel Construction, a linear foot of $1 \mathrm{in}$. diameter steel pipe, for example, weighs $1.68 \mathrm{lb} / \mathrm{ft}$. A 4 in. steel pipe weighs $10.79 \mathrm{lb} / \mathrm{ft}$. Steel HVAC ducts must be converted to weight measurements by first estimating the total square footage of the ducts. Steel joist weights can be found in Table A4.

\section{Salvage Potential}

There is an active scrap metal market throughout the United States. The actual price depends upon the quality of the materials including such factors as the type of ferrous metal or alloy, the degree of contamination with nonferrous material, the mixing of different types of ferrous metal in one batch and the physical form of scrap for ease of handling and processing (SWANA 1993). 


\section{Recycling Potential}

Magnetic separation makes steel one of the easiest and most economical materials to remove from $C \& D$ waste. As a result, the overall recycling rate of steel products in the United States is about 66 percent, the highest rate of any material. During the past decade, more than 1 trillion pounds of steel scrap have been recycled, extending the life of the nation's landfills by more than threeyears (Demkin 1996). Iron and steel including banding from wood bundles, nails and other fasteners, galvanized flashing and rooding, as well as re-bar, can be separated and recycled. There are no limitations on the reuse of steel in new products. This steel can either be melted down and made into new products or exported as scrap metal.

\section{Material Removal}

The magnetic property of ferrous metals allows them to be separated from mixed debris with relative ease. In theory, steel fasteners can be separated magnetically from demolition wasteand recycled but these small pieces are often firmly attached to nonsteel building components, making such recycling impractical.

\section{Debris Handling}

Ferrous scrap is processed by means of shears, balers and shredders to produce a product suitable as a raw material in new steel manufacture. Solid material such as steel plate, bars, rail, girders and castings are sheared to a size that can be accommodated by remelting furnaces. Appliances are shredded in machines that separatethe ferrous, nonferrous, and nonmetallic materials. Very light scrap such as drums, cans and roofing iron is usually pressed into bales.

\section{Metal, Nonferrous}

\section{Characteristics}

Thedesignation of metals as nonferrous includes all noniron based alloys. The most common noniron metals found in construction applications are: copper, aluminum alloys, lead, brass, magnesium, etc. Since we depend, as a nation, so heavily on foreign supply of nonferrous raw materials, the relative price of this scrap will continue to warrant diverting these materials from the waste stream.

Copper. Copper is a malleable, nonmagnetic metal that has many construction related uses. Its three most important characteristics; high electrical conductance, 
workability, and corrosion resistance, make it a useful material for a variety of building products. The commonly used copper alloys include high copper alloys (99.3 to 96 percent copper content), brasses (commonly includes zinc, tin, as well as lead, manganese and silicon), bronzes (also includes zinc, tin and other alloys), copper nickels, lead coppers, etc. Copper may be painted, anodized, or left bare to form its own protective coating. Most forms of copper are used in the following applications:

- $\quad$ wire, for electrical components and conductors

- formed/Rolled, for plumbing, HVAC applications

- $\quad$ sheets, for lashing, roofing, gutters, mesh, foil

- ornament, for screens, formed tiles.

Aluminum. Aluminum is a soft, lightweight metal that exhibits a high strength to mass ratio. Like copper it also conducts electricity well and therefore has a wide variety of building uses. The aluminum alloy used most often in commercial construction is an aluminum alloy that may contain copper, manganese, zinc, chromium and nickel. Aluminum alloys may be finished, typically by anodization, mechanical polishing, enameling, painting, or left unfinished. The typical applications for aluminum include:

- $\quad$ sheet, flashing, gutters

- rolled, including structural members

- hardware

- $\quad$ extruded shapes for windows and doors

- molding, ornament, screens

- fasteners

- $\quad$ corrugate (roofing)

- miscellaneous, including poles and tubes

- film, insulation and vapor barriers

Lead. Lead is a heavy, soft metal that has excellent workability and good corrosion resistance. At one point there was a wide range of uses for lead and lead alloys in paints and protective coatings, sheathing, flooring, etc. After the discovery of the toxicity of lead, its use by the construction industry declined significantly. Most military uses for construction that will be found on bases will be:

- $\quad$ sheets, flashing

- rolled, pipes

- $\quad$ extruded, caulking

- bar or wire, electrical components. 


\section{Quantity Estimates}

ASCE 7-95 lists the following minimum dead loads for the following nonferrous metals:
Aluminum: $\quad 170 \mathrm{lb} / \mathrm{cu} \mathrm{ft}$
Brass: $\quad 75 \mathrm{lb} / \mathrm{cu} \mathrm{ft}$
Copper: $\quad 14 \mathrm{lb} / \mathrm{cu} \mathrm{ft}$
Lead: $\quad 710 \mathrm{lb} / \mathrm{cu} \mathrm{ft}$

\section{Salvage Potential}

Aluminum, copper, and brass all have a higher market value than steel. If these metals are mixed with steel, the market price for them becomes lower. It is more economical to separate and market these materials individually.

\section{Recycling Potential}

Aluminum can be recovered, recycled and reused endlessly however, recovery of aluminum from demolition and replacement in the building and construction industry is minimal. Fifteen percent, or 60 million pounds, of all constructionindustry aluminum is recovered (Demkin 1996). Lead chimney flashing can, and should berecycled since it is especially important tokeep lead out of landfills, where it can pollute groundwater.

\section{Material Removal}

M ost of the waste nonferrous metals vary widely in alloy and types. Consequently, careful segregation is necessary to simplify controlled smelting.

\section{Debris Handling}

N onferrous metals once sorted are smelted in furnaces and poured off into molds or billets for use in the extrusion industry. Most secondary aluminum is sold to the foundry industry for die-casting new products or turned into sheets for aluminum cans. Copper and brass are suitable for casting and extruding into bars, rods and tubes. 


\section{Paper/Cardboard}

\section{Characteristics}

Paper and cardboard products consist of mechanically processed cellulose fibers, such as wood or vegetable fibers. I ts readily available raw materials and relatively low production costs have made it the predominant material for lightweight, inexpensive applications. The raw material used in paper products, pulp, is essentially the same for most construction uses. The difference in composition between the various types of paper products is due to the additives included in production to improve its characteristics.

Hornbostel (1973, p 500) describes four categories of use for paper products in construction:

- $\quad$ building materials

- containers and protective coverings

- concrete forms

- $\quad$ paper for administrative and supervisory purposes.

The building materials that are paper or pulp-based typically fall into the following categories:

- fiberboard

- $\quad$ sheathing or roofing paper

- insulation

- felt, including asphalt or other mineral impregnates

- gypsum board.

Most of the paper or pulp-based containers include packaging materials for equipment and materials. These paper products include:

- cardboard boxes or cartons

- wrappers

- bags

- $\quad$ protective paper coverings.

Paper-based concreteformwork is typically laminated sheets of paper and adhesive. These forms may be impregnated or lined with wax, plastic, or silicone. 


\section{Quantity Estimates}

The equivalents for Cardboard waste are $100 \mathrm{Ib} / \mathrm{cu}$ yd; 0.05 tons/cu yd; $20 \mathrm{cu}$ yds/ton.

\section{Salvage Potential}

Large cardboard boxes from appliances and other corrugated containers can be reused on the construction site as storage containers or as intermediate waste containers.

\section{Recycling Potential}

Old corregated cardboard is usually the most marketable material generated from construction sites. Most recyclers do not accept wax coated cardboard or nonpaper packaging materials so these would haveto be separated out. Paper and cardboard can be recycled at paper mills or used for fuel pellets.

\section{Plastics}

\section{Characteristics}

Plastic materials are used for an enormous range of building materials. For almost every component of a building, with the exception of structural and mechanical systems, there is a synthetic, plastic counterpart. Plastics are used for wall finishes, flooring, textiles, roofing, plumbing, siding, furniture, and glazing. In general, there are eight different forms that plastics may take in building products:

- coatings

- flooring

- $\quad$ extruded and molded shapes

- foam

- fibers and textiles

- laminates

- film

- $\quad$ sheets and panels.

Plastic coatings include liquefied plastic or cementitious coatings for masonry, concrete, wood, and roofing materials. These coatings include epoxies, acrylics, polyesters, polyurethanes, and vinyls. 
Plastics are particularly suited for extruded and molded shapes. This includes a wide variety of products including piping and fittings, gaskets, shims, baseboard, weatherstripping, electrical components and fixtures, and furniture. These types of plastics include both thermoplastics such as acrylics, fluorocarbons, polycarbonates, polyesters, polyethylene, and polyvinyls.

Plastic films are used for water proofing, vapor barriers, protective coverings, reflective surfaces, and enclosures. The typical plastics used are fluorocarbons, polyamides, polyesters, polyethylene, polyurethanes, and polyvinyls.

The most prevalent use of plastics in flooring is vinyl resistant flooring. Vinyl resistant flooring either comes in solid vinyl or is a vinyl laminated to another resilient sheet. Vinyl flooring comes in sheets, tiles, and poured terrazzo-style flooring.

Plastic foams are generally used in applications that require thermal insulation. They are typically used in sheet form or laminated with other materials such as plywood and metal to create suitable panels for exterior walls and roofing. The most common insulating materials are made from polyurethane and polystyrene.

Plastic laminates have a variety of uses including counter tops, furniture and wall board/paneling. The plastic sheet is typically adhered to either particle board, plywood, or other fiber sheets.

Plastic sheets and panels are used in some of the applications listed above, but also include glazing materials, panels, and roof membranes. Glazing and panel materials are made of acrylics, polycarbonates, polyesters, and polystyrene. Most of these materials can be transparent, translucent, colored, opaque, or patterned.

\section{Salvage Potential}

PVC piping, vinyl siding, and polystyrene packaging may be marketed if they are clean and generated in fairly large quantities. Plasitc film is difficult to market because of the many different types of plastic used to make the various grades of plastic film (Illinois DCCA 1997). Check with your municipal solid waste office to find out what your recycling options are. 


\section{Recycling Potential}

Plastics recovered from $C \& D$ waste can be separated, cleaned and reformed into plastic lumber, highway barriers and traffic cones. Plastic laminates are almost unrecyclable because they are a composite material with thermosetting resins. However, thermosetting resins are increasingly being reground and used as filler in new resin applications. Plastics that cannot be easily separated by type are being processed as mixed plastic waste. If the material is not suitable for plastic lumber, it is being converted into chemicals and fuel.

\section{Material Removal}

Waste materials should be separated and stored where they will stay relatively clean. The plastic industry typically imprints packaging or consumer products with information describing the particular resin used in the plastic. Plastic collected and separated by resin type has a higher market value and demand compared to commingled plastic. There are a few plastic building materials that can be separated by resin type for which potential market exist. PVC and vinyl siding are examples of $C \& D$ waste that has a high potential for separation and recycling.

\section{Debris Handling}

Advanced plastic recycling technologies have continued to mature. Recovered plastic components of virtually any kind are broken down into monomers that can beturned intonew polymer resins for feedstock (Fickes 1997). Figure A4 shows the process for the mechanical recycling of plastics. Plastics are collected and separated by resin type. The plastics are cleaned and regrinded into pellets. These pellets are used as feedstock for the fabrication of recycled plastic lumber products.

\section{Soil}

\section{Characteristics}

Soil is comprised of solid grain material, including gravel, sand and silts, water, air, and organic material including organisms, peat, and plant material.

Depending on the project, soil stones and clay can be a large proportion of the materials from the demolition and construction site.

Soils may be contaminated by previous site uses including refinery and petroleum storage facilities, sites with metal processing and metal recycling histories, and manufactured gas and coal or coke processing and storage sites. 
Quantity Estimates

Earth, dry and packed $\quad 95 \mathrm{lb} / \mathrm{cu} \mathrm{ft}$

\section{Salvage Potential}

In a project where the waste material is likely to be soil, such as the development of a new road, all of the recovered material can in principle be reused on site. Soil can be also be reused in landscaping applications or for landfill cover.

\section{Recycling Potential}

Soil contaminated with petrol eum products and other hazardous materials such as lead, arsenic, cadmium, and zinc can be stabilized and recycled. The soil can be mixed with gravel and used as fill or paving material.

\section{Material Removal}

Most site, land clearing, and foundation activities include gathering or collecting soil since it is difficult segregate the soil from any intended material with heavy equipment.

\section{Debris Handling}

A screening process separates fine soil from mixed rubble. In a two stage process, commingled rubble is first raked to separate out large contaminants and then mechanically sieved to produce a fine soil product. If excavation generates petroleum contaminated soil, special handling, processing and/or disposal is required.

\section{Treated Wood}

\section{Characteristics}

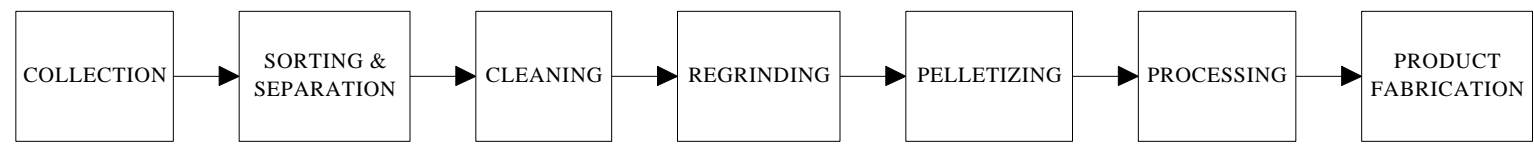

Figure A4. Process for mechanical recycling of plastics. 
Wood has been used for construction for thousands of years. It has been used in all facets of buildings, includingstructural systems, furniture, wall coverings, cabinets, etc. Its prevalence for military installation is due to the fact that most Army barracks were constructed in dimensional lumber. The physical and chemical properties of wood varies widely, though, making it a difficult category of material to classify. This problem is compounded by the dozens of methods in which the wood is treated. This report has classified wood into two categories: treated and untreated.

Donovan (1992, p 4) used three categories to define treated wood:

- $\quad$ surface-coated with paints, stains, and coatings

- $\quad$ manufactured with glues and binders

- $\quad$ impregnated with preservatives.

The largest quantity of treated wood used in construction has been surface-coated. Most wood species require some protection against moisture or are finished to enhance its aesthetic qualities. This includes painting or finishing the wood with either solvent or water based finishes. It also includes wood laminated with plastics.

Wood products manufactures with glues and binders include plywood, laminated wood, particle board, and oriented strand sheathing. Wood that has been impregnated with preservatives includes moisture and insect resistant lumber treated with creosote pentachlorophenol, or chromated copper arsenate.

\section{Salvage Potential}

The salvage potential for treated wood is not as high as that for untreated wood. The treatments on the wood usually have to be removed before that can be reused i.e. stripping paint. Other wood products that can be salvaged in renovations and demolitions include cabinets, flooring, siding, doors, structural components, and dimensional lumber. These items havea resal evalue and are typically maketed for reuse at a fraction of the comparable new product prices. Resale requires a large storage area or warehouse for the goods as well as a knowledgeable sales staff and sufficient publicity to draw potential customers from the public (Goddard 1994). Scarcity of traditional building materials and a perceived reduction in quality have increased the interest in salvaging materials. 


\section{Recycling Potential}

Wood treated with coatings such as paint can be classified as hazardous material if the paint contains lead. This is also true for lumber treated with preservatives. All coatings must first be removed before the wood can be recycled. End-use markets for wood include landscaping mulch, boiler fuel and animal bedding.

\section{Material Removal}

Mechanical demolition leaves a large pile of mixed material out of which the wood must beseparated and processed. Deconstruction or dismantlement al lows thewood to remain separate from other materials and contaminants also salvaging the dimensional lumber for reuse. Removing lumber piece by piece will reduce the structural stability of the building and one needs to be careful of structural failure. Wood products such as cabinets and doors should al so be car efully removed so that they maintain their resale value if they are to be salvaged.

\section{Debris Handling}

Wood waste can be processed in a variety of ways. A mobile chipper can grind the material at the site where the waste is produced. Or, the material can be hauled away to a processing plant that processes waste. Figure $A 5$ shows a representative wood waste processing plant. Specific equipment and material flows will vary among processing facilities (Donovan 1991). Nonwood waste is separated first through source separation by the waste generator or the waste hauler. Some facilities may accept mixed loads of $C \& D$ waste and the separation of nonwood waste would be done at the plant. Separation can be accomplished by loading materials into a flotation tank in which wood material floats and other materials sink.

Next the wood is loaded onto a conveyer belt where it is sorted manually and inspected to remove contaminated wood that should not be processed. The conveyer

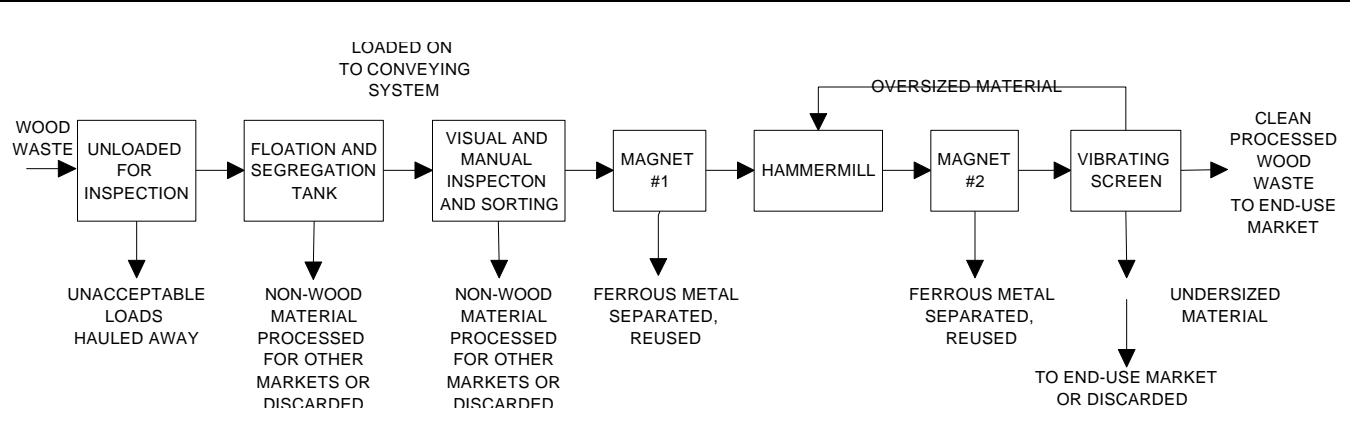

Figure A5. Flow of materials through a representative wood waste processing plant. 
passes a large magnet that separates out metals such as nails, staples and other scrap. From here the wood waste is processed by a hammermill that reduces the multipleshapes and sizes of wood into small, uniform wood chips. A second magnet removes any remaining ferrous material from the wood waste before it passes over a vibrating screen that separates the material according to size.

\section{Untreated Wood}

\section{Characteristics}

Untreated wood is clean wood that contains a minimal amount of nonwood material. Some construction and demolition activities produce wood waste that is free of nonwood materials. The source of this type of wood is the harvested wood materials created in clearing a site, dimensional lumber, pallet wood, and other packaging materials.

\section{Quantity Estimates}

$$
2 \times 4 \text { interior partition 16" O.C. }=4 \mathrm{lb} / \mathrm{sf}
$$

One linear foot of an 8 foot high $2 \times 4$ partition $=(4 \mathrm{lbs} / \mathrm{sf})(8 \mathrm{sf})=32 \mathrm{lb}$

\section{Salvage Potential}

More and more, builders are looking into the use of salvaged lumber. Reclaimed timbers from old buildings often offer wood of species or a quality less readily available otherwise. This salvaged wood can also be used to make furniture. At a construction site, much of the wood waste are cut-offs from dimensional lumber. These smaller lengths of lumber can be used for criples, lintels, and blocking. One way to keep this wood waste separate from other waste is to make all wood cuts at a central location or have a centrally located pile where cut-offs are brought. Bridging, blocking, and backframing lumber can come from this cut-offs pile.

\section{Recycling Potential}

Typically, wood waste is processed and sold to the highest pricemarket. Developing markets include landfill cover and municipal solid waste and sludge composting. If wood products cannot be salvaged they can be chipped into a feedstock used to create new building materials such as particleboard or medium-density fiberboard (MDF). The specifications for building material feed stock are very stringent since any contamination can affect the final product's performance and appearance. 
Boiler fuel and mulch have less restrictive specifications than building material feedstock since they are degraded through burning or decomposition. Contamination with nonwood materials is prohibited for these products because they can cause pollution problems. One area of great promise for recycled wood is its use in combination with recycled plastics to make useful, high-performance composite products. The possibilities range from complex molded forms for automobileinteriors to packaging, furniture, and housing components. This lumber substitute is also being used in outdoor applications, such as decks, due to its decay resistance.

\section{Material Removal}

As mentioned above, wood that has not be contaminated with coatings or mixed with other $C \& D$ debris will yield a higher value at end markets. Therefore, manual dismantlement of a wooden structure is the best method for removal of this material. Mechanical demolition is also an option. Some recyding facilities accept the mixed $C \& D$, but it is not worth as much. If the wood is to be salvaged and reused as dimensional lumber, all nails and other fasteners will need to beremoved.

\section{Debris Handling}

Untreated wood waste is processed in the same manner as treated wood waste. Figure A4 shows a representative wood processing plant. Most of the raw material requires chipping, grinding, or fiberizing to reducethenonhomogeneous wood waste into a uniform material for processing. By utilizing various sized wood particles generated from the waste stream and hot pressing the particles with adhesive, a variety of panel products such as particle board and MDF can be produced.

Old timber that is to be salvaged and reused as a structural member should be graded by a grading agency. Currently, the only standardized method available for assigning allowable engineering properties to lumber and timbers (lumber greater than 5-in. in thickness) is by using visual grading. Visual grading is based on the premise that the many growth characteristics that exist in timber can be seen and judged by the eye. 


\section{Glossary}

asbestos: Mineral used in construction materials from which fibers may be released, become entrained in the air of the building, be inhaled by an inhabitant, and lodge in the bronchia or lungs. The most common type of asbestos consists of the mineral chrysotile. It is considered the least toxic of the asbestos minerals. Less common is a group of amphibole minerals. The amphiboles occur in nature both as fibrous and as nonfibrous varieties. All the fibrous varieties are regulated by both the USEPA and OSHA. The nonfibrous varieties of the amphiboles are not regulated. The fibrous amphiboles are considered to be more toxic than chrysotile, and are more likely to become airborne, due to their brittleness and shorter fiber length.

base realignment and closure (BRAC): A process directed by Federal law to mandate closure, consolidation, and realignment of defense installations.

bid-award contract: Award of the contract shall be made by the owner to the lowest, qualified bidder whose proposal conforms to the cited requirements of the owner.

construction: The erection, installation, or assemble of a new facility; the addition, expansion, extension, alteration, conversion, or replacement of an existing facility; or the relocation of a facility form one installation to another. Includes equipment installed and made part of such facilities, and related site preparation, excavation, filling and landscape, or other land improvements.

construction/demolition waste: The waste building materials, packaging, and rubble resulting from construction, alteration, remodeling, repair, and demolition operations on pavements, houses, buildings, and other structures.

deconstruction: Manual dismantling of a building.

demofill: Landfill for construction and demolition waste only. 
demolition: The removal of existing structures and utilities as required to dear the construction site. The removal of the facilities proposed for destruction in the justification for the new construction.

ferrous: Metals containing iron.

friable: Crumbles under hand pressure; used to describe asbestos.

hazardous waste: A solid waste, not specifically excluded from the restrictions of Federal regulations, that meets the criteria listed in 40 CFR part 261 or is specifically named as a hazardous waste in Federal regulations.

leachate: Liquid that has percolated through solid waste and has extracted dissolved or suspended materials from it.

lead-based paint: Paint or other surface coatings that contain lead equal to or in excess of $1.0 \mathrm{mg} / \mathrm{cm}^{2}$ or more than 0.5 percent by weight $(5,000 \mathrm{ppm})$.

municipal solid waste landfill: A discrete area of land or an excavation, on or off an installation, that receives household waste and that is not a land application unit, surface impoundment, injection well, or waste pile. A municipal solid wastelandfill unit al so may receive other types of waste, such as commercial solid waste or industrial waste.

recoverable resources: Materials that have useful physical or chemical properties after serving their original purposes. Recoverable resources can be reused or recycled for the same or for other purposes.

recyclable materials: Materials that normally have been, or would be discarded (such as scrap and waste) and materials that may be reused after undergoing some kind of physical or chemical processing. Recyclable materials may include discarded materials that have undergone demilitarization or mutilation at an installation prior to transfer to the property disposal officefor sale. Recyclable materials do not include -

1. Precious metal-bearing scrap

2. Those items that may be used again for their original purposes or functions without any special processing such as used vehicles, vehicle or machine parts, bottles (not scrap glass), electrical components, and unopened containers of unused oil or solvent. 
recycling: The result of a series of activities by which materials that would become or otherwise remain waste, are diverted from the solid waste stream by collection, separation, and processing and are used as raw materials in the manufacture of goods sold or distributed in commerce or the reuse of such materials as substitutes for goods made of virgin materials.

re-use: The use of a product more than once in its same form for the same purpose.

salvage: Personal property that has some value in excess of its basic material content, but is in such condition that it has no reasonable prospect for use as a unit for the purpose for which it was originally intended, and that its repair or rehabilitation for use as a unit is impracticable.

scrap: Material that has no value except for its basic material content.

solid waste: Solid waste is composed of nonliquid, nonsoluable materials ranging from municipal garbage to industrial wastes that contain complex and sometimes hazardous substances. Solid waste also includes sewage sludge, agricultural refuse, demolition wastes, and mining residues. Technically, solid waste also refers to liquids and gases in containers. 


\section{Abbreviations and Acronyms}

$\begin{array}{ll}\text { ASCE } & \text { American Society of Civil Engineers } \\ \text { BEAC } & \text { Business Environmental Assistance Center } \\ \text { BRAC } & \text { base realignment and closure } \\ \text { C\&D } & \text { construction and demolition } \\ \text { CERCLA } & \begin{array}{l}\text { Comprehensive Environmental Response, Compensation \& } \\ \text { Liability Act }\end{array} \\ \text { CMU } & \text { concrete masonry unit } \\ \text { DA } & \text { Department of the Army } \\ \text { DCC } & \text { Defense Construction Canada } \\ \text { DE } & \text { Directorate of Engineering } \\ \text { DERP } & \text { Defense Environmental Restoration Program } \\ \text { DOD } & \text { Department of Defense } \\ \text { DOT } & \text { Department of Transportation } \\ \text { FPDO } & \text { Defense Property Disposal Office } \\ \text { DRMO } & \text { Defense Reutilization and Marketing Office } \\ \text { USEPA } & \text { U.S. Environmental Protection Agency } \\ \text { FHW } & \text { Fedighway Administration } \\ \text { F } & \end{array}$




\begin{tabular}{|c|c|}
\hline GSA & General Services Agency \\
\hline HMA & hot-mix asphalt \\
\hline HQUSACE & Headquarters, U.S. Army Corps of Engineers \\
\hline HVAC & heating, ventilation, and air-conditioning \\
\hline IDOT & Illinois Department of Transportation \\
\hline IRP & Installation Restoration Program \\
\hline ISWM & Integrated Solid Waste Management \\
\hline J AG & J udge Advocates's Office \\
\hline LBP & lead-based paint \\
\hline MCA & Military Construction, Army \\
\hline MRF & materials recovery facility \\
\hline MSW & Municipal Solid Waste \\
\hline NADC & The National Association of Demolition Contractors \\
\hline NAHB & National Association of Home Builders \\
\hline NEPA & National Environmental Policy Act \\
\hline NESHAP & National Emission Standards for Hazardous Air Pollutants \\
\hline OSHA & Occupational Safety and Health Administration \\
\hline PCB & Polychlorinated Biphynel \\
\hline ppm & parts per million \\
\hline PVC & polyvinyl chloride \\
\hline RAP & recycled asphalt pavement \\
\hline
\end{tabular}


RCRA Resource Conservation and Recovery Act

SIC

Standard Industrial Code

SWANA

The Solid Waste Association of North America

SWDA

Solid Waste Disposal Act

TCLP

Toxicity Characteristic Leaching Procedure

USACERL

U.S. Army Construction Engineering Research Laboratories 